\title{
DE88 011804
}

\section{GEOTHERMAL ENERGY TECHNOLOGY: ISSUES, R\&D NEEDS,} AND COOPERATIVE ARRANGEMENTS

\author{
Prepared by the \\ Committee on Geothermal Energy Technology \\ Energy Engineering Board \\ Commission on Engineering and Technical Systems \\ National Research Council
}

\section{DISCLAIMER}

This report was prepared as an account of work sponsored by an agency of the United States Government. Neither the United States Government nor any agency thereof, nor any of their employees, makes any warranty, express or implied, or assumes any legal liability or responsibility for the accuracy, completeness, or usefulness of any information, apparatus, product, or process disclosed, or represents that its use would not infringe privately owned rights. Reference herein to any specific commercial product, process, or service by trade name, trademark, manufacturer, or otherwise does not necessarily constitute or imply its endorsement, recommendation, or favoring by the United States Government or any agency thereof. The views and opinions of authors expressed herein do not necessarily state or reflect those of the United States Government or any agency thereof. 


\section{DISCLAIMER}

This report was prepared as an account of work sponsored by an agency of the United States Government. Neither the United States Government nor any agency Thereof, nor any of their employees, makes any warranty, express or implied, or assumes any legal liability or responsibility for the accuracy, completeness, or usefulness of any information, apparatus, product, or process disclosed, or represents that its use would not infringe privately owned rights. Reference herein to any specific commercial product, process, or service by trade name, trademark, manufacturer, or otherwise does not necessarily constitute or imply its endorsement, recommendation, or favoring by the United States Government or any agency thereof. The views and opinions of authors expressed herein do not necessarily state or reflect those of the United States Government or any agency thereof. 


\section{DISCLAIMER}

Portions of this document may be illegible in electronic image products. Images are produced from the best available original document. 
NOTICE: The project that is the subject of this report was approved by the Governing Board of the National Research Counc11, whose members are drawn from the councils of the National Academy of Sciences, the National Academy of Engineering, and the Institute of Yedicine. The members of the committee responsible for the report were chosen for their special competences and with regard for appropriate balance.

This report has been reviewed by a group other than the authors according to procedures approved by a Report Review Committee consisting of members of the National Academy of Sclences, the National Academy of Engineering, and the Institute of Medicine.

The National Academy of Sciences is a private, nonprofit, self-perpetuating society of distinguished scholars engaged in scientific and engineering research, dedicated to the furtherance of science and technology and to their use for the general welfare. Upon the authority of the charter granted to it by the Congress in 1863, the Academy has a mandate that requires it to advise the federal government on scientific and technical matters. Dr. Frank Press is president of the National Academy of Sciences.

The National Academy of Engineering was established in 1964, under the charter of the National Academy of Sciences, as a parallel organization of outstanding engineers. It is autonomous in its administration and in the selection of its members, sharing with the National Academy of Sciences responsibility for advising the federal government. The National Academy of Englneering also sponsors engineering programs almed at meeting national needs, encourages education and research, and recognizes the superior achievements of engineers. Dr. Robert M. White is president of the National Academy of Engineering.

The Institute of Medicine was established in 1970 by the National Academy of sclences to secure the services of eminent members of appropriate professions in the examination of policy matters pertaining to the health of the public. The Institute acts under the responsibility given to the National Academy of Sciences by its congressional charter to be an advisor to the federal government and, upon its own initiative, to identify issues of medical care, research, and education. Dr. Samuel 0 . Thier is president of the Institute of Medicine.

The National Research Council was organized by the National Academy of Sciences in 1916 to associate the broad community of science and technology with the Academy's purposes of furthering knowledge and advising the federal government. Functioning in accordance with general policles determined by the Academy, the Council has become the principal operating agency of both the National Academy of Sciences and the National Academy of Engineering in providing services to the government, the public and the Institute of Medicine. Dr. Frank Press and Dr. Robert White are chairman and vice-chairman, respectively, of the National Research Council.

This is a report of work supported by Contract No. DE-FG01-86CE31010 between the U.S. Department of Energy and the National Academy of Sclences.

Copies available from:

Energy Engineering Board Commission on Engineering and Technical Systems

Nationa1 Research Council

2101 Constitution Avenue, N.W.

Washington, D.C. 20418 


\section{COMMITTEE ON GEOTHERMAL ENERGY TECHNOLOGY}

NORMAN HACKERMAN (Chairman), Sclentiflc Advisory Board, The Robert

A. Welch Foundation, Houston, Texas

JAMES B. COMBS, Geothermal Resources International, San Mateo, California

MYRON H. DORFMAN, Department of Petroleum Engineering, University of

Texas, Austin, Texas

WILFRED A. ELDERS, Institute of Geophysics and Planetary Physics,

University of California, Riverside, California

STEPHEN J. GAGE, MIdwest Technology Development Institute,

St. Paul, Minnesota

ROBERT G. LACY, San Diego Gas \& Electric; San Diego, California

CAREL OTTE, Unocal Corporation, Los Angeles, Galifornia

MARTIN ROBBINS, Colorado School of Mines, Golden, Colorado

JEFFERSON W. TESTER, Massachusetts Institute of Technology, Cambridge, Massachusetts

ERIC A. WALKER, The Pennsylvania State UnIversity, University Park Pennsylvania (retired)

\section{Liaison with Energy Engineering Board}

WILLIAM R, GOULD, Southern California Edison Company, Rosemead, California

\section{Staff}

DENNIS F. MILLER, Director, Energy Engineering Board

JAMES J, ZUCCHETTO, Senfor Program Officer, Committee on Geothermal

Energy Technology

DRUSILLA E. ALSTON, Administrative Secretary 


\section{ENERGY ENGINEERING BOARD}

JOHN A. TILLINGHAST (Chairman), Science Applications International Corporation, San Diego, California

DONALD B. ANTHONY, Standard Ofl Research and Development, Cleveland, Ohio

RaLPH C. CAVANagh, Natural Resources Defense Counc1l, San Francisco, California

THELMA ESTRIN, University of California at Los Angeles, Los Angeles; California

CHARLES F. GAY, Arco Solar, Chatsworth, California

WILLIAM R. GOULD, Southern California Edison Company, Rosemead, California

S. WILLIAM GOUSE, Mitre Corporation, McLean, Virginia

NICHOLAS J. GRANT, Massachusetts Institute of Technology, Cambridge, Massachusetts

JOSEPH M. HENDRIE, Brookhaven National Laboratory, Upton, New York

WILLIAM W. HogaN, Harvard University, Cambridge, Massachusetts

ARTHUR E. HUMPHREY, Center for Molecular Blosclence and Blotechnology; Bethlehem, Pennsylvania

BAINE P. KERR, Pennzoil Company, Houston, Texas

HENRY R. LINDEN, Gas Research Institute, Chicago, I11inois

THOMAS H. PIGFORD, University of California, Berkeley, California

ADEL F. SAROFIM, Massachusetts Institute of Technology, Cambridge, Massachusetts

MAXINE L. SAVITZ, Air Research Casting Company, Torrence, California

WESTON M. STACEY, JR., Georgia Institute of Technology, Atlanta, Georgia

RICHARD STEIN, The Stein Partnership, New York, New York

THOMAS E. STELSON, Georgla Institute of Technology, Atlanta, Georgia

LEON STOCK, University of Chicago, Chicago, Illinols

GEORGE S. TOLLEY, University of Chicago, Chicago, I1linois 
DAVID C. WHITE, Massachusetts Institute of Technology, Cambridge, Massachusetts

RICHARD WILSON, Harvard University, Cambridge, Massachusetts

BERTRAM WOLFE, General Electric Corporation, San Jose, California

\section{Technical Advisory Panel}

HAROLD M. AGNEW, GA Technologies, Solana Beach, California

FLOYD L. CULLER, JR., Electric Power Research Institute, Palo Alto, California

KENT F. HANSEN, Massachusetts Institute of Technology, Cambridge, Massachusetts

MILTON PIKARSKY, The CIty College, New York, New York

CHAUNCEY STARR, Electric Power Research Institute, Palo Alto, California

HERBERT H. WOODSON, The University of Texas at Austin, Austin, Texas

\section{$\underline{\text { Staff }}$}

DENNIS F. MILLER, Director*

JOHN M. RICHARDSON, Acting Director**

ROBERT COHEN, Senior Program officer

FREDERIC MARCH, Senior Program Officer

PATRICK RAPP, Program officer

JAMES J. ZUCCHETTO, Senior Program officer

* Resigned November 9, 1987

**Appointed November 9, 1987 
. 
With some assurance, it is anticipated that the long-term trend in U.S. petroleum reserves and production will be one of decline. The low cost of petroleum in 1987 has resulted in a decline of U.S. Oll production and exploration. Consequently, petroleum imports will 1ikely increase over the next 10 years. Coal is attractive because of large $U . S$. reserves, but its use would have significant environmental effects if cost-effective, clean, coal-burning technologies are not developed. Even with reduced sulfur and nitrogen oxide emissions, coal combustion--1ike combustion of other fossil fuels--adds carbon dioxide to the atmosphere, possibly causing climatic changes and global warming. Though more than $100 \mathrm{U} . \mathrm{S}$. nuclear power plants provide a significant fraction of the nation's electricity, we have no assurance that additional nuclear power plants will be built here. Given these uncertainties about future energy supply, continuing the development of various energy technologies that may become commercial is necessary. One geothermal energy technology is already commercial in the United States, and other forms of the technology are possible energy sources.

The study leading to this report responded to a request to the National Research Council's Energy Engineering Board by the Department of Energy's (DOE) Geothermal Energy-Technology Program, The main study tasks were to review the DOE geothermal program, identify principal issues in the geothermal energy fleld, and suggest possible cooperative arrangements among government, Industry, and universities to faciliate research and development (see Appendix A). The Committee on Geothermal Energy Technology, formed in 1986, first met in December 1986. At this meeting, Dr. John E. Mock, DOE's Geothermal Technology Program director, briefed the committee. A workshop and meeting on February 9 to 11, 1987 (see Appendix B) focused on geothermal energy research and development and on related cooperative arrangements. The committee drafted its report in a working session. 
The committee thanks Dennis Miller, former Director of the Energy Engineering Board, for his development of the study; Dr. James J. Zucchetto, Senior Program Officer, for his useful management and support In all study phases and for preparation of the final report from the rough drafts of the committee; and all workshop participants who provided valuable information and analysis. Heartfelt thanks also go to Drusilla Alston for her administrative support.

Norman Hackerman

Chairman 
1 TECHNICAL SUMMARY 1

The U.S. Energy Situation and Geothermal Resources 1 Costs of Geothermal Power 3 Nonprice Constraints 3

The DOE Geothermal Energy Technology Program 4 Cooperative Arrangements 5 Conclusions and Recommendations 6

2 ISSUES, R\&D NEEDS, AND THE DOE PROGRAM 9

General Considerations 9

Current Status of the DOE Program 17

$\begin{array}{ll}\text { Hydrothermal Resources } & 17\end{array}$

Geopressured Geothermal Resources $\quad 27$

Hot Dry Rock Geothermal Resources $\quad 32$

Magma Energy Resources $\quad 38$

Discussion, Conclusions, and Recommendations 41

3 GOVERNMENT, INDUSTRY AND UNIVERSITY COOPERATION

IN GEOTHERHAL RESOURCE DEVELOPMENT $\quad 47$

$\begin{array}{ll}\text { Background } & 47\end{array}$

Examples of Cooperative Relationships $\quad 49$

Questions About Cooperative Relationships 51

Criteria for Success in Cooperative Relationships 52

Alternative Approaches to Cooperative Relationships 53

Conclusions and Recommendations $\quad 57$

APPENDIX A STATEMENT OF TASK $\quad 59$

APPENDIX B GEOTHERMAL ENERGY WORKSHOP: R\&D AND COOPERATIVE
ARRANGEMENTS

APPENDIX C CONVERSION TECHNOLOGIES FOR POWER GENERATION 67

Dry Steam System $\quad 67$

Single and Double Flash Systems $\quad 67$

Binary Cycle System $\quad 69$

APPENDIX D GENERIC DEVELOPMENT NEEDS 73

Uncertainties in Locating and Characterizing
Reservoirs

High Drilling Costs 73

Corrosion Prevention and High Drilling Costs $\quad 74$

Lack of Efficlent Components: Downhole Pumps
and Instrumentation

Injection Technology for Economic Disposal
of Spent Brines

Conversion Technology 75 
APPENDIX E BACKGROUND INFORMATION

Historical Perspective of the Geothermal Program 77

Private and Public R\&D Efforts

APPENDIX F INVENTORY OF GEOTHERYAL POWER PLANTS

81

APPENDIX G RENEWABLE ENERGY PROGRAM REVIEW

APPENDIX H UNIT CONVERSION TABLE 


\section{TABLES}

2-1 Budget History of the DOE Geothermal Technology Program

2-2 Committee Budget Recommendations for Hydrothermal

Development in the DOE Geothermal Technology Program

2-3 Committee Budget Recommendations for DOE HDR Resource Research and Development

2-4 Committee Budget Recommendations for DOE Magma Energy Research and Development

2-5 Committee Estimates of the DOE Budget Needs for Geothermal Resources Research and Development

F-1 Geothermal Power Plants at The Geysers, California

F-2 Geothermal Power Plants in the Imperial Valley, California

F-3 Geothermal Power Plants in the United States

F-4 Geothermal Power Plants on Line Worldwide as of 1986 


\section{FIGURES}

2-1 Geothermal Technology Cost Relationships.

2-2 Estimates of Electricity Costs with 011 at $\$ 18.50$ per Barrel.

2-3 Estimates of Electricity Costs with 011 at $\$ 28$ per barrel.

3-1 Program Control of Cooperative R\&D Organizations.

C-1 Schematic Diagram of a Dry-steam System.

C-2 Schematic Diagram of a Single Flash System. 70

C-3 Schematic Diagram of Binary Cycle System.

71 


\section{EXECUTIVE SUMMARY}

In 1986, the National Research Council, through its Energy Engineering Board, formed the Committee on Geothermal Energy Technology. The committee's study, sponsored by the Department of Energy's (DOE) Geothermal Technology Program, addressed major issues in geothermal energy technology, made recommendations for research and development (R\&D), and considered cooperative arrangements among government, Industry, and universities to facilitate R\&D under current severe budget constraints. Funding for the Geothermal Technology Program has decreased from a high of about $\$ 158$ million in fiscal year 1979 to $\$ 21$ million in fiscal year 1987. In addition, current (1986-87) low petroleum prices have led to stagnation of the U.S. geothermal industry. These low prices have affected development of alternative technologies, such as for solar energy use and for conservation, and have led to a decrease in domestic petroleum production. Decreased production will most 1ikely increase dependence of the U.S. economy on petroleum Imports over the next decade. The committee believed that the current low prices of hydrocarbon fuels, espectally of petroleum, is a short-term phenomenon within a long-term trend toward rising prices driven by a rising demand and limited supply of lower-cost resources. Given this scenario, it is necessary for the United States to maintain some energy supply options over the coming decades, many of which are now only marginally economic. Because of the large U.S. geothermal energy base, and the possibility of converting even a small part of this resource into economically useful energy, the committee concluded that the development of U.S. geothermal resources at competitive prices could be an important contribution to U.S. energy self-sufficiency.

The report addresses four types of geothermal energy: hydrothermal, geopressured, hot dry rock, and magma systems. Hydrothermal systems are the only type that are now economically competitive commercially. Further technology development by DOE could make the uneconomical hydrothermal resources commerclally attractive to industry. The economics are more uncertain for the longer-term technologles for extracting energy from geopressured, hot dry rock, and magma systems. For some sites, the cost of energy derived from geopressured and hot dry rock systems is projected within a commercially competitive range. The use of magma energy is too far in the future to make reasonable economic calculations. 
For geothermal energy, the location of the resource critically affects the economics. Isolated geothermal fields distant from areas of demand probably cannot be exploited economically. Advances in transmission line technology (such as by using high-temperature superconducting materials) may remove this constraint.

Many environmental effects of hydrothermal systems are judged either to have been solved with environmental control technology or at least to be amenable to solution. Potential environmental problems for geothermal energy use include the possibility of land subsidence from the use of geopressured reservoirs, the disposal of hazardous fluids, and the initiation of microselsmic activity from injecting fluids in wells. Osing geothermal rather than fossil fuel plants would reduce atmospheric loading from oxides of nitrogen and sulfur, carbon dioxide, and particulates. In most cases, such institutional factors as permitting, leasing laws, regulation, and tax treatment would not present insurmountable barriers to geothermal development.

The committee generally agrees with the Geothermal Technology Program goal: to determine and improve the scientific, engineering, and economic feasibility of using energy from hydrothermal, geopressured, hot dry rock, and magma geothermal resources. Developing hydrothermal resources should receive near-term emphasis by both government and private industry. The technologies developed for this resource will help in developing the longer-term resources of geopressured, hot dry rock, and magma systems.

Significant budget decreases over the last few years in the Geothermal Technology Program have severely affected many R\&D projects. The committee concluded that a somewhat higher and much more stable level of funding is required to accomplish further commerclalization of many hydrothermal resources in the near term and to maintain a viable research program for the longer-term resources (see Chapter 2 and Table 2-5).

Many types of cooperative R\&D efforts among government, industry, and universities were examined by the committee. For geothermal energy development, private industry is currently interested only in investing in the near-term hydrothermal resources, many of which are already commercial and economic. Development of the longer-term resources of geopressured, hot dry rock, and magma systems requires federal funding.

Given the existing state of the geothermal industry and energy economics in the United States, one model of cooperation between government and industry stands out as the most successful approach to short-term geothermal R\&D. This is the cooperative arrangement between the Geothermal Drilling Organization (GDO) and DOE. Its aim is to develop technologies that in the short term will reduce costs for collecting data on (logging), drilling, and completing geothermal wells. The committee recommended that the GDO be restructured and broadened to address $a$ wide range of short- to mid-term geothermal development activities, and be called the Geothermal Development Organization.

For the longer-term geopressured, hot dry rock, and magma resources, in which industry is not investing, the committee recommended that a Geothermal Research Organization (GRO) be established. It would be a cooperative university and government endeavor, composed of researchers interested in the scientific and technical issues of long-term geothermal 
resources. Industry participation would not be required but would be encouraged. The GRO would help coordinate the relatively small number of academic researchers working on these long-term resources and the large number of sclentists working in allied flelds. Informal contacts between the Geothermal Development Organization and the GRO could be maintained through observers at each other's meetings. 


\section{TECHNICAL SUMMARY}

The current worldwide oversupply and low cost of fossil fuel energy have contributed to a significant decline in funding U.S. Department of Energy (DOE) research and development (R\&D) on alternative energy technologies. Affected by this decline in particular is R\&D in geothermal energy technologies. Further, as a direct result of lower fuel prices, private development of geothermal resources has stagnated.

The Committee on Geothermal Energy Technology addressed a number of specific tasks relevant to these issues (see Statement of Task, Appendix A), partially through a workshop to which experts were invited (see Appendix B). This report reviews U.S. geothermal energy goals and DOE's Geothermal Energy Technology Program (GTP), identifies major issues for U.S. geothermal energy R\&D, and suggests approaches for cooperative arrangements among government, industry, and the universities to increase the effectiveness of GTP's limited budget. This chapter summarizes the report, including major conclusions and recommendations. Chapter 2 brlefly describes geothermal energy resources, addresses issues for each type of geothermal energy, and considers required DOE R\&D funding levels for each. Chapter 3 addresses cooperative arrangements among government, industry, and universities for identifying possible new funding approaches for the GTP.

THE U.S. ENERGY SITUATION AND

GEOTHERMAL RESOURCES

In general, there is demand for energy of different types, reflected by the market, and there are long-term national needs that cannot be assessed through considering existing supply/demand conditions because supply can change discontinuously and because national objectives include more than assurance that supply and demand are in good balance. Meeting national needs, such as long-term energy security, requires appropriate government involvement. Long-range energy research in many different areas must be pursued for the nation to respond to and solve its energy problems. Solutions require R\&D supported by government and the private sector on various resources and technologies, including those that are not yet economic. 
The committee seriously considered the low market price of petroleum during 1986-87 and its apparent oversupply in world markets. The committee agreed that the low petroleum price during this period was (1) transitory and would eventually rise, (2) depressing the petroleum industry and domestic petroleum production, and (3) increasing $U . S$. dependence on imported petroleum. Consequently, the nation could suffer an energy crisis in the not too distant future. In addition, low petroleum prices have lessened the economic attractiveness of alternative energy technologies and their development. The geothermal energy industry in the United States has stagnated, and budget cuts at DOE have led to significant declines in the GTP (e.g., from a total budget of $\$ 158$ million in fiscal year 1979 to $\$ 21$ million in fiscal year 1987 [see Chapter 2, especially Table 2-1]).

The resource base for geothermal energy is large. But how much of this resource base can be economically converted into useful energy is uncertain. Given the large amount of energy associated with the resource, the ability to convert even 0.1 percent of the resource into an economically competitive energy form would represent an important contribution to the U.S. energy supply. This report addresses four types of geothermal resources: (1) hydrothermal systems, consisting of accumulations of either water or steam in porous or fractured rocks; (2) geopressured systems with anomalously high fluid pressures below 4,500 m depth; (3) hot dry rock systems, rocks of such low permeablilty that they are described as "dry"; and (4) magma systems, in which lava is contalned in a chamber beneath a volcano. Hydrothermal resources are the most developed, have the greatest application, and are economically competitive. In 1986, all the world's geothermal electric power used either steam or hot water from hydrothermal systems. Of a total world installed capacity of 4,733 MWe (megawatts electric), more than one-third (1,788 MWe) was operating in one field, The Geysers, in Sonoma and Lake Counties, California. Almost all the high- and intermediate-temperature geothermal resources occur in the western states of Alaska, California, Hawa11, Idaho, Nevada, New Mexico, Oregon, Utah, and Washington. However, low-temperature resources, which can potentially be used for space heating and low-temperature industrial applications, occur in these states and elsewhere in the central and eastern states.

Conversion technologies for power generation from hydrothermal systems using dry steam systems, single or multiple flash cycles, and binary cycles are all operating commercially. Given present costs for oll and gas, the generation costs for new capacity at The Geysers are competitive with those of petroleum, coal, and nuclear power plants. However, for other hydrothermal systems to compete, the prices of petroleum and gas would have to be near those of 1985 . DOE could accelerate the commerclalization of hydrothermal resources that are currently uneconomic. Present economics of geopressured, hot dry rock, and magma systems are too 
unfavorable in the near term to attract any industry involvement. If these resources are to be developed, DOE must pursue R\&D of these riskier geothermal energy types as a long-term activity having potentially high returns when the costs of competing energy sources escalate.

\section{COSTS OF GEOTHERMAL POWER}

The economics of geothermal power production have been evaluated for many situations. At the busbar (the power plant switchyard), the cost of electricity from geothermal energy is a function of the rellability of the reservolr and power plant operating as a unit plus the cost of energy. For power plants operating in remote regions, the cost of electricity transmission is also a factor. Technological developments can obviously lower these costs. Vapor-dominated hydrothermal resources are used for power production, and they are economically competitive. Liquid-dominated hydrothermal systems promise to be within the range of the current competitive price of electricity, namely, 50 to $70 \mathrm{mills} / \mathrm{kWh}$ ( 5 to 7 cents $/ \mathrm{kWh}$ ). In addition, many hydrothermal systems are near the economic threshold, so every improvement in technology will make them more attractive. The economic uncertainty of geopressured resources hinges on variations in both the recoverable volume and rate of recovery from the producing sandstone formation. At sites that have large volumes and flow rates, electricity costs are projected at about $60 \mathrm{mills} / \mathrm{kWh}$ for systems that use chemical (methane), hydraulic, and thermal energy. Estimated costs of producing electricity from hot dry rock vary significantly with rock temperature, well depth, and reservolr productivity. For example, assuming reasonable rates of fluid production, the Fenton Hill, New Mexico, site is projected to produce electricity in a commercially competitive range. Too little is known about magma energy resources and technology development to make any reliable economic estimates.

\section{NONPRICE CONSTRAINTS}

Several technologlcal constraints require R\&D to remove these barriers to commercialization. Important technical problems include reservoir characterization, chemical corrosion, drilling, limited availability of lower-cost high-temperature materials, and conversion technologies (see Chapter 2 and Appendix D).

In the early development of geothermal energy extraction and conversion In the United States, there were some serlous environmental concerns, for example, about hydrogen sulfide releases and excessive noise. These problems have been solved to an acceptable degree. But others remain, such as the possibility of land subsidence from exploiting geopressured reservolrs, the disposal of hazardous geothermal fluids, and the initiation of microselsmic activity from injecting fluids into the ground. With the use of hypersaline solutions, the most costly environmental problem facing industry is land disposal of solld wastes that in some cases are considered hazardous. All these problems depend on the site, the particular technologies used, and the prevaling regulatory 
situation. Issues in land use and aesthetics also vary, depending on the site. However, these issues should be placed in perspective. Other kinds of power plants also affect the environment and land use. Fossil fuel power plants are allegedley significant contributors to the problems of acld rain and may be the source of potential global climate change from atmospheric pollutants generated from fossil fuel combustion. Nuclear power plants entail the risk (real or perceived) of potential release of radionuclides. Geothermal power plants would reduce or eliminate these environmental problems associated with fossil and nuclear power plants.

Each of the geothermal resource types tends to be found in certain areas of the United States. If the demand for the energy produced from a given site is not within an economically acceptable distance, the site may not be developed. In the case of heating systems, too great a distance will result in an unacceptably high loss of heat. For electric power, the avallability of transmission lines is important because transmission losses over long distances are significant. This last constraint may be reduced through technological developments in superconducting materials, which have just been demonstrated at temperatures around $100 \mathrm{~K}\left(-173^{\circ} \mathrm{C}\right)$, above that of liquid nitrogen.

Current institutional factors--permitting, leasing laws, regulations, and tax treatment--are not insurmountable barriers to geothermal development, except perhaps in special cases. Of course, these factors might be addressed in such a way that they are made more helpful to geothermal development.

\section{THE DOE GEOTHERMAL ENERGY TECHNOLOGY PROGRAY}

The committee generally agreed with the goal of DOE's Geothermal Technology Program, determining and improving the scientific, engineering, and economic feasibility of using energy from all types of geothermal resources, including hydrothermal, geopressured, hot dry rock (HDR), and magma. HDR R\&D dominates the current budget, accounting for 38 percent of it; geopressured and hydrothermal research account for 19 and 14 percent, respectively. Only about 6.7 percent ( $\$ 1.4$ million) was directed for drilling technology, which cuts across all geothermal technologles.

Development of hydrothermal energy resources, the most technically and economically feasible to exploit, should recelve near-term emphasis by both government and private industry. The short-term goal of R\&D should be to achleve technical improvements in locating, developing, extracting, managing, and converting energy from liquid-dominated hydrothermal reservoirs. These improvements should markedly increase the number of U.S. hydrothermal reservoirs that can be used to produce energy in the near term. At the same time, these technologies are needed to exploit geopressured, HDR, and magma resources commerclally, and they are fundamental subjects for a balanced DOE R\&D program. The longer-term goal of the R\&D effort should be to determine whether geopressured, HDR, and magma energy resources are a feasible option for the future and to provide a technical base for industry's evaluation of their commercial use (specific research for each geothermal resource is delineated in Chapter 2). 
The budget of the GTP has declined from about $\$ 158$ million for fiscal year 1979 to less than $\$ 21$ million for fiscal year 1987 (see Chapter 2, especially Table 2-1). Funding for the major areas of R\&D continues, but the reduced hydrothermal research budget affects important projects significantly. Given both the potential for commerclalizing hydrothermal energy in the near term and the need to maintain a research program for longer-term resources, somewhat higher and stable budget is needed. Stable DOE funding is important to attract and maintain the qualified technical staffs required to develop the technology.

\section{COOPERATIVE ARRANGEMENTS}

Most of the workshop was devoted to examining cooperative R\&D efforts among government, universities, and industry (see Appendix B) in presentations from invited guests and discussions with an advisory group. Given present constrained federal budgets and increased economic competition from abroad, cooperative arrangements should be considered as one mechanism to enhance R\&D productivity, attract funds to given programs, and Increase U.S. economic competitiveness. The Statement of Task (see Appendix A) directed the committee to examine two scenarios for cooperation, one based on the existing DOE program and the other on a program the committee recommended. Differences between these two programs would not affect the nature of cooperative arrangements in any significant way; thus, such a scenario analysis was not considered relevant. However, given the higher budget levels the committee recommended, somewhat more money would be available from industry to participate in hydrothermal research.

Cooperative arrangements among industry, government, and universities have been around for many decades, and they exist in literally thousands of variations, but they may not always be desirable. The committee reviewed several types of cooperative arrangements and examined existing arrangements such as the Microelectronics and Computer Corporation, the Electric Power Research Institute, and the Gas Research Institute. One type of arrangement is industry-Industry cooperation, in which the sources of funds and the primary beneficlary of the research are industry. A second type is industry-university cooperation. Three basic approaches exist: (1) an "Industry affiliates" program in which a number of companies pay modest fees to support limited research programs; (2) industry contracts with universities for specifled research; and (3) companies forming a corporation to support university research. A third type of arrangement is government-university cooperation, ranging from the support of large laboratorles to small contract investigations. A fourth type is government-industry cooperation, such as through government contracts with single companies and arrangements between government agencies and consortia of companies. Further, governmentIndustry-university cooperation is the most complicated, but perhaps the most effective for matters of national importance, which generally require significant outside funding.

The committee reviewed these alternatives, taking into account the present economics of energy in the United States, the impact of current 
economics on the geothermal Industry, and recent changes in tax laws. One model, an example of government-industry cooperation, stood out as an especially successful approach to short-term geothermal R\&D. This is the existing cooperative agreement between the Geothermal Drilling Organization (GDO) and DOE. GDO is open to all organizations and individuals who pay a membership fee. The present objective of GDO is to develop technology that in the short term will reduce costs for drilling, completing, and logging geothermal wells. GDO generally sets research priorities and seeks funding from its members and DOE.

Industry will continue to invest only in near-term exploitable hydrothermal resources. Because hot dry rock, geopressured, and magma energy resources require extensive development and their profitability is too far in the future, industry is not investing in them. However, because of the importance of maintaining various future energy options, R\&D on long-term geothermal resources should be continued. To accomplish this goal, a cooperative relationship could be established through a Geothermal Research Organization (GRO) composed of researchers interested in the scientific and technological issues of long-term geothermal resources: Industry participation in this organization would not be required but should be encouraged. GRO would provide advice to government agencies, develop a research agenda, establish a contract administrator to disburse funds from the government (and private industry if interest developed), and form a Geothermal Coordination Group, which would transfer information between GDO and GRO and speak for the broader interests of those involved in geothermal R\&D. Otherwise, coordination between the GDO and GRO would be informal, possibly through sharing a member or sending observers to each other's meetings.

\section{CONCLUSIONS AND RECOMMENDATIONS}

\section{Conclusions}

o The current oversupply and relatively low prices of hydrocarbon fuels, especially petroleum, are short-term fluctuations within a long-term supply shortage. Given the large U.S. geothermal energy resource base and the potential for converting even a small percentage of this base into economically useful energy, developing 0.S. geothermal resources may be an important contribution to U.S. energy selfsufficiency.

- In the short term, private industry will continue to invest in technologies for exploiting hydrothermal resources. It will not invest in development for the longer-term resources of geopressured, hot dry rock, and magma energy. Because maintaining various energy supply options is critical, a viable and stable research program for these longer-term geothermal energy resources is necessary.

- In the near term, hydrothermal geothermal resources w1ll be used more than other geothermal resource types. Improving technologles for use should make many of the presently uneconomic resources competitive. Power production from geopressured and hot dry rock resources is potentially favorable for some sites, although using these resources is a longer-term 


\section{$7 / 8$}

possibility. Magma energy technologies are too uncertain now to make any reasonable economic projections.

- Significant strides in environmental controls for hydrothermal energy systems have been made since their early development. There has not been enough operating experience on other types of geothermal systems. Environmental problems remain, but they are site-specific and are thought to be remediable through appropriate study, engineering design, and construction practices.

- The geographical distribution of geothermal energy resource flelds is a constraint to geothermal energy use, one that could be alleviated by advances in superconducting materials and their use in electrical transmission lines.

- Institutional barriers are not a major constraint to geothermal energy development.

- Stable and adequately funded DOE R\&D is needed to determine and Improve the scientific, engineering, and economic feasibility of using energy from all types of geothermal resources. The short-term emphasis should be on hydrothermal systems and methods to facilitate their more rapid development.

- Long-term R\&D should be directed toward determination of the viability of geopressured, hot dry rock, and magma energy resources for future energy production. Expenditures in these areas can decrease as commercial viability is proved or disproved and industry begins to participate as projects are terminated.

- The existing GDO is one successful model of cooperation, which is judged to be the best cooperative approach to short-term R\&D related to drilling, given current energy economics and the state of the U.S. geothermal energy industry.

- The GDO model can and should be modified to address the wide range of short-through mid-term cooperative geothermal development activities.

Recommendations

- The DOE Geothermal Program should be funded at a somewhat higher and stable level (see Chapter 2, especially Table 2-5) to maintain viable R\&D programs for both near- and long-term geothermal resources. The funding recommended for each geothermal resource category is at a critical minimum level: it would decline over the period as anticlpated research goals are met (see Tables 2-2 to 2-4).

- The charter of the GDO should be expanded from its current coverage of "geothermal drilling" to "short- to mid-term geothermal development." The GDO's name should be changed to the Geothermal Development Organization and a restructuring implemented.

- A Geothermal Research Organization should be formed, composed of researchers interested in the scientific and technological issues in developing long-term geothermal energy resources: geopressured, hot dry rock, and magma energy. This organization would serve as an excellent means of coordinating the relatively small number of academic researchers working on these long-term resources and the large number of scientists working in allied fields. 



\author{
ISSUES, R\&D NEEDS, AND THE \\ DOE PROGRAM
}

\title{
GENERAL CONSIDERATIONS
}

Geothermal energy derives from the natural heat of the earth. Where natural conditions concentrate this heat, energy can be extracted and converted to either thermal or electrical energy to meet demand.

Potentially exploitable geothermal resources exhibit a considerable range of thermodynamic, hydrological, and geological conditions; they are classified as: hydrothermal, geopressured geothermal, hot dry rock (HDR), or magma energy resources. Hydrothermal geothermal resources are usually divided into two subtypes: (1) vapor-dominated fields, where dry steam exists in fractures, solution channels, and cavities in the reservoir rock and (2) liquid-dominated fields, where a fractured porous reservoir is saturated with hot water.

The Resource Base and U.S. Energy Supply

The U.S. geothermal energy resource base is large and widespread, offering a potentially important contribution to the U.S. energy supply. Current estimates place the total accessible energy in place from all four types of geothermal energy at greater than $1.2 \times 10^{6}$ quadrilion Btu (quads) (Muffler or USGS, 1979). The most favorable hydrothermal systems for power generation (the only type commercially developed) 1ie in the western states, including Alaska, as do most HDR and accessible magma deposits. However, other forms of geothermal energy are also found in most areas of the country. Low-temperature systems are avallable for direct heat applications in at least 30 states, and large geopressured geothermal resources are located along the Gulf of Mexico and the Pacific west coast and in Appalachia and various deep sedimentary basins (Muffler, 1979).

The energy recoverable from this geothermal resource base is uncertain, but it is estimated at approximately 4.5 percent of the 1.2 million quads, or 55,700 quads (Muffler or USGS, 1979). Such energy, the equivalent of 90,000 oil fields the size of Prudhoe Bay, is large in light of the U.S. annual energy consumption of 80 quads per year. Thus, geothermal energy might provide 600 to 700 years of the total U.S. energy requirement. 
Presently, only a fraction of this recoverable resource base can be produced at prices that are competitive with other energy sources. However, the fields under development in California, Nevada, Oregon, and Utah have the capacity for producing more than 10,000 MWe (megawatts electric) for 30 years according to U.S. Geological Survey (USGS) estimates.

Geothermal energy can become even more important as the costs of other energy sources rise, because the current. worldwide oversupply in hydrocarbon fuels is only a short-term phenomenon occurring within a long-term supply shortage. U.S. petroleum production is projected to decline from 11 million barrels per day (mbd) in 1985 to about 8 or 9 mbd in 1995, a decrease of 18 to 27 percent (DOE, 1987). The result will be a sharp rise in petroleum imports, primarily from the Middle East, unless domestic production increases. In addition, petroleum and natural gas industry capital expenditures for exploration and development have dropped 50 percent since 1981 (Hirsch, 1987).

Though a number of advantages can accrue from developing U.S. geothermal resources, the potential contribution of these resources to domestic energy production is certainly one of the most important.

Geothermal energy is Inherently a secure domestic source of energy that can reduce U.S. vulnerability to international forces. In addition, use of the small-scale modular geothermal power plants now available permits a fast reaction to either petroleum shortages or changes in electricity demand.

Geothermal energy, available continuously, is a baseload alternative to conventional fossil fuel and nuclear power plants. Given favorable economic circumstances, geothermal resources can be a reliable substitute for competing fuels. For existing geothermal power plants, availability factors are commonly higher than 95 percent, in contrast to U.S. averages of 78.7 percent for fossil fuel plants and 65.2 percent for nuclear plants (based on statistics from 1974 to 1983 of the North American Reliability Council).

Development of geothermal resources, then, presents important advantages for the United States. Development can proceed in two ways. Industry and government can let short-term market forces dictate a reduced development effort, or the present period of grace with low oil prices can be used to prepare for the next anticipated energy shortage.

Economic Issues and Projected Costs

Estimating the economics of energy extraction for the four geothermal energy resource types varies greatly, given their different stages of 
development. Even so, the general cost relationships delineated for hydrothermal energy use in Figure 2-1 are applicable to other geothermal resources.

In today's market, to compete with conventional sources of electric power generation, the cost of power must be within the range of 50 to 70 $\mathrm{mills} / \mathrm{kWh}$ ( 5 to 7 cents $/ \mathrm{kWh}$ ), the current range for electrical power produced from fossil fuels. Electric power from the vapor-dominated hydrothermal system at The Geysers, the only known vapor-dominated system In the Onited States, is competitive today. The least expensive liquid-dominated hydrothermal systems are expected to produce electricity at about $60 \mathrm{mills} / \mathrm{kWh}$, and a substantial fraction of hydrothermal resources is near the economic threshold.

The other types of geothermal resources are not commercial. Cost estimates and projections for each of the four types of resources are discussed in separate sections of this chapter.

The Utilities' Perspective

The commercial viability of geothermal generation for utilities is largely determined by the cost of generating and delivering the electric energy to the customer and by the power generation alternatives that may be available. Underlying both factors, of course, is the question of how much generating capacity, including new capacity, is needed.

Need Utilities will not actively pursue new geothermal hydrothermal power plants if their projections of load and capacity growth do not demonstrate the need for new capacity. In addition, utilities are presently striving to avoid projects that require new capital. Most western utilities are projecting a need for new capacity in the mid-1990s. All these factors have slowed U.S. geothermal development in the Immediate future.

Cost of Energy To ensure the greatest market penetration, the cost of the geothermal energy must be as low as possible, consistent with achleving the required reliability of supply. Aside from inflation, the major factors affecting energy cost at the busbar (the power plant switchyard) are reliablilty of the plant and reservoir operating as a unit and the cost of the energy.

Another factor affecting the cost of energy delivered to the customer is transmission. Many geothermal resources are located in falrly remote areas, removed from the centers of electricity consumption. Bulk transmission lines are usually not near to these resources. If they are, uncommitted transmission capacity in these lines may not be available. Advances in high-temperature superconducting materials and their application to electrical transmission lines may alleviate some of the constraints. 


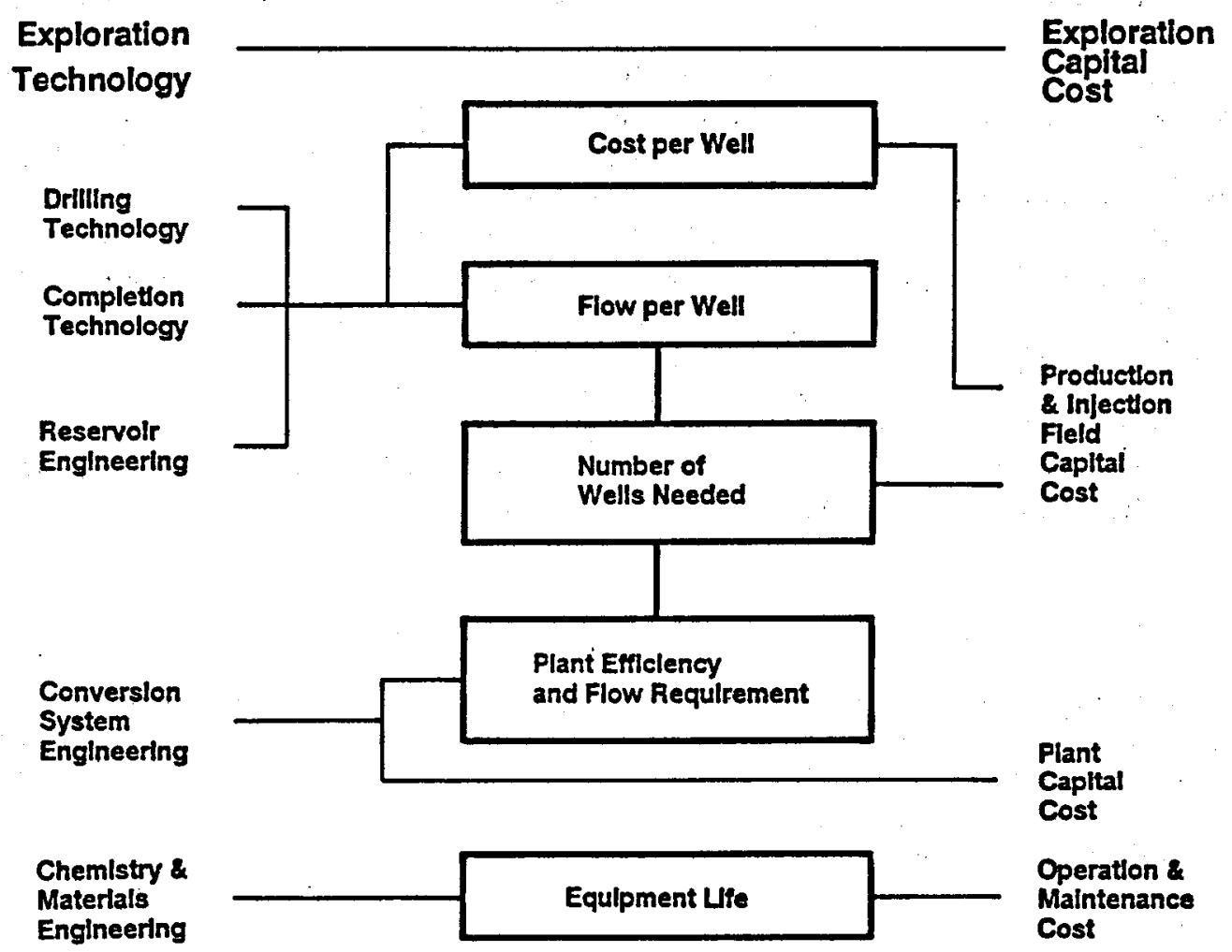

FIGURE 2-1 Geothermal Technology Cost Relationships. 
Generation Alternatives To find a place in a utility's resource plan, geothermal operation must be more attractive than other generation alternatives. Because geothermal generation is considered baseload generation, the alternatives are usually nuclear power and coal. In view of the uncertainties now associated with nuclear projects, coal is the alternative most often considered.

Another recent approach to defining the competition is through the concept of "avoided" costs. If, by being less expensive, a geothermal plant can displace (or avold) the energy and new capacity costs associated with other options in a utility's resource plan, it satisfies the avoided cost criteria.

Modularity and Size of Units Decisions and commitments to build geothermal projects are not as momentous as they are for large nuclear and fossil-fueled plants. Optimal development of most geothermal reservoirs requires the successive installation of small to medium-size power plants with a typlcal capacity of less than 100 wWe. Knowledge gained from the first small installations provides a basis for design in the commercial development of facilities.

\section{Conversion Technologies}

\section{Power Generation}

Three technologies are used for the conversion of geothermal heat into electricity (see Appendix C). In vapor-dominated geothermal flelds, the wells produce slightly superheated steam that is routed to a condensing steam turbine, which in turn drives a generator. In liquid-dominated geothermal fields, a single or double flash system is necessary. The production wells flow spontaneously as the liquid boils, resulting in a two-phase mixture of brine and steam at the surface. The mixture is routed to a separator where the liquid and vapor phases are separated; the saturated steam fraction is then used to power a turbogenerator, and the separated brine is reinjected. Alternatively, a double flash system entalls the flashing of the separated brine a second time to produce additional steam. For the third type, the binary cycle system, heat exchangers allow the hot brine to exchange its thermal energy with a working fluid having a low bolling point. This working fluid is vaporized, operating a turbine that in turn drives a generator. Binary cycles can be more efficient than flashed steam cycles for temperatures below $150^{\circ}$ to $180^{\circ} \mathrm{C}$. Thus, binary cycles are important to commercial development of the large moderate-temperature $\left(<150^{\circ} \mathrm{C}\right)$ U.S. geothermal resource.

\section{Direct Heat Utilization}

Because of the relatively low temperatures of geothermal fluids (typically $100^{\circ}$ to $300^{\circ} \mathrm{C}$ ), nonelectric direct uses are frequently 
attractive for geothermal systems. These uses include industrial process heat applications, in which geothermal fluids might be used to generate steam or hot water to supply heat to a manufacturing operation. In the paper industry, for example, large amounts of steam are required for pulp digestion and paper drying at temperatures from $100^{\circ} \mathrm{C}$ to $150^{\circ} \mathrm{C}$. Space-heating applications for geothermal heat are also possible when temperatures of $70^{\circ}$ to $100^{\circ} \mathrm{C}$ are suitable. Examples in the United States are found at Klamath Falls, Oregon, and Bolse, Idaho, and they are common in Iceland and the USSR. Even lower geothermal fluid temperatures $\left(<50^{\circ} \mathrm{C}\right.$ ) can be upgraded by heat pump design, as they are in Auburn, New York, and in France.

One economic advantage to process heat applications results from the inherently large load factors of many industrial processes. Space-heating applications are less attractive because of their lower load factors. Substantial use of geothermal energy for space heating in the United States would require extensive and costly retrofitting.

In some cases, cogeneration may be particularly well-suited to geothermal resources. Such cogeneration would include combined electric power and process heat supply systems for large industrial users and the use of geothermal heat for feedwater heating in a fossil-fueled base station power plant.

A substantial fraction of the U.S. annual energy budget of about 80 quads is consumed to produce heat used at temperatures below $20^{\circ} \mathrm{C}$. Recent estimates indicate that over 25 percent or about 20 quads per year would be potential targets for geothermal energy supply. clearly, the extent to which this energy source is used will depend in large part on the costs of geothermal heat relative to the competition, particularly natural gas and oll. Important factors for direct heat use include the distance between the geothermal resource and end user, which is critical to fluid distribution costs; the chemistry of the geothermal fluid, because it may lead to corrosion and scaling of heat exchange surfaces; and the quality of the resource in terms of temperature and depth.

\section{Environmental Concerns}

Geothermal power projects are environmentally preferable to other sources of electricity for several reasons. First, geothermal projects produce the resource and convert it to electricity at the same location, limiting adverse effects to one area. In contrast, the effects of coal-fired power plants include not only those at the plant but also those from mining, transportation via slurry pipeline or rail cars, stockpiling, and storage. In addition, since enactment of the 1978 Federal Power Plant and Industrial Fuel Use Act, coal has been the fuel predominantly used for power plants, and its combustion allegedly contributes to two pressing environmental problems: acid rain from sulfur dioxide emissions and "the greenhouse effect" from carbon dioxide emissions. Further, perceived nuclear risks have made construction of nuclear power plants increasingly unpopular. 
Some environmental effects are common to different resources and localities, though their importance and severity vary from site to site. These potential effects include those on land use; air emissions; production of waste products from environmental control, some of which may be hazardous; water consumption and water quality; land subsidence; induced selsmicity; and noise.

Building a geothermal or any other power plant causes land use and visual changes, but careful development has minimized them. As discussed later, hydrogen sulfide $\left(\mathrm{H}_{2} \mathrm{~S}\right)$ abatement procedures have successfully reduced air emissions to acceptable levels. However, these procedures result in solid wastes that must be disposed of. Prior to disposal, industry is considering the recovery of $z$ inc, lead, silver, and other useful products.

Operating geothermal plants produces wastes because of the pollutants in geothermal fluids. A new federal Environmental Protection Agency study of geothermal drilling wastes could lead to a requirement for their off-site disposal if the study concludes that they meet any of the definitions of hazardous characteristics set forth in regulations pursuant to the Resource Conservation and Recovery Act (40 CFR Part 261). Such a requirement would have 11ttle effect on Imperial County, California, for example, where in order to protect agricultural interests, on-site disposal is not allowed.

With regard to geothermal plants' consumption of water, dry steam and flashed steam systems use their own condensed steam for cooling and inject excess fluids into the geothermal reservoir.- This arrangement is a water-Independent technology for dry steam plants, neither drawing from nor discharging into any publicly accessible waters. However, the use of flash steam plants may require make-up water under some operating conditions for part of the year. The use of binary systems for power production from moderste-temperature hydrothermal, hot dry rock, and geopressured systems requires an external source of cooling water. When cooling water is required for power plant operation, water could become a critical issue in areas with water shortages.

Land subsidence is also site-specific, depending on the characteristics of the geothermal reservolr and the amount of fluid produced. The problem can be alleviated or avolded altogether in one or more ways. One way is to stop withdrawal. Another is to repressure the reservolr by reinjecting of geothermal fluids or surface waters. In any event, the problem must first be identified and Its possible deleterious effects evaluated. Industry is working closely with local government and agricultural interests to maximize the return of produced fluids into reservolrs and to monitor ground levels carefully so that prompt corrective action can be taken if necessary. So far, this has not been needed.

Injection of fluids into the ground can increase microselsmic activity (earthquakes too small to be detected other than by sensitive instruments). These effects are highly site-specific. However, analysis of the energy involved in earthquakes suggests that infection is highly unlikely to trigger potentlally damaging events. There are local requirements in certain earthquake-prone areas, such as the 
Imperial Valley in California, that require monitoring microseismic activity to develop baseline studies and to distinguish between induced and natural seismic activity.

Noise pollution can be a problem, particularly during drilling and testing. Once a geothermal fleld is producing, however, noise levels are easily reduced to acceptable levels. During production, the geothermal fluids normally flow fairly silently through insulated pipes to the power plant. However, flulds may escape nolsily from newly drilled wells or wells undergoing tests, pressurized hot water in liquid-dominated flelds being discharged to the atmosphere and flashing in the process, and possibly large quantities of steam vented to the atmosphere when a power plant is shut down either inadvertently or for maintenance. All these noises are presently mitigated by means of mufflers that destroy the kinetic energy of the discharging fluids, reduce the volume of noise and deflect it skyward, and lower the pitch to a frequency level tolerable to people.

\section{Generic Development Needs}

Hydrothermal reservoirs with favorable characteristics are being exploited competitively, and the major short-term emphasis is on techniques that enable development of lower-quality reservoirs. As these technologies are developed, they can be extended to the other geothermal resources. Further development of techniques is needed to locate, delineate, characterize, and manage geothermal reservoirs. Drilling costs are high because of high temperatures, hard rocks, and corrosive fluids. The ability to reduce these costs will greatly enhance the economic competitiveness of geothermal energy development. Corrosive geothermal waters cause early fallure of materials if corrosion prevention techniques and resistant materials are not used. Research and development (R\&D) is needed on corrosion prevention techniques, high-temperature elastomer formulations for dynamic seals, cost-effective corrosion-resistant materials, elastomer-1ined casings, and materials for heat exchanger tubing and well casings. Downhole pumping, which is often used for moderate-temperature resources, requires reliable motors and cables. Measuring, recording, and evaluating downhole conditions requires the development of reliable high-temperature downhole instrumentation. Successful exploitation of a reservolr requires technology for disposing of large quantities of spent brines. Often, the fluid must be disposed of by subsurface injection. To ensure efficient injection, R\&D is required on siting infection wells and improving application of tracer methods for predicting and monitoring fluid migration. Developments required for conversion technologies include Improved performance cycles and components (see Appendix D and later sections in this chapter). 


\section{CURRENT STATUS OF THE DOE PROGRAM}

Industry has conducted geothermal R\&D since the 1950s. The federal government has been involved since a geothermal program was established by the Atomic Energy Commission (AEC) in 1971 (see Appendix E for a description of private and public R\&D). In 1977, federal efforts were moved to the Department of Energy (DOE), with a formal commercialization program accounting for the largest part of the budget from 1977 to 1981 (see Table 2-1). This formal commerclalization program was initiated in 1977 to promote early use of hydrothermal resources for both power generation and direct use. A policy decision in 1981 shifted emphasis from commercialization back to $R \& D$, where it remains today.

As can be seen from Table 2-1, DOE's budget for geothermal energy development declined significantly from $\$ 158$ million in 1979 to about $\$ 21$ million in 1987. The current low prices of petroleum have decreased the urgency of pursuing R\&D in alternative energy technologies. DOE's budget has been cut for R\&D in alternative technologies, affecting development of the four geothermal resource types and their potential contribution to U.S. energy supply.

At the direction of Congress, DOE's long-term responsibility for geothermal energy $R \& D$ is to determine and improve the scientific, engineering, and economic feaslbility of using energy from all types of geothermal systems. This R\&D is to provide options to be developed by the private sector in response to market forces.

The development of technology for hydrothermal energy, the most attractive for technical and economic reasons, recelves near-term emphasis by both government and industry. Hydrothermal reservolrs with the most favorable characteristics are being exploited competitively. Thus, the major short-term focus is on improving the feasibility and economics of hydrothermal development of reservoirs of lower quality. In the long term, these technologles can be used to locate more hydrothermal resources and develop geopressured, hot dry rock (HDR), and magma energy resources.

$R \& D$ funds for HDR and magma energy extraction are included under the umbrella of geothermal technology development, but they are listed separately in Table 2-1. The HDR program was launched in 1973 with one-third the total AEC geothermal energy budget, and in 1974 this program element recelved more than half the $\$ 7$ million appropriated for geothermal R\&D. The geopressured geothermal energy program began in 1974. Magma energy extraction R\&D was not undertaken unt11 1984, after seven years of scientific study funded by DOE's Office of Basic Energy Sciences, which was designed to test its technical feasibility.

\section{HYDROTHERMAL RESOURCES}

\section{Resource Description}

Hydrothermal energy includes water and steam trapped in fractured or porous rocks. Hydrothermal systems are liquid-dominated or 
TABLE 2-1 Budget History of the DOE Geothermal Technology Program (in millions of dollars)

\begin{tabular}{|c|c|c|c|c|c|c|c|}
\hline Year & $\begin{array}{l}\text { Hydrothermal } \\
\text { Industrialization }\end{array}$ & $\begin{array}{l}\text { Geothermal } \\
\text { Technical } \\
\text { Development }\end{array}$ & $\begin{array}{l}\text { Geopressured } \\
\text { Resource } \\
\text { Development }\end{array}$ & $\begin{array}{l}\text { Hot Dry Rock } \\
\text { Resource } \\
\text { Development }\end{array}$ & $\begin{array}{l}\text { Magma } \\
\text { Resource } \\
\text { Development } \\
\end{array}$ & Other & Total \\
\hline $\begin{array}{ll}\text { FY } & 1976 \\
\text { TQ } & \\
\text { FY } & 1977 \\
\text { FY } & 1978 \\
\text { FY } & 1979 \\
\text { FY } & 1980 \\
\text { FY } & 1981 \\
\text { FY } & 1982 \\
\text { FY } & 1983 \\
\text { FY } & 1984 \\
\text { FY } & 1985 \\
\text { FY } & 1986 \\
\text { FY } & 1987\end{array}$ & $\begin{array}{r}13.3 \\
5.0 \\
23.7 \\
54.5 \\
70.9 \\
70.4 \\
55.4 \\
31.2 \\
33.0 \\
2.0 \\
1.0 \\
1.9 \\
2.0\end{array}$ & $\begin{array}{r}10.5 \\
3.1 \\
11.8 \\
29.2 \\
42.6 \\
26.0 \\
33.9 \\
10.4 \\
6.9 \\
14.3 \\
13.3 \\
10.1 \\
5.6\end{array}$ & $\begin{array}{r}0.3 \\
0.8 \\
6.6 \\
16.5 \\
27.7 \\
36.0 \\
31.9 \\
16.7 \\
8.4 \\
5.0 \\
5.4 \\
4.4 \\
4.0\end{array}$ & $\begin{array}{c}4.0 \\
1.6 \\
6.0 \\
6.0 \\
15.0 \frac{\mathrm{b}}{15} \\
15.0 \mathrm{~b} \\
14.0 \mathrm{~b} \\
10.0 \frac{\mathrm{b}}{} \\
7.5 \frac{\mathrm{b}}{\mathrm{b}} \\
7.3 \mathrm{~b} \\
9.4 \underline{\mathrm{b}} \\
7.1 \mathrm{c} \\
8.0\end{array}$ & $\begin{array}{l}- \\
- \\
- \\
- \\
- \\
- \\
- \\
- \\
- \\
0.8 \\
1.3 \\
1.7 \\
0.5\end{array}$ & $\begin{array}{l}3.2 \\
1.3 \\
4.9 \\
1.7 \\
1.8 \\
1.8 \\
2.3 \\
1.6 \\
1.3 \\
1.1 \\
1.7 \\
1.2 \\
0.8\end{array}$ & $\begin{array}{r}31.3 \\
11.8 \\
53.0 \\
107.9 \\
158.0 \\
149.2 \\
137.5 \\
69.9 \\
57.1 \\
30.5 \\
32.1 \\
26.4 \\
20.9\end{array}$ \\
\hline Total & 364.3 & 217.7 & 163.7 & 110.9 & 4.3 & 24.7 & 885.6 \\
\hline
\end{tabular}

a Three-month period when the federal government changed the fiscal year beginning from July 1 to October 1. $\underline{b}_{\text {An }}$ additional $\$ 5$ million was provided by the Federal Republic of Germany ( 50 percent) and Japan ( 50 percent). $\mathcal{c}_{\text {An }}$ additional $\$ 2.5$ million was provided by Japan.

SOURCE: DOE (1987). 
vapor-dominated (steam), based on the dominant phase in the fractures and large pores. Wells used to recover this type of energy are usually a few hundred to as much as $4,000 \mathrm{~m}(14,000 \mathrm{ft})$ deep. The temperatures for power production range from $150^{\circ}$ to $360^{\circ} \mathrm{C}\left(300^{\circ}\right.$ to $\left.680^{\circ} \mathrm{F}\right)$, with most useful temperatures at the upper end of the range. The highest-quality U.S. hydrothermal resources are in the western states, where relatively young volcanoes or a thinning of the earth's crust are assoclated with many shallow high-temperature systems. A large number of low-temperature systems $\left(<90^{\circ} \mathrm{C}\left[194^{\circ} \mathrm{F}\right]\right)$ are also found in the west, with more scattered occurrences in the eastern and central states (Reed, 1983).

Power generation with the dry steam from vapor-dominated reservoirs has been commerclal for a number of years. Very hot water systems ( $>180^{\circ} \mathrm{C}\left[350^{\circ} \mathrm{F}\right]$ ) have recently been developed for power production in the United States. In addition, moderate-temperature systems are being successfully used for operating small binary cycle conversion units and in many nonelectric applications where the heat of the fluids is used directly. Technology for using hot water in the moderate temperature range, from $90^{\circ}$ to $150^{\circ} \mathrm{C}\left(194^{\circ}\right.$ to $\left.300^{\circ} \mathrm{F}\right)$, for power plants is still in the development phase.

Resource Base

In the foreseable future, the resource base of hydrothermal systems is limited to that part of the resource shallow enough to be reached by production drilling to a depth of about $3 \mathrm{~km}(10,000 \mathrm{ft})$. Assessments of the U.S. resource base by category are as follows (Muffler, 1979; White and Williams, 1975):

- High-temperature $\left(>150^{\circ} \mathrm{C}\right)$ vapor-dominated systems: 300 quads (49 billion bbl petroleum equivalent)

- High-temperature $\left(>150^{\circ} \mathrm{C}\right)$ hot-water systems: 4,500 quads $(742$ billion bbls petroleum equivalent)

- Intermediate-temperature $\left(90^{\circ}\right.$ to $\left.150^{\circ} \mathrm{C}\right)$ water systems: 4,900 quads ( 809 billion bbl petroleum equivalent)

- Low-temperature $\left(<90^{\circ} \mathrm{C}\right)$ water systems: 34,000 quads $(5,600$ billion bbl petroleum equivalent).

Together these resources represent nearly 44,000 quads of energy, the equivalent of 7,200 billion bbl of petroleum or approximately 720 Prudhoe Bay petroleum flelds. These estimates of the resource base are speculative, but in comparison to the annual U.S. petroleum production of about 4 billion bbl, recovery as low as 1 percent would still represent a gigantic energy resource.

Current Status of Development

Worldwide power generation with geothermal energy from hydrothermal resources is in its eighty-fourth year. The first experiment was 
conducted at Lardere110, Italy, in 1904, when five 1ight bulbs were lighted with the electricity produced from a small dynamo driven by geothermal steam. From this early beginning, the geothermal power generation capacity at the Larderello steam field, one of the few dry steam fields identified worldwide, has grown to about 500 MWe. A total of 900 MWe is projected for 1995.

The largest geothermal field in the world is The Geysers, a vapor-dominated (steam) field in Sonoma County, California, 75 miles north of San Francisco. Developments began in 1960 with a 12 MWe powergenerating facility that has grown to 1,800 MWe. Total development capacity is estimated at more than 2,000 WWe. This electricity produced from The Geysers field will displace 800 million bbl of petroleum needed to generate the same amount of electrical energy over the life of all the power plants at this generating facility.

Liquid-dominated hydrothermal power generation outside the United States began in New Zealand in 1959 with an 11-MWe unit. Today, units totaling a 167-MWe capacity are operating at two sites, and additions. totaling nearly 120 MWe are planned.

Mexico, the Philippines, and Indonesia all began aggressive geothermal programs in the 1970 s, and geothermal power currently accounts for a substantial percentage of the total power generated in these countries. Geothermal power production not only provides developing countries an indigenous resource but also permits those with exportable energy resources to sell them abroad and generate foreign currency (Kestin, 1980).

In the United States, the use of 1iquid-dominated hydrothermal geothermal resources was initiated in the Imperial Valley, California, in 1979 with the operation of a 12.5-MWe binary power plant.

Subsequently, a 10 -MWe flash power plant in 1980 and the world's largest binary power plant of 45 uWe in 1985 were put into operation. From mid-1979 to mid-1986, worldwide geothermal capacity grew 269 percent, for an annual growth rate of 15 percent (DiPippo, 1986).

In addition to generating electric power, hydrothermal geothermal energy is used in many nonelectric applications worldwide. For example, geothermal steam provides process heat for pulp and paper production in New Zealand. In Iceland and in Oregon and Idaho, water-dominated resources are used for space heating (see Appendix F for an inventory of geothermal plants).

\section{Economic Issues and Projected Costs}

The cost comparisons in hydrothermal power development are illustrated in Figure 2-1. In this context, the most important objectives are reducing fluid production costs and fluid flow requirements per unit of energy output. The same objectives hold for other geothermal resources. In the current energy market, the cost of generating new capacity at The Geysers make thermal power one of the lowest-cost generation options. It is competitive with new gas turbines and would be cheaper than a conventional petroleum-, coal-, or nuclear-fueled 
plant. Hot water geothermal development is more complex than at The Geysers and therefore is more costly, but as shown in Figure 2-2, electricity from this source should be cheaper than from a newly installed coal- or nuclear-fueled plant.

If fossil fuel prices return to 1985 levels, the cost advantages of gas turbines and gas- or oil-fired steam electric plants diminish and electricity from geothermal resources, whether steam or hot water, becomes more attractive than the other options. This point is Illustrated in Figure 2-3.

\section{Environmental Concerns}

Among other considerations, land use is a part of hydrothermal resources development. Most projects in operation are in rural or undeveloped areas. In the Imperial Valley of California, the projects were designed to minimize the amount of land removed from agriculture. Drilling pads are located at corners of fields and pipelines routed along farm roads. For the quiet resort areas near The Geysers steam fleld, strong consideration was given to the visual effects of each plant and pipeline, particularly those that could be placed atop the mountain ridges. Though only 5 to 10 percent of the total project area was used for well pads, power plants, roads, and pipelines, this undeveloped area definitely changed character.

Other environmental factors require special consideration in developing hydrothermal resources, typifying some of the "worst case" situations in geothermal development. Major environmental concerns that earlier impeded geothermal development include the odor of hydrogen sulfide at The Geysers and the high salinity of the fluids in the Salton Sea and Brawley reservolrs in Imperial Valley. In addition, solutions to these "worst cases" produce anclllary waste streams that now represent the most costly environmental requirement confronting the industry--1and disposal of wastes deemed hazardous under federal and state regulations.

Methods used to control the $\mathrm{H}_{2} \mathrm{~S}$ emisslons at The Geysers are now in full compliance with stringent California requirements. However, nearly all these methods produce sludges containing trace levels of arsenic, mercury, vanadium, and other metals. If concentrations of these elements exceed the maximum values set forth in Title 22 of the California Administration Code, they must be disposed of at a stateapproved hazardous waste disposal site.

In the Imperial County of southern California, geothermal power production with the hypersaline fluids at the Salton Sea and Brawley reservoirs is possible only with a technology that creates a sludge containing primarily silica. This process removes the solids from the brine ahead of the turbine and again before infection. A 34-MWe dual flash plant in the area produces about 50 tons of sludge for disposal every 24 hours. Because of the large volume of these wastes, the county planning officlals, while welcoming the benefits of geothermal development, are concerned about the continued avallability of disposal facilities. 


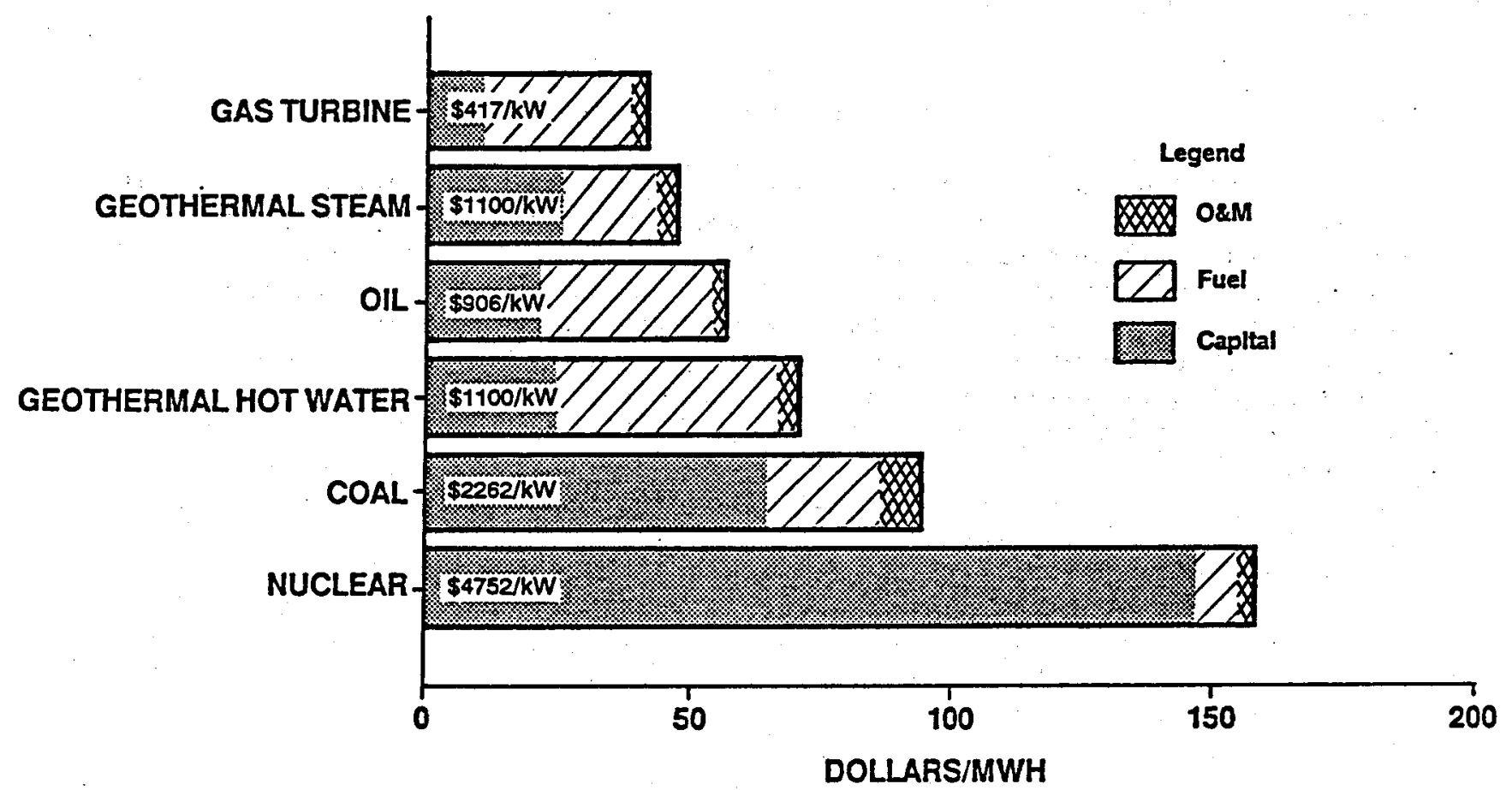

FIGURE 2-2 Estimates of Electricity Costs with 011 at $\$ 18.50$ per Barrel.

SOURCE: Based on data from the California Energy Commission (1985). 


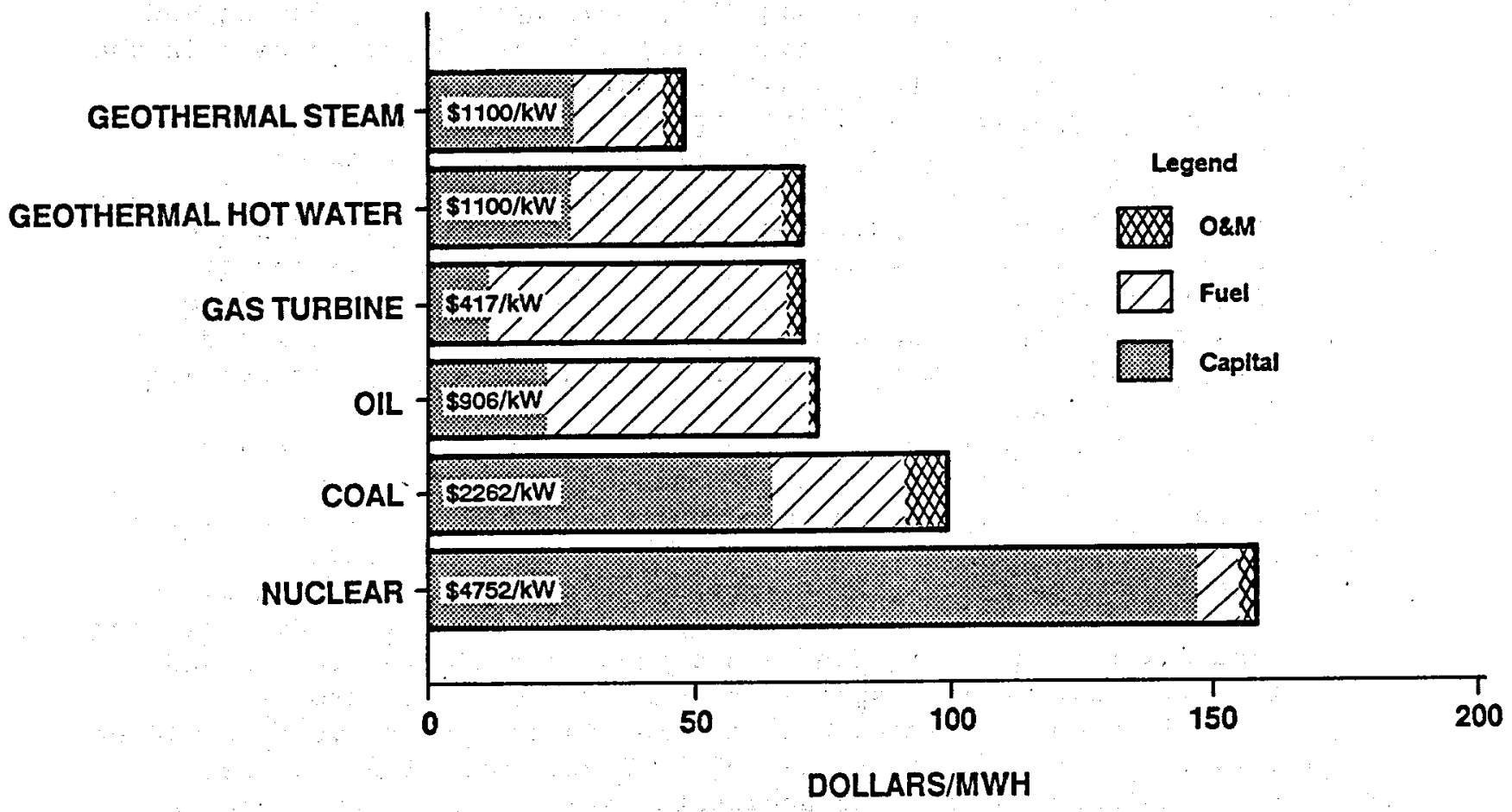

FIGURE 2-3 Estimates of Electricity Costs with 011 at $\$ 28$ per Barrel.

SOURCE: Based on data from the California Energy Commission (1985). 
The chemical nature of the resource and its environmental effects 1imit its development. The Forest Service and, to a less extent, the Bureau of Land Management, have determined that geothermal operations are not compatible with other authorized land uses in areas considered environmentally sensitive. For example, the Forest Service denied geothermal leasing in the Mt. Lassen, California, Known Geothermal Resource Area (KGRA), as it has done in promising areas in Oregon and other less prominent areas. Congress also foreclosed any leasing in the Island Park KGRA adjacent to Yellowstone National Park.

More recently (October 18, 1986), Congress placed additional restraints on federal land use, with a rider to the Continuing Appropriations Resolution for Fiscal Year 1987 (P.L. 99.5000). Leases issued must now include stipulations to protect the thermal features, including the right of the government to suspend the activities of leaseholders, temporarily or permanently, if they are determined to exert an adverse effect. In consenting to a lease on forest lands, the Secretary of Agriculture must also consider the effects of activities authorized by the lease.

Another environmental consideration is land subsidence. At The Geysers, condensed steam is injected to maintain reservoir pressures and minimize subsidence. Injection should not affect the quality of local water resources if care is taken in design, construction, and maintenance. Groundwater aquifers are protected by specially designed well casings cemented in place in each well. Roads, well pads, drilling sumps, and power plant sites can be designed to minimize erosion and to control spill drainage into special catchment basins for proper disposal. All produced flulds not consumed in the power cycle should be reinjected into the producing reservoir. These operations can be monitored regularly to minimize accidental spills that might reach a watercourse.

\section{Feasibility and Impediments to Growth}

The issues of feasibility and impediments to growth, discussed briefly under "Generic Development Needs," are detalled in Appendix D. Again, these technologies must be developed for all types of geothermal resources. Specific R\&D recommendations are made in the section below. Institutional factors, such as permitting requirements, leasing laws, regulations, and tax treatment can always be improved upon. Currently, they present no insurmountable barriers for geothermal development except in a few specific cases. Federal and state governments need to streamline the approval process in order to minimize incurred costs.

Research and Development Program

To determine the research needs and priorities of the geothermal industry, DOE obtains information from many sources; the latest was consolidated in DOE's 1986 research plan. It was reviewed at a meeting 
at the Los Alamos National Laboratory on October 15 and 16, 1986, by 20 people from the U.S. geothermal community (see Appendix G). The Hydrothermal Technology Program described here is the program presented by this review panel to the DOE Assistant Secretary for Conservation and Renewable Energy. The longer-term resources of geopressured, hot dry rock, and magma energy are discussed elsewhere. The Los Alamos review panel concluded that technology is the major barrier to growth of the geothermal industry and that improvement and developments are necessary in the areas listed below.

\section{Reservoir Technology}

The objective of research in reservolr technology is improvement in delineating, characterizing, and managing hydrothermal reservoirs to predict their long-term behavior and to design optimal production and injection strategles. Utilities and financial institutions are reluctant to commit funds and other resources to a geothermal project if long-term production is not ensured. Work in this area can be classified as follows:

- Reservoir definition--Improvement of surface and borehole geophysical, geological, and geochemical methods for:

1. Reservolr location and delineation

2. Hydrological modeling

3. Fracture detection

- Reservolr performance--Improvement of predictions of reservoir performance over 30 -year lifetimes requiring development in:

1. Well testing

2. Performance matching

3. Reservoir modeling

4. Reserve forecasting

5. Geophysical and geochemical monitoring

- Field management--Improvement of energy extraction and reservoir operations. Additional work is required on:

1. Well spacing

2. Injection

3. Computer modeling

4. Well completion and operation

5. Scaling and corrosion

- Field cast studies-Testing and transfer of technology through cooperative studies of currently operated flelds in the United States and abroad on all types of hydrothermal systems:

1. Low- and moderate-temperature systems

2. High-temperature systems

- hot water (fracture and matrix-controlled systems)

- vapor-dominated systems 


\section{Drilling Technology}

Reducing drilling costs can most improve the economics of geothermal projects. The objective of proposed research is to reduce costs 5 percent per year for 10 years, thus cutting drilling development costs one half. Development to improve drilling technology is required in the following areas:

- Hard rock penetration:

1. Drilling bits, reamers, etc.

2. Coring bits

3. Downhole motors and turbines

- Formation testing and well completions:

1. Open-hole packers

2. Reservoir stimulation

3. High-temperature cements and cementing techniques

- Drilling flulds and lost circulation control including lower cost, high-temperature fluids.

\section{High-Temperature Instrumentation}

A subcategory of drilling technology is the information gathering devices used in wells during drilling or after completion. In this area, improvement is needed in an array of instruments:

- Fracture detection and mapping

1. Acoustic televiewer

2. Downhole radar and electromagnetic tools

3. Downhole seismic instruments (for vertical seismic profiling, geophones)

- Electric cables

1. Armored multiconductor

2. Fiber optics

- Fluid samplers

- Logging tools

1. Geophysical monitors

2. Pressure monitors

\section{Conclusions and R\&D Budget Recommendations}

Based on the above discussion of hydrothermal energy resources, the committee reached the following conclusions about hydrothermal resources :

- Estimates of the hydrothermal resource base are speculative but so large that a small recovery factor represents a large addition to U.S. energy supply. 
- Some hydrothermal resources are now economically competitive. Technology development and higher fossil fuel prices will make other hydrothermal resources economic.

- For hypersaline solutions, the most costly environmental problem confronting the industry is land disposal of solid wastes, some of which are deemed hazardous.

- Institutional factors are not insurmountable barriers to geothermal development, except in a few special cases, but they need to be streamlined to reduce costs.

Based on the R\&D needs listed above, the committee recommends funding for DOE hydrothermal development slightly less than $\$ 17$ million per year for three years (1988 to 1990) followed by $\$ 14$ million per year for 1991 and 1992 (see Table 2-2). For a successful program, significant and stable funding over a number of years should be committed. Such funding is required for an orderly and systematic research program and for attracting the most qualified people to R\&D activities. With this type of commitment, the committee estimates that cost-sharing funds may be obtained from industry at about $\$ 3.5$ million per year for drilling technology and high-temperature instrumentation. The committee also believes that with further research successes, the funding could be reduced somewhat later in the flve-year perlod.

\section{GEOPRESSURED GEOTHERMAL RESOURCES}

\section{Resource Description}

Geopressured geothermal energy is unique, consisting of three forms of energy: water at temperatures of $150^{\circ}$ to $230^{\circ} \mathrm{C}\left(230^{\circ}\right.$ to $\left.450^{\circ} \mathrm{F}\right)$ at typical depths of $15,000 \mathrm{ft}$ or more, natural gas (methane) dissolved in the water at solution gas levels averaging 25 to 40 standard cubic feet (scf)/bbl of water, and hydraulic energy in the form of pressure. The pressure gradients approach 1 psi/ft, almost twice the normal pressure gradient, and allow the water and contained natural gas to flow to the surface at extremely high pressures.

The principal U.S. location of these resources is beneath known oil and gas deposits in the Gulf coast of Texas and Louisiana, but geopressured geothermal resources have also been found in six other basins in the country, including the Central Valley of California. At least 60 similar basins are known in other countries, and probably many others are yet to be discovered in the United States and elsewhere by deep drilling beneath established petroleum-producing provinces.

\section{Resource Base}

Resource assessments for both methane and thermal energy from water have been published by the U.S. Geological Survey (USGS, 1979). Assessment was limited to the onshore portion of the U.S. Gulf coast and to a depth of $6.86 \mathrm{~km}(22,500 \mathrm{ft})$ from the surface. Resources contained in the 
TABLE 2-2 Committee Budget Recommendations for Hydrothermal Development in the DOE Geothermal Technology Program (In millions of dollars)

\begin{tabular}{lccccc}
\hline & \multicolumn{5}{c}{ Fiscal Year } \\
\cline { 2 - 5 } Element & 1988 & 1989 & 1990 & 1991 & 1992 \\
\hline Reservoir technology $\underline{\text { a }}$ & 7.0 & 7.0 & 7.0 & 6.0 & 6.0 \\
Drilling research & 4.0 & 4.0 & 4.0 & 3.0 & 3.0 \\
$\begin{array}{l}\text { High-temperature } \\
\text { instrumentation }\end{array}$ & 1.5 & 1.5 & 1.0 & 1.0 & 1.0 \\
$\begin{array}{c}\text { Conversion technology } \\
\begin{array}{c}\text { Cross-cutting research } \\
\text { Total }\end{array}\end{array}$ & 3.0 & 3.0 & 3.0 & 3.0 & 3.0 \\
\hline
\end{tabular}

Industry cost-shared funding estimated by the committee at $\$ 3.5 \mathrm{million}$ per year. 
sandstones are estimated at 5,800 quads of thermal energy and 3,220 quads of natural gas. No estimate was made of hydraulic energy recoverable from the high wellhead pressures.

Although current fleld tests indicate larger than expected recoveries from geopressured geothermal resources, the USGS conservatively estimates only a 3-percent recovery from the onshore portion of the Gulf coast basin, or 164 quads of thermal energy and 102 quads of natural gas. This estimate thus totals 266 quads of recoverable energy for one third of the basin, an addition of 137 percent to currently known natural gas reserves in the coterminous United States. Given the conservative nature of this estimate, it is apparent that the geopressured resource may represent a large addition to the U.S. energy base, depending, however, on Its economics compared to other energy sources.

\section{Current Status of Development}

The geopressured geothermal program is still in development. Research and fleld testing began in 1974, under the auspices of DOE and Its predecessor agencies, to provide the scientific and technological base for determining technical feasibility. Once the resource base was established and research in geology and engineering had developed methods for fleld testing, DOE inftiated the following steps: (1) selection of "wells of opportunity," that is; wells drilled by industry in search of petroleum or natural gas without success, to be taken over and flow tested for short perlods to examine flow rates, natural gas content, and pressures; (2) drilling of new wells at geologically optimal locales to assess long-term reservolr performance; and (3) studies of environmental effects while production of design wells was monitored.

The "wells of opportunity" program began in 1978. Nine wells were tested for one week each. These tests confirmed the researchers' belief that natural gas was present everywhere at saturation levels or higher. In fact, one well produced natural gas during testing and was returned to the operator for commercial production. The test also appeared to validate high flow rates and pressures but could furnish no information on long-term reservoir performance.

Four new wells drilled in Texas and Louls lana between 1979 and 1982 were Instrumented for long-term performance tests. Testing of two is complete; the other two are still undergoing flow tests. One, the No. 2 Pleasant Bayou well in Texas, will be the site of an electrical demonstration facility under the sponsorship of the Electric Power Research Institute (EPRI). This hybrid facility will include a gas-fired turbine, a binary cycle thermal power system, and a pressure reduction turbine to generate electricity from all three forms of energy present at the wellhead.

Industry pioneered the binary cycle thermal system in geothermal fields in the Imperial Valley of California, but the system combining all three energy sources has not been attempted before. 
The No. 1 Gladys McCall well in Louisiana has produced almost 23 million bbl of hot water to date, and more than 1 million cubic feet (MMCf) of natural gas per day is sold. This is the first well of its type to produce in excess of $30,000 \mathrm{bbl}$ of water per day and, at the same time, to have natural gas sold in quantities formerly associated only with commercial gas wells. Mobil oil Company has offered DOE another well in Louisiana for testing. This well appears to have optimally geopressured sandstones, with some possibly containing free gas in excess of solution gas levels of 25 to $40 \mathrm{scf} / \mathrm{bbl}$. However, current budgetary constraints will permit testing only one well in the fiscal year 1987 to 1988 .

\section{Economic Issues and Projected Costs}

Although geopressured geothermal resources are not economically attractive under current energy market conditions, they need further investigation. It is estimated that geopressured gas can be produced without electrical power usage for approximately $\$ 5$ per thousand cubic feet (McF), but the EPRI power demonstration facility will provide a better test of use and costs. Binary cycle systems capable of extracting heat from water at $167^{\circ} \mathrm{C}\left(300^{\circ} \mathrm{F}\right)$ are in commercial service in the western states. The additional boost from hydraulic energy and natural gas power generation possible only with this resource may further improve the economics and interest industry, once long-term evaluations of reservoir performance and equipment provide more information on the energy that can be produced.

\section{Environmental Concerns}

Environmental studies on geopressured geothermal energy use began in 1975 at both the University of Texas and Louislana State University. They indicated that the principal environmental effects to be monitored are reinjection and disposal of water and potential subsidence from withdrawing large volumes of water. As a result, injection wells were drilled alongside the new wells and plans made to reinject spent waters into shallow ( $1.22 \mathrm{~km}$ deep) saline aquifers beneath all freshwater zones in accordance with state commission regulations. To date, the reinjection program has proceeded with spectacular success. More than 22 million bbl of water have been reinjected at the Loulsiana well site at very low surface pressures ( $300 \mathrm{psi}$ ) without difficulty. This is probably the largest quantity of water ever infected in one well in the Gulf coast.

Subsidence is more difficult to address, because it may be a long-term effect. Newly drilled wells were instrumented at the time of completion with radioactive tracer bullets to check for compaction of sediments later. Sites at locales will be surveyed for changes in ground elevations. So far, there is no evidence of subsidence. However, monitoring is necessary at both sites as fluid withdrawal continues, particularly in south Louisiana, where natural subsidence (at about $2 \mathrm{~mm}$ per year) is lowering elevations and causing loss of land. 
Feasibility and Impediments to Growth

Aside from current economics, the principal requirements for increased industrial interest in geopressured geothermal resources relate to long-term performance, verification of reservolr models, other technology new and unique to this energy source, and confidence in a lack of environmental constraints. Research has achleved many breakthroughs, and early problems no longer of concern include improved logging interpretation, prevention of scaling in wells, and reinjection. of continuing concern is reservoir behavior. Recent well tests indicate that pressures higher than predicted are being sustained, but the causes are questionable. Under investigation are dewatering of adjacent shales and high bulk compressibility of sediments. The mechanisms controlling fluid flow in these reservolrs are clearly different from those of conventional hydrocarbon reservoirs, and models developed by industry require modification. Long-term testing is required to determine continued productivity and well spacing. Similarly, the environmental issue of subsidence will require monitoring in both wells and at the surface of each well site for several years to verify the satisfactory results to date.

\section{Conclusions and R\&D Budget Recommendations}

Based on the preceding discussion, the following conclusions were reached:

- Geopressured geothermal resources may represent a large addition to the future U.S. energy supply.

- The principal environmental issues for use of this resource are reinjection and disposal of water and potential subsidence from withdrawal of large volumes of water.

The current $\$ 4$ million DOE budget for development of geopressured geothermal resources is sufficlent to continue to test one design well, put in place the EPRI electric power demonstration experiment, and at the same time monitor subsidence at one site. As a result, DOE is considering shutting out the Loulsiana well, which has the longest production history, the longest injection history, and the most potential for studies of environmental effects. It seems prudent to continue testing this well for two reasons: (1) the large initial costs of well drilling and completion have been met and (2) the data are needed to establish the long-term value of the resource and to induce industrial interest.

Because additional free gas may be obtained in many geopressured aquifers, a matter still under investigation, the Louisiana well offered to DOE by Mob1l o11 Company could be useful in evaluating this concept. All researchers deem the well important to the program and, as stated above, the expensive well drilling and completion have been done by the oil company. The committee estimates that an additional $\$ 3$ million per year is required for testing the current wells, placing the new well in 
production, gathering data and modeling, monitoring for subsidence, and other research attendant to the profect. Therefore, a sustained budget of $\$ 7$ million per year for five years is required to resolve these important technological issues for geopressured geothermal energy use. At that point, it is anticipated that the DOE program might be phased out.

\section{HOT DRY ROCK GEOTHERMAL RESOURCES}

\section{Resource Description}

Unlike hydrothermal or geopressured resources that require both hot rock and indigenous fluids, hot dry rock resources consist of hot rock alone at accessible depths in the earth's crust. The U.S. program has focused on engineering systems in impermeable granitic formations. The primary stimulation technique uses hydraulic fluid pressure to open and propagate fractures from a directionally drilled well, resulting in a fracture network of high effective permeability. This stimulated region is then connected to a second well to complete the underground system. Heat is extracted by clrculating water from the surface, down one well, through the fractured rock network, and up the second well. The heated water than passes through a specially designed power plant on the surface, where electricity or process steam is generated.

The major technical challenges for HDR systems center on engineering the underground fracture network to maximize its heat extraction capacity while minimizing pressure and fluid losses. A large open-fracture labyrinth must be created to allow fluid to sweep efficlently through a significant volume of hot rock. Because heat transport in these systems is inherently limited by the low thermal conductivity of the rock matrix, required rock-fluid heat transfer surface areas and volumes are large.

Heat extraction from HDR reservolis, like other geothermal systems, could be provided continuously, making them well-suited for baseload electric and nonelectric (process heat) applications.

\section{Resource Base}

A major incentive for HDR development is the estimated large magnitudes and widespread distribution of the HDR resource throughout the nation. The HDR resource base ranges from low-grade regions with normal to near-normal thermal gradients of $20^{\circ}$ to $40^{\circ} \mathrm{c} / \mathrm{km}$, to high-grade regions with gradients above $40^{\circ} \mathrm{C} / \mathrm{km}$. The lower-grade resource is distributed more or less uniformly throughout the United States; the higher-grade resource is found mostly in the west, frequently within or

near active hydrothermal systems. However, it is not clear how much of this geothermal resource base qualifies as "dry rock." Several preliminary estimates of the U.S. HDR resource base have been developed in the past 15 years. They were provided by the USGS (Smith and Shaw, 1979; White and Williams, 1975), the Los Alamos National Laboratory 
(IANL) (HDRAP, 1977; Rowley, 1982), and others (Armstead and Tester, 1987). Although the actual numerical values of these preliminary estimates differ, the methods used are similar.

Recent estimates of the higher-grade geothermal resource base suggest that more than 2 percent, or about $1.8 \times 10^{5} \mathrm{~km}^{2}\left(6.9 \times 10^{4}\right.$ square miles), of U.S. Land area should have average gradients in excess of $45^{\circ} \mathrm{C} / \mathrm{km}$ (Kron and Heiken, 1980). This estimate would amount to some 650,000 quads, which is the energy equivalent of 116 trillion bbl of petroleum or 11,600 Prudhoe Bay flelds. The lower-grade resource is 10 to 15 times as large, although what fraction of it would qualify as HDR has not been established.

Based on all estimates, the amount of potentially usable geothermal energy is immense, orders of magnitude larger than the total of all estimated fossil resources. The critical question is how much of this vast geothermal resource base can be recovered within technical and economic constraints. As a point of comparison, usually less than half of the petroleum in an underground reservolr is actually produced. At this stage of HDR resource development, how much of the estimated resource base truly fulfills the criterla for HDR and what fraction is economically recoverable are not known. However, even if only between 0.1 and 0.01 percent of the accessible HDR resource base proves economically extractable, the impact on the U.S. energy supply would be far-reaching. For economic reasons, high-grade HDR resources are likely to be developed first because they require much shallower drilling and significantly lower reservoir development costs.

Thus, given favorable outcomes of further developments, HDR resources could provide a long-term energy supply. HDR could thus be treated as an advanced energy concept not Iimited by the size of the available resource, similar to controlled thermonuclear fusion or solar photovoltaics. For this reason, HDR development should not be regarded as being in competition with the near-term development of hydrothermal or geopressured geothermal resources.

\section{Current Status of Development}

Through 1986, only two mafor fleld programs in the world were almed at developing HDR technology: the U.S. site at Fenton Hill, New Mexico, and the Rosemanowes site in Cornwall, southwest England. The U.S. program has been managed for DOE by LANL since its beginnings in the early 1970s. In 1979, the U.K. program began in the field managed by the Camborne School of Mines primarily under U.K. and DOE sponsorship (Batchelor, 1984).

In 1979; an International Energy Agency (IEA) agreement was adopted to provide for non-U.S. participation in the HDR program at Fenton Hi11. Under the IEA agreement, Kernforschungsanlage-Julich GmbH (representing the Federal Republic of Germany) and the New Energy Development Organization (representing Japan) participated in the project from 1980 to 1986 , providing $\$ 32.5$ million in supporting funds and a number of technical staff assigned to work at LANL. Through fiscal year 1986, U.S. funding support for the project totaled $\$ 105.5$ 
million, most of it used for fleld testing at Fenton Hill. Progress at Fenton Hill has been documented in considerable detail by the IANL team (Dash et al., 1983; Smith et al., 1975; Whetten et al., 1986).

The world's first operating HDR reservoir, with rock temperatures of $185^{\circ} \mathrm{C}$, was completed at Fenton Hill in 1977 (at 2,740 m [9,000 ft] depth). The results of the first phase of testing were positive, clearly demonstrating that heat can be extracted at reasonable rates from a hydraulically stimulated region of low-permeability hot crystalline rock without serious technical and environmental problems.

To extend HDR technology to the higher temperatures and heat production rates required to support a commercial electric generating plant, drilling and stimulation of a larger and hotter HDR reservoir were initiated at Fenton Hill in late 1979. This second phase system was designed to have two directionally drilled inclined holes, with a vertical separation of approximately $300 \mathrm{~m}$, at a $35^{\circ}$ angle of inclination in the stimulated region. Early attempts to connect the wells using hydraulic fracturing were unsuccessful despite the substantial volume of water injected during massive fracturing operations in 1982 and 1983. Microseismic event maps suggest that the stimulated region consisted of a three-dimensional multiple-jointed network rather than a single fracture. With no hydraulic connection with the upper we11, the LANL team decided to sidetrack from it to intersect the seismically active region. This procedure was successful, and in March and April of 1986, the new second phase reservoir was prepared for hydraulic circulation and heat extraction testing. Preliminary testing indicated adequate fluld production temperatures and acceptable water loss rates and flow impedances.

Current plans are to continue testing the redrilled second phase system at Fenton Hill with a long-term (about one year) circulation test. Scheduled for 1987 and 1988, it will characterize steady-state water losses and potential thermal drawdown by monitoring outlet temperatures and using chemically reactive tracers.

The main technical task remaining is enlargement of the two-well HDR reservolr concept to commercial sizes and production rates. Although this task is by no means small, as the field efforts at Fenton Hill and Rosemanowes have demonstrated, it does not require the great technical developments that are frequently necessary before some new energy technologies (such as thermonuclear fusion) can become a commercial reality.

Another useful feature of the heat mining concept is that it can be extended. If success can be achieved with a single pair of wells and an interconnecting network of fractures, then this limited system can be treated as a modular unit to scale up to extract heat from much larger volumes of hot rock. In fact, the first phase reservoir at Fenton H111 served as a module in designing the second phase multiple-fracture system. If reservoir stimulation from an inclined set of wellbores can be achieved as systematically as envisioned, then the technical hurdle of creating and testing a commercial-size system is certainly within reach during the next five years. 
Economic Issues and Projected Costs

Estimates of the economics of HDR resources are not based on long-term information on reservolr performance. Similarly, data on well costs and power plant economics are projections based on certain assumptions. Drilling and completion costs are the most important cost component. Power plant capital costs are comparable to those for binary cycle or multistage flash plants designed for low-salinity, 1iquid-dominated hydrothermal brines ranging in temperatures from $200^{\circ}$ to $300^{\circ} \mathrm{C}$.

Costs for aboveground equipment and piping for direct heat uses are also comparable to those for hydrothermal systems. Two primary factors control the cost of producing electricity or heat from HDR. The first is the grade of the resource, represented by the effective geothermal gradient. It strongly influences drilling costs. The second is the productivity of the reservolr, which is defined by several reservoir engineering characteristics, including inftial fluid temperature, flow impedance, mass flow rates per pair of wells, and the thermal drawdown rate. The initial fluid temperature for a given HDR resource can be selected by drilling to a certain depth with a defined gradient. This fixes the individual well cost. The effective cost per unit of reservolr size is a function of the drawdown rate, which in turn is controlled by how much rock surface area and volume are contacted by the recirculated fluid.

As expected, economic forecasts for HDR show a strong dependence of breakeven electricity prices on drilling costs, assumed reservoir performance, debt interest rates, and anticipated rates of return on equity capital. Based on conditions corresponding to a high-grade HDR resource, such as at the Fenton Hill site, a break-even price of about 50 to 60 mills per $\mathrm{kWh}$ ( 5 to 6 cents per $\mathrm{kWh}$ ) of electricity generated (in 1986 dollars) is predicted. These estimated prices depend strongly on several important performance and economic assumptions, which for this base case include: (1) a $40^{\circ}$ to $60^{\circ} \mathrm{c} / \mathrm{km}$ resource gradient; (2) a reservoir productivity of $75 \mathrm{~kg} / \mathrm{s}$ per pair of wells, with about 20 -percent thermal drawdown in 10 years; ( 3 ) drilling costs two to three times those of petroleum and gas wells of comparable depth (based on data from Fenton H111 and Rosemanowes); and (4) real interest and equity rates of 9 and 12 percent, respectively (Armstead and Tester, 1987).

An Industrial group headed by Bechtel began an independent study of HDR economics for proposed development at Roosevelt Hot Springs, California, in late 1986. In addition, EPRI is providing updated forecasts. Preliminary predictions from EPRI and from a U.R. study (Shock, 1986) show HDR-produced heat and electricity to be competitive with o1l priced at about $\$ 14 / \mathrm{bb} 1$ for heat and $\$ 24 / \mathrm{bb1}$ for electricity. This estimate corresponds to an estimated price (In 1986 O.S. dollars) of $\$ 2.50$ per million Btu for delivered heat, or about 61 mills per $\mathrm{kWh}$ ( 6.1 cents per $\mathrm{kWh}$ ) for electricity. It is important to recognize that these estimates are merely forecasts and are site specific; they are based on the best avallable data on drilling costs, plant capital costs, and projected levels of reservolr performance. As yet, there are no operating geothermal power plants deriving their heat supply from HDR, and the economics of other HDR resources cannot be projected with certainty. 
Environmental Concerns

HDR resource development shares characteristics with other geothermal resource types that affect the environment. However, using the presently envisioned concepts, mining heat from HDR reservoirs will involve the recirculation of water in closed loops. Thus, effluents at an HDR plant site from the periodic purges that may be required will be few. Water loss to the rock formation is a concern, directly as a practical issue of consumption in arid regions and indirectly if it induces seismicity. The magnitude of seismic risk depends strongly on the geological setting of the HDR system and on how heat is mined from the reservoir. Field evaluations so far lead to an optimistic outlook. Water loss rates have been controlled using downhill pumping and other reservoir pressure management strategies. Further, the lack of induced seismic hazards under long-term pressurized circulation in several fractured HDR reservoirs in the United States and the United Kingdom is encouraging. In any development situation, seismic risk would be addressed by conducting a comprehensive geotechnical assessment of the proposed site and by extensive seismic monitoring during development and testing.

\section{Feasibility and Impediments to Growth}

Although much has been accomplished in demonstrating the technical feasibility of HDR, several major issues must be resolved to reduce the real and perceived risks of developing commercial HDR ventures at other sites. These issues, primarily concerning englneering of the underground system, can be divided into the following categories:

Driling and completion. Improvements in conventional and directional drilling techniques that lead to increased penetration rates and reduced costs would provide significant incentives for commercial HDR developments. Techniques and hardware are needed to isolate and control flow in multiple-fractured systems.

Reservolr stimulation. Improvements are needed for hydraulic fracturing in low-permeability reservolr rocks to yield interlinked injection and production wells with sufficient swept heat transfer areas and volumes to support commercial heat production rates for 10 to 30 years. Improved hydraulic fracturing requires improved geophysical diagnostic and analysis techniques for understanding in situ rock behavior.

Long-term reservoir performance. A commercial-scale stimulated HDR reservoir needs to be operated for one to two years to demonstrate reservoir performance and verify models being developed to predict performance. By April 1987, only limited testing of the second phase 
reservolr at Fenton Hill had occurxed. Although the results were positive, it is much too early to predict long-term performance. Further, the observed growth in reservolr volume with time needs to be better characterized.

\section{Conclusions and R\&D Budget Recommendations}

Based on the preceding discussion, the following conclusions were reached:

- At this stage of the development, it is not known how large a fraction of the vast HDR resource could be economically converted into useful energy.

- HDR-produced heat and electricity are projected to be economic for some sites, given reasonable increases in petroleum prices and successes in reducing reservolr and drilling costs.

The following discussion and recommendations for DOE'S R\&D are based on the consensus of the Advanced Resources Program panel that reviewed the HDR components of DOE's LANL geothermal program in October 1986 (see Appendix G).

Although the current DOE program is well-managed, with reasonable and important technical goals directly addressing the issues raised in the previous section, program funding for HDR development at $\$ 8$ million for fiscal year 1987 is at a critical threshold level for supporting current field efforts at Fenton Hill. There are no contingency funds if problems should develop at Fenton Hill and no funds for inftiating field efforts at another site. To stimulate industrial development, DOE should be prepared to continue supporting HDR resource R\&D through the demonstration stage ( 5 to $10 \mathrm{MWe}$ ) at Fenton Hill and at a second site.

Over the past 14 years, about $\$ 106$ million of U.S. government funds and $\$ 32.5$ million of combined West German and Japanese funds have been invested in HDR resource development, almost exclusively at the Fenton Hill site. As shown in Table 2-1, the budget for HDR has declined steadily from a high of $\$ 20$ million in 1980 to its current value of $\$ 8$ million in 1987. These funding cuts are further exacerbated by the recent loss of West German and Japanese financial support.

The specific program and budget recommendations for DOE HDR resource development are as follows:

- Fenton Hill testing. The second phase program at Fenton Hill should be completed with up to two years for reservoir testing and two years for analysis and modeling, documentation of results, and technology transfer. DOE commitment should end by 1991 and the site turned over to industry for second phase power plant development.

o Second site development. An industry partner should be secured for development of a second site. LANL technical staff should be Involved to provide field engineering expertise as required. Support should be continued through the demonstration stage of a 5- to 10-MWe power plant. 
Estimated required budgets for these two efforts over the next five years are shown in Table 2-3. With budget cuts to $\$ 8$ million in fiscal year 1987 and the loss of technical personnel and $\$ 5$ million in funds per year provided by West Germany and Japan, the program at Fenton Hill has been greatly weakened. Given the considerable investment of funds for HDR resource development and the promising results from preliminary testing of the second phase reservolr, it would be fiscally inappropriate not to see the project through this important field test. Contingency funds should be added to the budget for reworking the EE-2/EE-3 wellbores, if needed, since their operability is prerequisite for the flow test.

Because private commercialization of the HDR resource is the ultimate DOE objective, assuming favorable technical and economic factors, alternate site development will be required to establish sufficient confidence in the technology and costs to warrant private investment. Industry-government cofunded ventures should be vigorously pursued, but they may not be feasible in today's economic climate. Given HDR's potential critical role in U.S. long-term energy supply, DOE should be prepared to fund $R \& D$ efforts at the second site.

\section{MAGMA ENERGY RESOURCES}

\section{Resource Description}

Magma is molten or partially molten rock in the crust of the earth at depths usually greater than $3 \mathrm{~km}$ and at temperatures between $650^{\circ}$ and $1,200^{\circ} \mathrm{C}$. At these temperatures, the material is a mixture of liquid crystalline phases. Proposed magma energy extraction systems require drilling boreholes into convecting magma. The thermal stresses created in magma solidifying around the cooled borehole are belleved to be sufficient to cause fracturing. By circulating a heat transfer fluid though the fractured and solidified magma, energy would be extracted from the magma.

\section{Resource Base}

A framework for estimating the spatial dimensions and heat content of magma chambers underlying recently active volcanic centers was provided by Smith and Shaw (1979). Based on their research, USGS published an estimated U.S. resource base of 50,000 to 500,000 quads of energy contained in magma chambers at temperatures above $600^{\circ} \mathrm{C}$ and at crustal depths in the range of 2.5 to $10 \mathrm{~km}$. In spite of the uncertainty of these estimates, they indicate a large potential for magma energy. A significant portion may be economically recoverable. Sites have been identified in the western states where 30-year, multi-MW power plants could be supported by shallow magma bodies. Although considerable technology must be developed, magma resources are potentially significant for future U.S. energy supplies. 
TABLE 2-3 Committee Budget Recommendations for DOE HDR Resource Research and Development (in millions of dollars)

Fiscal Year

\begin{tabular}{lcccccc} 
Program Element & 1987 & 1988 & 1989 & 1990 & 1991 & 1992 \\
Fenton Hill testing & 8 & 10 & 10 & 9.0 & $<5$ & 0 \\
Second site development & 0 & 2 & 15 & 15 & 25 & 15 \\
Total & 8 & 12 & 25 & 24 & $<30$ & 15 \\
\hline
\end{tabular}




\section{Current Status of Development}

During 1983, the Geothermal Technology Division of DOE Inftiated the Hagma Energy Extraction Project. This R\&D program followed a seven-year scientific study funded by the DOE Office of Basic Energy Studies that demonstrated the scientific feasibility of the magma energy concept (Colp, 1982). Early research had been directed at a geophysical understanding of the location of magma bodies, the drillability and stability of boreholes at temperatures approaching rock melt, the chemistry of magmas, and heat transfer processes.

At the conclusion of the seven years of research, the energy extraction concepts were demonstrated by driliing into the molten zone of Kilauea IkI lava lake, Hawali, emplacing energy extraction hardware into the borehole and operating the system over five days (Hardee et al., 1981). The energy extraction hardware consisted of an open heat exchanger system in which fluid was circulated through the solidifled magma. This system appeared to promise high energy extraction rates.

The present magma energy program is focused on the U.S. continental magma systems. The magma project, managed by researchers at Sandia National Laboratories (Dunn et al, , 1987); is addressing resource location and definition, drilling into magma, magma characterization and materials compatibility, and energy extraction. The objective of magma energy research is to drill into an active crustal magma body and conduct an energy extraction experiment. A location for the initial experiment has been selected in Long Valley volcanic crater in east-central California, where a reasonably shallow potential magma body has been Identified.

\section{Economic Issues and Projected Costs}

Estimates of the costs of magma energy exploitation can be based only on reasonable projections. Of all the geothermal energy resources, magma has the least operational experience. Systems analysis indicates that the rate of energy extraction is the most important factor for economic use of magma energy. More specifically, it is the rate at which electricity can be generated from a magma well that is the major factor. Because all analyses are now based on several major assumptions, it is not possible to determine whether magma energy would be cost competitive with other energy resources. Current best estimates using detalled models of drilling, completion, surface conversion, and energy extraction are that magma-based electricity prices would be in the range of 80 to $110 \mathrm{mills} / \mathrm{kWh}$ ( 8 to 11 cents/kWh) (Carson and Haraden, 1985). These prices are somewhat higher than current prices of 50 to $70 \mathrm{mills} / \mathrm{kWh}$ for fossil fuels and 60 to 85 $\mathrm{mills} / \mathrm{kWh}$ for hydrothermal geothermal resources. However, environmental, regulatory, and political constraints have driven prices for new nuclear plants above the magma estimates. As the technology is developed, the estimates should be improved and updated regularly. The technology developed in the magma energy program will surely benefit the evolving geothermal industry as a whole. 


\section{Environmental Concerns}

The environmental issues associated with development of magma resources are similar to those for all geothermal resources. Thus, they are not reiterated here.

\section{Feasibility and Impediments to Growth}

The factors most critical to the technical and economic feasibility of magma energy extraction are well cost, well productivity, and reservoir iffetime. In particular, if it is economically and technically possible for a magma well to cost less than a half million dollars per megawatt of electrical capacity that it delivers, and if the well can be made to be productive for at least 10 years, magma-based energy would very likely be attractive.

\section{Conclusions and R\&D Budget Recommendations}

Based on the preceding discussion, the following conclusions and recommendations were reached:

- The resource base of temperatures above $600^{\circ} \mathrm{C}$ provided by magma energy is extremely large. Nevertheless, technical exploitation is a long-term future possibility.

The DOE magma energy program should focus on developing techniques and methods for accomplishing resource location and spatial definition. Additionally, the program should be directed toward determining the engineering feasibility of extracting energy directly from shallow magma bodies and toward providing sufficlent data for industry to evaluate its commercial potential. The program must develop drilling technology to reach the magma resource and completion technology to use the well for an extended period. It must also develop an energy extraction procedure that allows long-term efficient extraction of heat throughout a well's lifetime. The ultimate tests of extraction processes will be carrled out by drilling into and verifying the existence of an active crustal magma body. This work might be done through the borehole proposed by Sandia for the Long Valley volcanic crater (in light of recent geophysical studies it is not yet clear that this is the optimal site). Current experimental and analytical investigations will be used to guide these field experiments and for data interpretation and evaluation. Recommended R\&D levels of effort for accomplishing these goals are given in Table 2-4.

\section{DISCUSSION, CONCLUSIONS, AND RECOMMENDATIONS}

The large U.S. geothermal resource base indicates that even if only a small fraction can be economically converted into useful energy, it can be an important future energy source. This point is especially meaningful 
TABLE 2-4 Committee Budget Recommendations for DOE Magma Energy Resource Research and Development (in millions of dollars)

Fiscal Year

\begin{tabular}{lccccc} 
Program Element & 1988 & 1989 & 1990 & 1991 & 1992 \\
$\begin{array}{l}\text { Experimental and analytical } \\
\text { Investigations }\end{array}$ & 0.5 & 2.0 & 2.0 & 3.0 & 30 \\
$\begin{array}{l}\text { Trial borehole } \\
\text { Total }\end{array}$ & 0.8 & 3.0 & 1.0 & 4.0 & 2.0 \\
& 1.3 & 5.0 & 3.0 & 7.0 & 5.0 \\
\hline
\end{tabular}


insofar as the prices of other energy sources increase. Geothermal energy is Inherently a secure energy source for the United States; it can be a baseload alternative to conventional fossil and nuclear power plants. Further, it can enhance air quality by reducing emissions from the burning of fossil fuels. Electric power is commercially produced from some hydrothermal resources, but commercialization of HDR, geopressured, and magma resources has yet to be demonstrated. Most environmental problems for hydrothermal power plants have been resolved, but some remain. The committee concluded that careful development and engineering should solve anticipated environmental problems.

Given the current U.S. energy situation, Industry will continue developing technologies for hydrothermal resources. Because of the long-term horizon for their economic viability, Industry will not support technical R\&D for geopressured, HDR, and magma geothermal energy resources.

In the current DOE Geothermal Technology Program, HDR R\&D dominates the budget at 38 percent; 19 percent is allocated to geopressured R\&D and 14 percent to hydrothermal research. Only $\$ 1.4$ million is earmarked for drilling technology, which cuts across all geothermal technologies. Another $\$ 1.3$ million was set aside for reservoir engineering studies in the Salton Sea Scientific Drilling Project. The magma energy extraction program was reduced from $\$ 1.7$ million in fiscal year 1986 to a half million in fiscal year 1987. The major areas of R\&D are continuing, but the reduced hydrothermal research budget significantly affects these important projects.

Development of geopressurized brines requires improved understanding of reservolir size, dynamics, and productivity. Predictive models applicable to geopressured wells, under development for some time, require long-term flow tests and verification. Production well tests are encouraging, indicating that reservoir pressures are maintained considerably above levels predicted with conventional reservolr engineering techniques. However, before the long-term performance of a reservoir can be predicted on the basis of short-term tests, the driving forces that sustain the pressure must be confirmed.

The long-term environmental acceptability of geopressured resource exploitation must also be proved through long-term well tests before widespread development can be expected. Loulsiana, for example, is already losing 50 square miles of coastline per year through natural subsidence, and additional subsidence attributable to geopressured wells probably would not be tolerated.

Similarly, verification of long-term reservolr performance is a principal technical consideration for HDR technology, along with control of water loss and circulation impedance and other technical features. For this technology to attract commercial development, the successful creation and control of a multiple-fractured reservoir of at least 20 to 35 MWt with a projected life in excess of 10 years must be demonstrated.

Important field tests at the Fenton Hill site in New Mexico are under way.

Magma energy extraction R\&D, new in advanced geothermal technology, has received only modest funding and is still in an early stage of development. Magma is the most difficult form of geothermal energy to 
access, and the potential energy extraction rate is the controlling factor in its use.

Stable and well-funded R\&D is needed to continue to determine and improve the scientific, engineering, and economic feasibility of using energy from all geothermal resource types. The short-term goal of the DOE R\&D should be to improve technical performance significantly through research on second-generation technologies in order to locate, develop, extract, and convert geothermal energy from liquid-dominated hydrothermal reservoirs. Improved performance is expected to increase markedly the number of U.S. hydrothermal reservolrs from which industry can produce energy in the near term. These technologies are thus fundamental to a balanced DOE R\&D program.

The longer-term goal of R\&D should be to determine whether other types of geothermal resources (geopressured, HDR, and magma energy) are viable future energy sources and to continue to provide industry a base for evaluating the economics of producing and using these forms of energy. Because of their economics, it is unlikely that these resources will attract industry involvement in the short term. Given scientific and technical improvements from a continuing, well-funded federal R\&D program, these four types of geothermal energy together offer a significant potential contribution to the economic and energy security goals of the United States.

Hence, the following conclusions were reached:

- The current oversupply and relatively low prices of hydrocarbon fuels, especially of petroleum, are short-term fluctuations within a long-term supply shortage. Given the large U.S. geothermal energy resource base and the potential for converting even a small percentage of this base into economically useful energy, developing U.S. geothermal resources may be an important contribution to U.S. energy self-sufficiency.

- In the near term, industry will continue to invest in technologies for exploiting hydrothermal resources. It will not invest in development for the longer-term resources of geopressured, hot dry rock, and magma energy. Because of the critical importance of maintaining various energy supply options for the future, a viable and stable research program for these longer-term geothermal energy resources is necessary.

- In the near term, the use of hydrothermal geothermal resources will exceed that of other geothermal resource types. Improving utilization technologies should make many of the presently uneconomic resources competitive. Power production from geopressured and hot dry rock resources is thought to be economic at some sites, although using these resources is a longer-term possibility. Magma energy technologies are too uncertain now to make economic projections.

- Significant strides in environmental controls for hydrothermal energy systems have been made since their early development." There has not been enough operating experience on other types of geothermal systems. Environmental problems remain but are site specific and are thought to be remediable through study, engineering design, and construction practices. 
- The geographical distribution of geothermal energy resource fields is a constraint to use. The new high-temperature superconducting materials and their use for electrical transmission lines may alleviate this constraint.

- Institutional barriers are not a major constraint to geothermal energy development.

- Stable and adequately funded DOE R\&D is needed to determine and improve the scientific, engineering, and economic feasibility of using energy from all types of geothermal resources. Short-term R\&D in the DOE geothermal technology program should be directed toward improved technologies to locate, develop, extract, and convert geothermal energy from liquid-dominated hydrothermal resources.

- Long-term DOE R\&D should be directed toward determining the viability of geopressured, $H D R$, and magma energy resources for future energy production. Expenditures in these areas can decrease in the future as commercial viability is or is not indicated and industry accordingly begins to participate.

The following recommendations were therefore reached:

- The DOE Geothermal Technology Program should be funded over a fiveyear period at a somewhat higher and stable level to maintain viable R\&D programs for both near-term and long-term geothermal resources (see Table 2-5). The funding recommended for each geothermal resource category is at a critical minimum level, and would decline over the period as anticipated research goals are met (see Tables 2-2 to 2-4). 
TABLE 2-5 Committee Estimates of the DOE Budget Needs for Geothermal Resources Research and Development (in million of dollars)

\begin{tabular}{lccccc}
\hline & \multicolumn{5}{c}{ Fiscal Year } \\
\cline { 2 - 6 } Program Area & 1988 & 1989 & 1990 & 1991 & 1992 \\
\hline Hydrothermal & 16.7 & 16.7 & 16.7 & 14.2 & 14.0 \\
Geopressured & 7.0 & 7.0 & 7.0 & 7.0 & 7.0 \\
Hot dry rock $\underline{\text { a }}$ & 10.0 & 10.0 & 9.0 & $<5.0$ & 0 \\
Magma energy & 1.3 & 5.0 & 3.0 & 7.0 & 5.0 \\
Total & 35.0 & 38.7 & 35.7 & 33.2 & 26.0 \\
\hline
\end{tabular}

a Does not include development of a second site (see Table 2-3). Funding levels for each category are at a critical minimum. 
GOVERNMENT, INDUSTRY, AND UNIVERSITY COOPERATION

IN GEOTHERMAL RESOURCE DEVELOPMENT

In the United States and other countries, cooperation among government agencies, industrial companies, and universities has taken different forms over the years. Many models of such cooperation exist, and they are described here. Certain characteristics of cooperative organizations strongly influence their ability to meet their goals. This chapter examines these characteristics as they apply to developing both near- and long-term geothermal resources.

Cooperative arrangements were discussed at length at the workshop sponsored by the committee (see Appendix B). Presentations by the speakers and comments by the advisory group helped the committee in its deliberations.

\section{BACKGROUND}

Nearly all models for cooperative research and development (R\&D) the committee reviewed have common elements, largely because organizations brought together to effect this R\&D have had to wrestle with common issues. The committee recognized that even though most cooperative organizations experience like problems, important differences often determine successes and fallures. Sometimes the differences are obvious and at other times they may be subtle. For example, the quality of dialogue among participants may be critical to successful and sustained operation.

Each participant in a cooperative effort may have quite different motivations. A federal agency may attempt to carry out a congressional mandate through a cooperative mechanism involving industry and universities. A private company may attempt to accelerate the development of a needed technology and be willing to share ownership of the technology in return for early access. A university faculty member may be seeking funding of a research project in return for sharing ownership of a patent with the sponsors. 
In the United States, there is currently a strong interest in promoting cooperative government-industry-university relationships. This interest appears to be driven by several factors: tightened or reduced federal and industrial R\&D budgets, aggressive foreign competition strengthened by increased government-industry cooperation, a need to share expensive facilities and equipment, changes in the antitrust laws and their interpretation that facilitate cooperation among private companies, and a belief prevalent in many circles that the results of university research often languish in the laboratory too long without being applied.

The major attraction of cooperation is that participants can share the costs and the financial risks. In addition, participants are exposed to a broader technical base. Joint ventures among private companies, as a means for the companies to take on projects that would be too large or risky for them individually, are common and well-accepted. By cooperating in R\&D, government agencies and private companies can generally leverage their investments and participate in efforts of broader scope than they can afford individually. Collaboration in R\&D can also lead to shared access of specialized facilities and equipment that a single party cannot afford.

With Increasing national concern about $0 . S$. competitiveness, there is the growing bellef that more commercial advantages should flow to U.S. companies from public and private investments in research. By the same reasoning, involvement of industry in university-based research should increase the relevance of research to industry needs. Several notable federal R\&D programs now require some industrial participation, at least In planning and technology transfer, in the university-based R\&D centers that they fund (see the following sections on government-industry and government-industry-university cooperation).

Another advantage for participants in cooperative organizations is that the interchange improves understanding of activities in other laboratories, subject of course to reasonable protection of proprietary interests. Such collaboration seems to have improved communication among managers and professionals involved in the joint efforts.

Even so, tradeoffs arise from participating in cooperative organizations. Participants must share control and ownership of intellectual properties, where applicable. One potential problem is that cooperative efforts may unduly expose a company's proprletary information to its competitors. In addition, a cooperative organization may simply create another layer of bureaucracy between the sponsoring and performing parties, often adding unnecessary overhead.

The chapter ends by examining the feasibility of two cooperative arrangements. They concern the near-term technical needs of hydrothermal resource development and an improved scientific basis for developing longer-term geothermal resources. 


\section{EXAMPLES OF COOPERATIVE RELATIONSHIPS}

Numerous organizations bring industry, universities, and government together to pursue joint R\&D. Such arrangements have been described in detall (National Research Counc11, 1986a,b; Gray and Lorand, 1986), but a few of the more exemplary will be outlined here. The discussion is limited to consortia for conducting engineering $R \& D$ and does not include either medical or agricultural R\&D efforts.

\section{Industry-Industry Cooperation}

The Microelectronics and Computer Corporation (MCC), the Electric Power Research Institute (EPRI), and the Gas Research Institute (GRI) are we11-known. All are corporations, with a board of directors, that set research goals, outline projects, and have permanent staffs to arrange for research. For some, research is arranged with both public and private organizations; others, such as MCC, have internal resources for conducting research. Its source of funds is industry. In all cases, industry is the principal beneficlary of the research. However, EPRI and GRI are funded by the electric and gas utilities, respectively, through a rate structure that allows a part of the Income earned by utilitles to be diverted in support of these institutes.

\section{Industry-University Cooperation}

Industry-university cooperation generally falls into three categories. The first is the traditional "Industry affiliates" program, as ploneered by MIT, in which companies with common research interests pay as much as $\$ 25,000$ to $\$ 50,000$ per year to help support a research program of fairly limited scope, for example, on composite materlals. In return, sponsors are kept informed about the research. The scope and direction of research are largely determined by a professor or a group of academic researchers.

Another traditional mechanism is a single company's contracting with a university for research of specified scope or Its making a grant to a university for research in an area of mutual interest.

A third type of industry-university cooperation is exemplified by the Semiconductor Research Corporation (SRC), In which a group of companies interested in a well-defined research area form a corporation to support university research. The corporate board provides funds and with outside assistance decides on projects and centers to be supported.

\section{Government-Oniversity Cooperation}

Government-university relations are well-established; many cooperative organizations have been operating for up to 40 years. They range from large laboratories for the Department of Defense, such as the Johns Hopkins Applied Physics Laboratory and Pennsylvania State University's 
Applied Research Laboratory, to companies with small contracts for specific studies.

There are many other examples of government-encouraged cooperative efforts, such as the National Science Foundation (NSF) support of laboratories or scientific projects directed by a consortium of universities, for example, the Oniversity Corporation for Atmospheric Research.

Government-university cooperation represents all kinds of financing and project direction. In military contracts, research is usually 100 percent government financed, and the direction of the research, at least in general terms, is usually defined explicitly. In NSF contracts and grants, on the other hand, the university is expected to make a financial contribution, but the academic researchers have much more scientific and technical control.

\section{Government-Industry Cooperation}

Government contracts with a single company require no elaboration, but there are also arrangements between government agencies and a consortium of companies. One example of this arrangement is the Geothermal Drilling Organiration (GDO)-DOE agreement, which is discussed in detall later. Another example is the cooperation between the National Bureau of Standards' Advanced Manufacturing Research Facility and its industrial cooperators. In these arrangements, funding often comes from both government and Industry, which together decide the projects to support. The projects may be carried out in either industrial or government facilities.

\section{Government-Industry-University Cooperation}

The third and generally most complicated type of arrangement involves government, industry, and universities. Nevertheless, such arrangements are now in favor because it is belleved that they can concentrate on matters of national importance and can move research results more quickly into the market.

Examples Include the Engineering Research Centers and cooperative R\&D centers sponsored by NSF. Located at universities, the centers must have a significant source of outside funding (e.8., private companies and state governments). Although the direction of the research projects is the responsibility of the university researcher, industrial advice is sought in guiding the program toward satisfying industrial needs.

\section{Role of Limited Partnerships}

The committee also considered the possible role of limited partnerships in either short- or long-term geothermal resource development. Because of the recent changes in the U.S. tax law, the attractiveness of the R\&D limited partnership (RDLP) to raise capital for R\&D has diminished 
considerably. The committee understands that, beginning in 1987, the tax benefits for investors from RDLPs w111 be greatly reached (Peter and Fusfeld, 1986).

Consequentiy, decisions by private investors to engage in RDLPs are now driven by a project's inherent profit potential and also by the convenient legal structure of an RDLP, rather than by tax advantages (Peters and Fusfeld, 1986). Given the present (and likely near-future) energy price structure, the committee concluded that such partnerships in geothermal R\&D will not offer enough profit potential to serve as a new source of R\&D funding.

\section{QUESTIONS ABOUT COOPERATIVE RELATIONSHIPS}

On examining the variety of cooperative relationships organized to plan, manage, and perform R\&D, the committee found that all appear to have addressed common issues. In the design of a cooperative R\&D organization, confronting these issues is essential to an operationally successful cooperative relationship.

The committee identified 15 specific issues that must be resolved:

1. Goals and obfectives. Which of the partners determines the organization's goals and objectives? Are they determined by the industrial, government, or university partner? How broad or narrow are the goals and objectives?

2. Research agenda and program. How is the research agenda determined? Who is involved in this process? Does the government partner actually set the agenda or does it just have the right of approval? If companies provide funds, is it their agenda? What is the role of academic researchers, who are also often partners, in agenda-setting?

3. Financing. How is the organization financed on a short-term basis? What is the role of membership fees? Is there base financing as well as project financing? How is the "overhead" infrastructure financed? What are the relative roles of private and public financing? How much should come from the federal government, Industry, and state government?

4. Program and project management. Who is responsible for managing the organization's programs? Who manages the projects? Are these tasks the responsibilities of the organization, the funding agency, or the research partners?

5. Ownership and use of intellectual property. Who owns the results of research that have tanglble market value (such as patents, data bases, and software)? Is income from the sale or use of intellectual property shared, and if so, how? How is proprietary information handled? What rules govern lead time and dissemination of research results through publication?

6. Research performance. Who actually performs the research, universities, industry, or government? Must the performers be members of the cooperative organization? Are the performers staff members of the organization, or is their work done under contract? 
7. Evaluation. How is the general performance of the organization evaluated? Who carries out this evaluation, using what criteria? How is evaluation of proposed research accomplished and performers selected? Are these tasks done by peer or management review? How is the quality of research performance measured? How is responsibility delegated?

8. Accountability. To whom is the cooperative organization accountable, government, industry funders, or a board selected by the funders?

9. Collaboration and cooperation. Is interinstitutional collaboration desired? If so, how is it brought about? What is meant by collaboration as opposed to cooperation on research projects?

10. Antitrust implications. Are antitrust implications raised by the organization's structure, operations, or meetings? Are there any monopoly implications? That about the appearance of monopolistic practices?

11. Institutional structure. How is the cooperative relationship structured? Does it have to be a new organization, or can it rely on an existing one? Is the organization an independent cooperation, joint venture, or partnership? What kind of board of control is appropriate, and how is it appointed? What are membership requirements? Is there a chlef executive officer for the organization?

12. Administrative support. Is a new administrative infrastructure required for the organization, or can an existing infrastructure be used to provide administrative services? How are administrative costs (overhead) accounted for and pald?

13. Program integration. How are performance and results of the organization's research activities transferred into the life of cooperating institutions?

14. Employment factors. How are officers and staff members employed, on a short- or long-term basis? Do they have to sever their ties to preceding employers?

15. Educational implications. What are the opportunities for or constraints on employees with respect to continuing education and training?

\section{CRITERIA FOR SUCCESS IN COOPERATIVE RELATIONSHIPS}

In general, the committee concluded that success and fallure in cooperative organizations are rooted as much in the subtleties of the relationships as in the structures, in the quality of the dialogue among participants, and in the degree of commitment they bring to achieving the goals of an organization. However, the organization and 1ts structure will either facilitate or retard progress. Thus, several criterla stand out as critical and require resolution through design:

- Where does program direction and control reside? If the goal is commercial application, then the industry partners must control program direction. If increasing the knowledge base is the goal, then the university partner must control program direction. To help understand the broad range of approaches that can be taken on program direction, the 
committee considered the examples in Figure 3-1, which shows a selected number of existing cooperative organizations. At the extreme top is the MCC, which is funded and controlled exclusively by private industry. EPRI and GRI are predominantly controlled by Industry, but because of the regulatory review process, their programs are also influenced by government and universities. At the lower right corner, government laboratory cooperatives have varying degrees of outside direction. As one example, the National Bureau of Standards' Advanced Manufacturing Research Facility receives substantial funding from the U.S. Navy, but it also involves a significant number of private companies.

In the lower left corner are the cooperative university programs, such as the National Sclence Foundation Centers mentioned earlier. Even though the majority of the funding for these centers comes from government, control is exercised largely by faculty researchers. The influence of industry varles, depending on both the fraction of support provided by industry and the working relationships between industrial and university players.

- Is there a sufficlently long-term commitment by the partners? Without a multiyear commitment to the organization and its goals by participants, long-term planning is impossible. Commitment in this case is not meant to imply long-term financlal commitment, because this is legally or structurally impossible for some participants. However, in its more subtle meaning, commitment to a cooperative relationship implies the desire by participants to stay with it. It also suggests the bellef that the success of the Individual participating organizations is related to the success of the cooperative organization. The implication, then, is a long-term financial commitment.

- Are adequate resources avallable to achleve the obfectives (or can these resources be developed)? Objectives unachlevable owing to insufficient resources are the fastest and surest way to destroy relationships.

- Can and do the participants communicate well with one another? For an arrangement to succeed, open, unambiguous communication is an essential ingredient. If the partners do not start with basic trust and experience in communicating with one another, then the structure and operations of any partnership will not work. Good, strong leadership can help overcome communfcations problems, but long-term success is tied to cooperation through open communication among participants.

\section{ALTERNATIVE APPROACHES TO COOPERATIVE RELATIONSHIPS}

Because of current economic conditions and the state of development in the geothermal industry, the committee concluded that it is unrealistic to expect that private industry can or will fund most of the R\&D needed in this area. The short- to mid-term profit potential is not sufficlently high, and the industry is not mature enough to generate the profits needed to support significant R\&D. Industry-unfversity cooperation such as an industry affiliates program or the SRC are, thus, unlikely in geothermal 


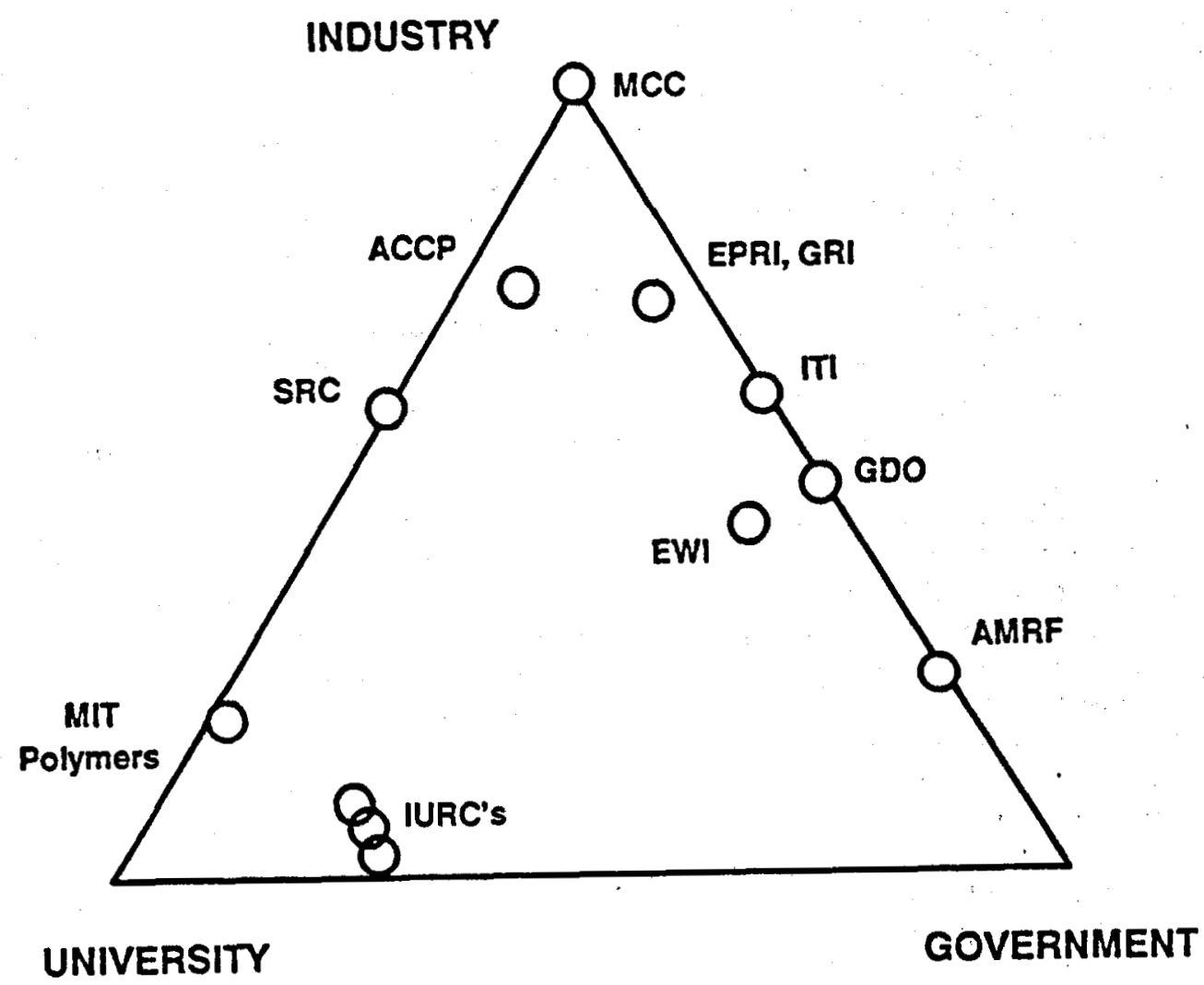

ACCP

Advanced Ceramlcs \& Composites Partnershlp, Midwest Technology Development Institute

AMRF Advanced Manufacturing Research Facility, National Bureau of Standards

EWI Edison Welding Institute (Ohio)

EPRI

GDO

Electric Power Research Institute

GRI Geothermal Drilling Organization

Gas Research Institute

ITI

IURCs

Industrial Technology Institute (Michigan)

Industry University Research Centers, National Science Foundation

MCC Microelectronics and Computer Corporation

MIT/Polymers Massachusetts Institute of Technology, IURC

SRC

Semiconductor Research Corporation

FIGURE 3-1 Program Control of Cooperative R\&D Organizations. 
RED. Nor could an organization like MCC or EPRI be supported; limited partnerships do not offer enough profit potential to serve as a new source of R\&D funding. Consequently, the government must continue to sponsor R\&D if substantial progress is to be made.

Government-Industry Cooperation

for Near-Term Resource Development

After reviewing varlous cooperative mechanisms for near-term geothermal resource $R \& D$; the committee concluded that one model stood out above all others--the existing cooperative agreement between the Geothermal Drilling Organization and the Department of Energy (DOE).

Though the objective of the agreement is presently limited to developing technology for reducing the cost of drilling, completing, and logging geothermal wells in the short-term and the organization is not without shortcomings, GDO is an apparently successful operation that responds to most issues ralsed earlier and generally meets the criteria for success.

GDO membership is open to all (businesses, universities, Individuals, and others). It has 18 members, each of whom paid an initial $\$ 500$ membership fee. The organization sets priorities for short-term R\&D projects and seeks funds from its members as well as matching funds from DOE. Each project is funded by individual firms and DOE. For equipment that is developed, the funders have priority use for one year and royalty-free licenses thereafter. Anyone may use the equipment after the first year.

Sandia National Laboratories, acting as project administrator for GDO and DOE, contracts with outside performers project by project. Three projects are now under way and more are being developed. The principal elements of this arrangement are the following:

- Projects have well-defined, short-term objectives.

- GDO members select the projects, if any, they wish to support.

- DOE reserves the right to select which GDO-proposed projects it wishes to support.

- DOE support for projects can be approved through a prior legal agreement ("Project Letter Agreement") without having to renegotiate each time. This agreement is the heart of the GDO-DOE model.

- All funds (both industry and DOE) flow into Sandia National Laboratories, which serves as the contracting agent for the agreement.

- The projects are performed by outside parties under contract to Sandia.

The committee concluded that this arrangement is a successful and effective model that should be modified and then adapted to cover the wide range of short- through mid-term cooperative geothermal development activities. The committee is aware of several other organizational initiatives to rationalize government-industry geothermal development projects. In light of the success of the GDO model, the committee 
recommends expanding its charter from "geothermal drilling" to "short- to mid-term geothermal development." Correspondingly, the organization's name should be changed from the Geothermal Drilling Organization to the Geothermal Development Organization. The committee recommends consideration of other changes in structuring the new GDO:

- Organizing as an independent membership corporation capable of owning assets

- Developing a board of directors and officers that does not include DOE or DOE contractors (as Sandla does)

- Adding a small permanent staff, including an executive director, to serve as a secretarlat and fiduclary agent.

\section{Government-Dniversity Cooperation \\ for Research on Long-Term Geothermal Resources}

In considering alternative cooperative mechanisms for research on long-term geothermal resources, the committee concluded that several facts must be confronted. Industry will probably continue to invest in near-term hydrothermal resource development, but they will probably invest little, if any, for research on long-term resources. In particular, there is a low probability of Industrial funding for geosclence research (and related technologies) on geopressured, hot dry rock, and magma geothermal resources.

Because of the critical importance of ensuring various future energy supply options, a minimal long-term research program on potential sources, such as geopressured, hot dry rock, and magma resources, must be pursued.

Drawing in part from the review of the GDO-DOE agreement and from assessment of other cooperative organizations, the committee concluded that one approach for long-term government-university cooperative research should be considered a promising policy option.

The first element of this government-university cooperative relationship would be the establishment of a Geothermal Research Organization (GRO) composed of researchers interested in the scientific and technological issues relating to long-term geothermal resources: geopressured, hot dry rock, and magma resources. Even though GRO's main purpose Initially would be to advise government agencies and formalize communication among primarily academic researchers, GRO should be incorporated. Incorporation could occur if and when GRO decides to own intellectual properties or act as a financial agent for participants.

Second, GRO participants, in cooperation with government funding agencles, would agree to develop a research agenda. This agenda would include both a multiyear program plan and specific research projects. Within the framework of this agenda, the researchers, individually or in collaboration, would then submit proposals to the contract administrator, who in turn would subject the proposals to rigorous peer review and ranking for importance and timeliness.

Third, DOE would allocate part of its long-term research budget to these efforts on a sustaining basis. Funds would be transferred to the 
contract administrator for disbursement to GRO participants. Sandia Laboratories could, of course, be one contract administrator, although other DOE laboratories and operational organizations could do so. The committee decided, however, that the contract administrator should not perform any research funded through this mechanism, that is, should not compete with universities and other eligible performers for funds.

Fourth, both DOE and the GRO participants would work together to identify other funding sources, primarily from the federal government, who might be interested in investing in program areas and projects compatible with a particular agency's mission. Candidates include the NSF, U.S. Geological Survey, and Department of Defense. As a practical matter, such efforts could be funded by a consortlum of government agencies, an approach that has worked for certain interdisciplinary problems in the past. One specific mechanism considered by the committee was the funding of such work through an Engineering Research Center sponsored by NSF and funded by several federal agencles. For example, DOE and other agencies could transfer money to NSF for the support of such a center. The committee noted that NSF would have to be flexible in its review of a GRO-endorsed center, providing specifically for involvement of a number of universities in the center's activities.

It is even possible that, if the profit margins of the large oil companies improve with increased oil prices, some oll companies might invest in basic geoscience research of general relevance to oil and gas exploration and production. A geothermal-oriented research center, which encourages industry involvement, might attract such funding.

Further, a "geothermal coordination group" could be composed of an equal number of representatives from the GDO and GRO. The purpose of this group would be to keep the two organizations aware of each other's activities, share information, provide a bridge between government-industry and government-university cooperative efforts, and speak for the broader interests of those involved in geothermal R\&D.

The committee concluded that an organization such as GRO would serve as an excellent means of coordinating both the relatively small number of academic researchers working on long-term geothermal research and the large number of scientists working in allied flelds. With a long-term commitment of DOE and other federal funding, significant progress could be made in understanding the nature of the advanced geothermal resources and the prospects for long-term economic development of those resources.

\section{CONCLUSIONS AND RECOMMENDATIONS}

\section{Conclusions:}

Given the existing economics of energy and the state of the U.S. geothermal industry, the Geothermal Drilling Organization is judged to be the best approach to short-term, drilling R\&D and should be modifled to address short- to mid-term geothermal development. 
Recommendations:

- The charter of the GDO should be expanded from its current coverage of "geothermal drilling" to "short- to mid-term geothermal development." The GDO's name should be changed to the Geothermal Development Organization and a restructuring implemented.

- A Geothermal Research Organizaiton should be formed, composed of researchers interested in the scientific and technological issues in developing long-term geothermal energy resources: geopressured, hot dry rock, and magma energy. This organization would serve as an excellent means of coordinating the relatively small number of academic researchers working on these long-term resources and the large number of scientists working in allied fields. 


\section{APPENDIX A}

\section{STATEMENT OF TASK}

1. Review the U.S. geothermal goals and the DOE program. Identify the nonprice constraints to geothermal as a future energy source, in particular, environmental, land use, and public utility concerns. 2. Identify and prioritize the major technical, economic, environmental, and institutional issues in developing geothermal energy resources. 3. Review current DOE Geothermal Energy Technology Program efforts to cooperate with Industry, academia, and other parts of the government, in light of the above, and the strategy of greater rellance on and interaction with private companies and university researchers.

4. Plan and conduct a two-day workshop at which industry, government, and university panels of experts will discuss major issue areas and give their views on the role of DOE's Geothermal Energy Technology Program in cooperating with other sectors: academia, Industry, and other parts of the government. The panel members will review current cooperative efforts, suggest opportunities and mechanisms for enhanced cooperation, and foin the committee in a discussion of the benefits and limitations of the various mechanisms over the near and long terms.

5. Compare the issues Identified by the committee with the issues currently addressed by DOE's Geothermal Energy Technology Program, especialiy as they affect the program's cooperative links with universities, Industry, and other parts of the federal government. 6. Develop two scenarios for cooperation with industry, academia, and government. The first scenarlo will take the current geothermal R\&D program and goals, as given, and consider optimal cooperative activities with the other sectors at alternative funding levels. The second scenario will assume a modified program structured around the major issues given priority by the committee and consider optimal cooperation with the other sectors at alternative funding levels. In each case, the committee will identify a range of options that could improve the industry-government-university R\&D infrastructure germane to geothermal energy.

7. Prepare a report of the study.<smiles>O=CC(=O)[AsH3]</smiles> 



\section{APPENDIX B \\ GEOTHERMAL ENERGY WORKSHOP: \\ RED AND COOPERATIVE ARRANGEMENTS \\ Monday, February 9-10, 1987 \\ National Academy of Sciences \\ Joseph Henry Bullding, Room 455 \\ 2100 Pennsylvania Avenue, N.W. \\ Washington, D.C. 20418}

AGENDA

Monday. February 9, 1987
$8: 00$ a.m.
CONTINENTAL BREARFAST
$8: 30$ a.m.
OPENING REMARKS AND INTRODUCTIONS
Dennis F. Miller, Executive Director
Energy Engineering Board
Norman Hackerman, Chairman,
Committee on Geothermal Energy Technology Program
$8: 45$ a.m.
RECOMLENDATIONS FOR DOE'S GEOTHERMAL TECHNOLOGY
PROGRAM: A FIVE-YEAR PERSPECTIVE
Carel Otte, President, Geothermal Division,
Unocal Corporation
$9: 45$ a.m.
DISCUSSION
$10: 10$ a.m.
GEOTHERMAL ENERGY-ENVIRONMENTAL ISSUES
Hamilton Hess, Geothermal Coordinator, Sierra Club
$10: 40$ a.m.
OPEN DISCUSSION
11:00 a.m.
INDUSTRY/UNIVERSITY COOPERATIVE EFFORTS
Alex Schwartzkopf, National Science Foundation
$11: 20 \mathrm{a} \cdot \mathrm{m}$.
COOPERATIVE ARRANGEMENTS: SOME EXAMPLES
Alan Schreisheim, Director, Argonne National
Laboratory
$11: 45$ a.m.
OPEN DISCUSSION
$12: 15$ p.m.
LUNCH
$1: 00$ p.m.
JOINT RESEARCH AND DEVELOPMENT VENTURE: A CASE STUDY Michael Lee McQueen, Assistant Council, Unocal Corporation 


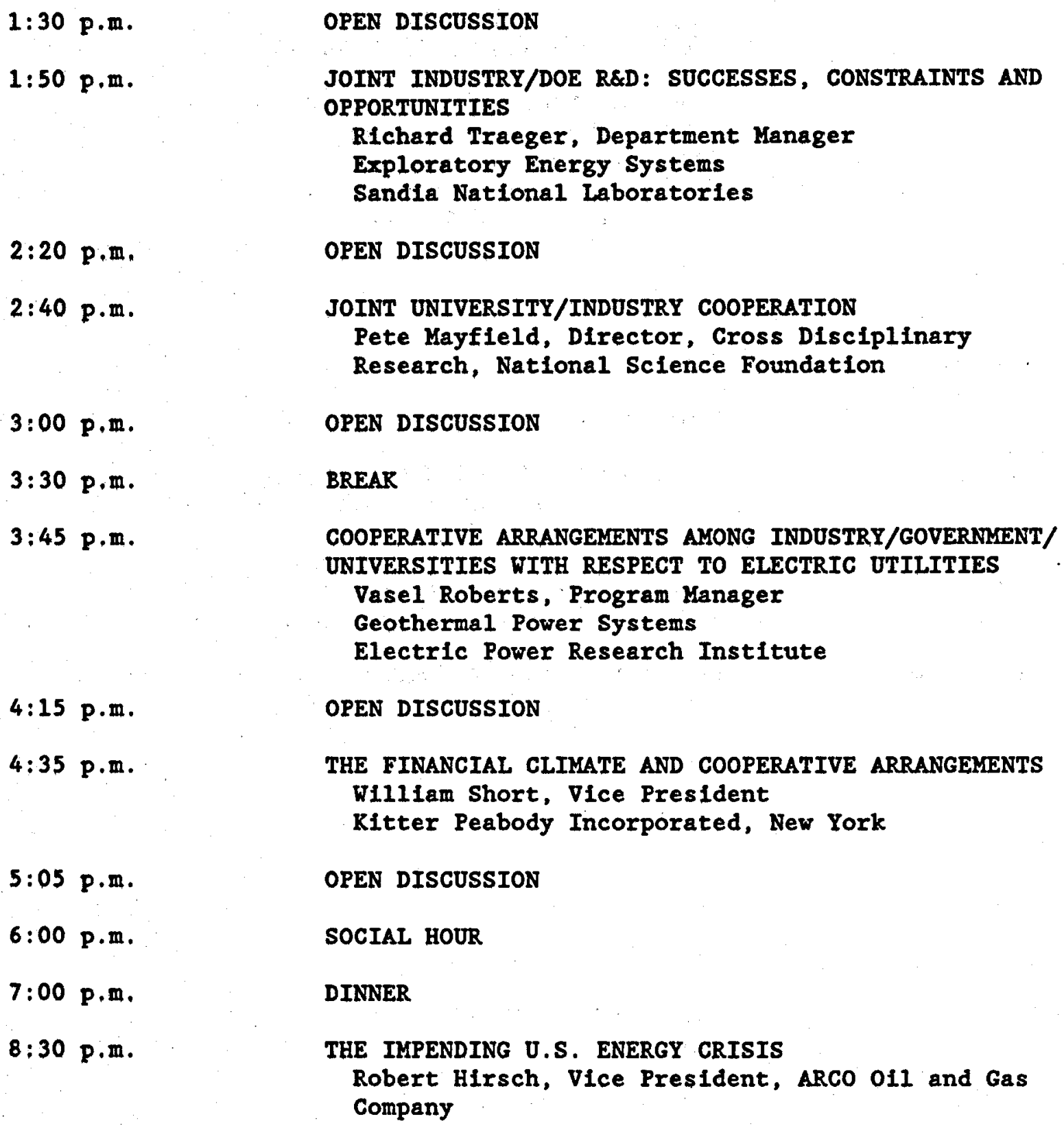

Tuesday, February 10, 1987

8:00 - 11:00 a.m. DISCUSSION BETWEEN COMMITTEE AND SELECTED SPEARERS AND MEMBERS OF ADVISORY GROUP ON COOPERATIVE ARRANGEMENTS 
ATTENDEES

\section{Committee Hembers}

Norman Hackerman, Chairman

The Robert A. Welch Foundation

James B. Combs

Geothermal Resources International, Inc.

Myron H. Dorfman

University of Texas

Wilfred A. Elders

University of California

Stephen J. Gage

Midwest Technology Development Institute

Robert G. Lacy

San Diego Gas \& Electric

Carel Otte

Unocal Corporation

Martin Robbins

Colorado School of Mines

Jefferson W. Tester

Massachusetts Institute of Technology

Eric A. Walker

The Pennsylvania State University

\section{Presenters}

Hamilton Hess

Slerra Club

Robert Hirsch

ARCO 011 and Gas Company

Pete Mayfield

National Sclence Foundation

Michael Lee McQueen

Unocal Corporation 


\section{Carel Otte}

Unocal Corporation

Vasel Roberts

Electric Power Research Institute

Alan Schreisheim

Argonne National Laboratory

Alex Schwartzkopf

National Science Foundation

William Short

Kitter Peabody, Inc.

RIchard Traeger

Sandia National Laboratories

\section{Advisory Group}

Daniel Cublcclotti

Electric Power Research Institute

Lansing Felker

o.s. Department of Commerce

Herbert Fusfeld

Rensselaer Polytechnic Institute

Robert Hirsch

ARCO 011 and Gas Company

Tom Hogan

National Sclence Foundation

Harold Hubbard

Solar Energy Research Institute

Richard Nelson

Columbia University

Tom O'Hare

Brookhaven National Laboratory

Manik Talwanl

Houston Area Research Center 
MEETING OF THE COMMITTEE ON GEOTHERMAL ENERGY TECHNOLOGY PROGRAY

February 10, 1987 (Tuesday)

$$
8: 30 \text { a.m. }
$$

$10: 15$ a.m.

$10: 30$ a.m.

$12: 00$ noon

$1: 00$ p.m.

5:00 p.m.

$8: 30$ a.m.

5:00 p.m.

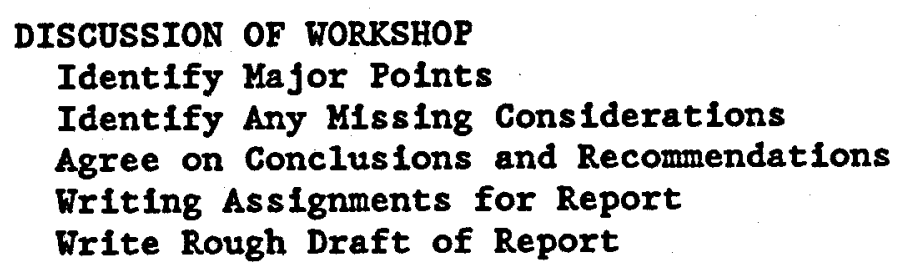

BREAK

CONTINUATION OF MEETING

Writing Sessions

LUNCH

CONTINUATION OF MEETING

ADJOURNMENT

February 11, 1987 (Wednesday)

CONTINUATION OF PREVIOUS DAY

Writing Sessions

Review of Written Sections

Identification of Missing Parts

Writing Assignments and Deadlines for

Completion of Final Report

ADJOURNMENT 

APPENDIX C

CONVERSION TECHNOLOGIES FOR POWER GENERATION

Three basic concepts for conversion technologies are being used to produce electric energy from hydrothermal resources. The many versions of these conversion systems need to be examined for each application. They have reached their present state of evolution with varying levels of federal funding.

DRY STEAM SYSTEM

The dry steam system conversion technology is used at The Geysers. The system is based on conventional power plant steam technology adapted and perfected by private industry for use here. Figure C-1 is a simplified schematlc diagram of a dry steam system.

Dry, slightly superheated steam from the production wells operates a condensing steam turbine that in turn drives a generator. The exhaust steam is condensed in a direct contact condenser, and the condensate is used as makeup to a mechanical draft cooling tower. Cooling tower blowdown is usually reinjected.

Dry steam conversion technology has been considered commerclally available by the geothermal and electric utility industries for many years. This technology is attractive and economically competitive, but dry steam hydrothermal reservoirs are rare.

\section{SINGLE AND DOUBLE ELASH SYSTEMS}

Single and double flash system conversion technology is being used increasingly on high-temperature (above $180^{\circ} \mathrm{C}\left[350^{\circ} \mathrm{F}\right]$ ) water-dominated reservolrs. These systems are based on old (early 20th century) steam plant technology. Equipment and techniques for separating clean steam from geothermal brines and handling the highly saline brines have been the targets of extensive R\&D efforts by both industry and the federal government. 


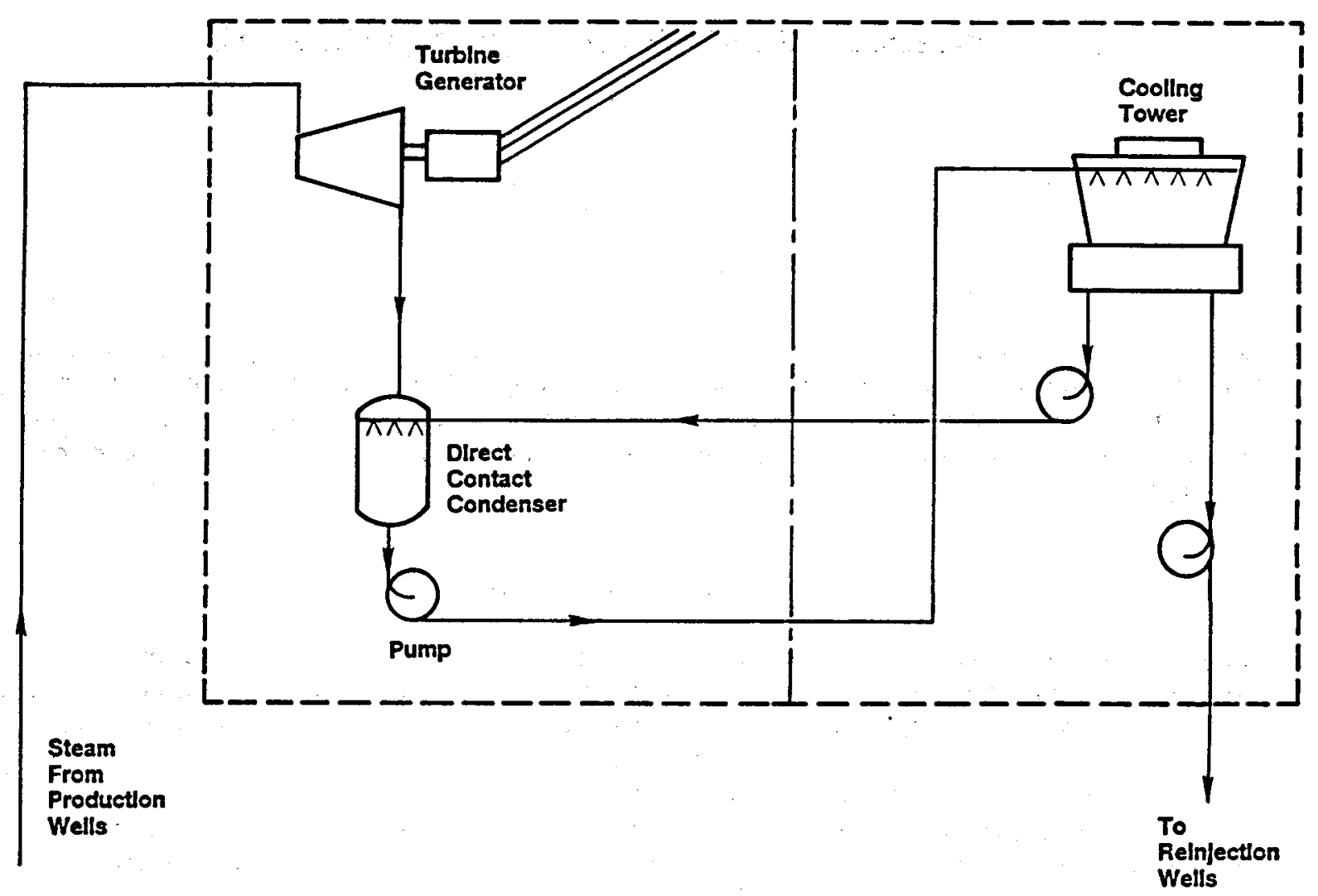

FIGURE C-1 Schematic Diagram of a Dry Sterm System.

SOURCE: Restin et al. (1980). 
In this country, research and development in the use of 1iquiddominated resources for power generation began with experiments in the Imperial Valley of California at the Salton Sea in 1972. These experiments were followed in 1976 by completion of the DOE Geothermal LOOp Experimental Facility, the first cooperative, jointly funded governmentindustry geothermal demonstration facility. Its purpose was to determine the technical and economic feasibility of generating electricity with highly saline brines. The most significant success of this venture was development of the reactor-clarifier brine treatment system, which, with more recent industry modification, permits the use of these brines in several power plants today. A simplifled schematic diagram of a single flash system is presented in Figure C-2. In this system, the production wells are permitted to flow spontaneously, resulting in a two-phase mixture of 1Iquid brine and steam at the surface (this is known as flashing). The mixture is routed to a separator, and the separated scrubbed steam operates a condensing steam turbine, that in turn drives a generator. The separated brine is reinjected. The condensed steam is often used as makeup to a mechanical draft cooling tower. Cooling tower blowdown may be reinjected.

A double flash system involves the flashing of the separated brine a second time to produce additional steam at a lower-pressure. This lowerpressure steam is used to operate a separate steam turbine or is introduced into the high-pressure turbine through a second admission point.

Single and double flash systems are in commerclal service today in the United States. However, their use is limited to high-temperature resources. The high capital cost of these systems, if installed on moderate-temperature resources, makes them uneconomical until the cost of the resource development can be reduced.

\section{BINARY CYCLE SYSTEM}

Binary cycle technology is the preferred alternative for developing 1iquid-dominated reservoirs that are not hot enough for efficient flash steam production but that contain enough heat to evaporate an organic working fluid in the $105^{\circ}$ to $200^{\circ} \mathrm{C}\left(200^{\circ}\right.$ to $\left.400^{\circ} \mathrm{F}\right)$ temperature range. Some small (< $13 \mathrm{MWe}$ ) binary power plants are in commercial service in the United States (see Appendix F). A simplified schematic diagram of a binary cycle system is presented in Figure C-3.

In the binary cycle steam, the hot brine is pumped from the reservoir to avoid flashing and two-phase flow. The brine ylelds its energy in counterflow heat exchangers to a working fluid with a low boiling point. The working fluld may be a fluorocarbon, a hydrocarbon such as isobutane or pentane, or a mixture of similar substances. The working fluld, which is vaporized in the heat exchangers, operates a turbine that in turn drives a generator. The exhaust vapor is condensed in a surface condenser, which is cooled with water from a mechanical-draft cooling water. 


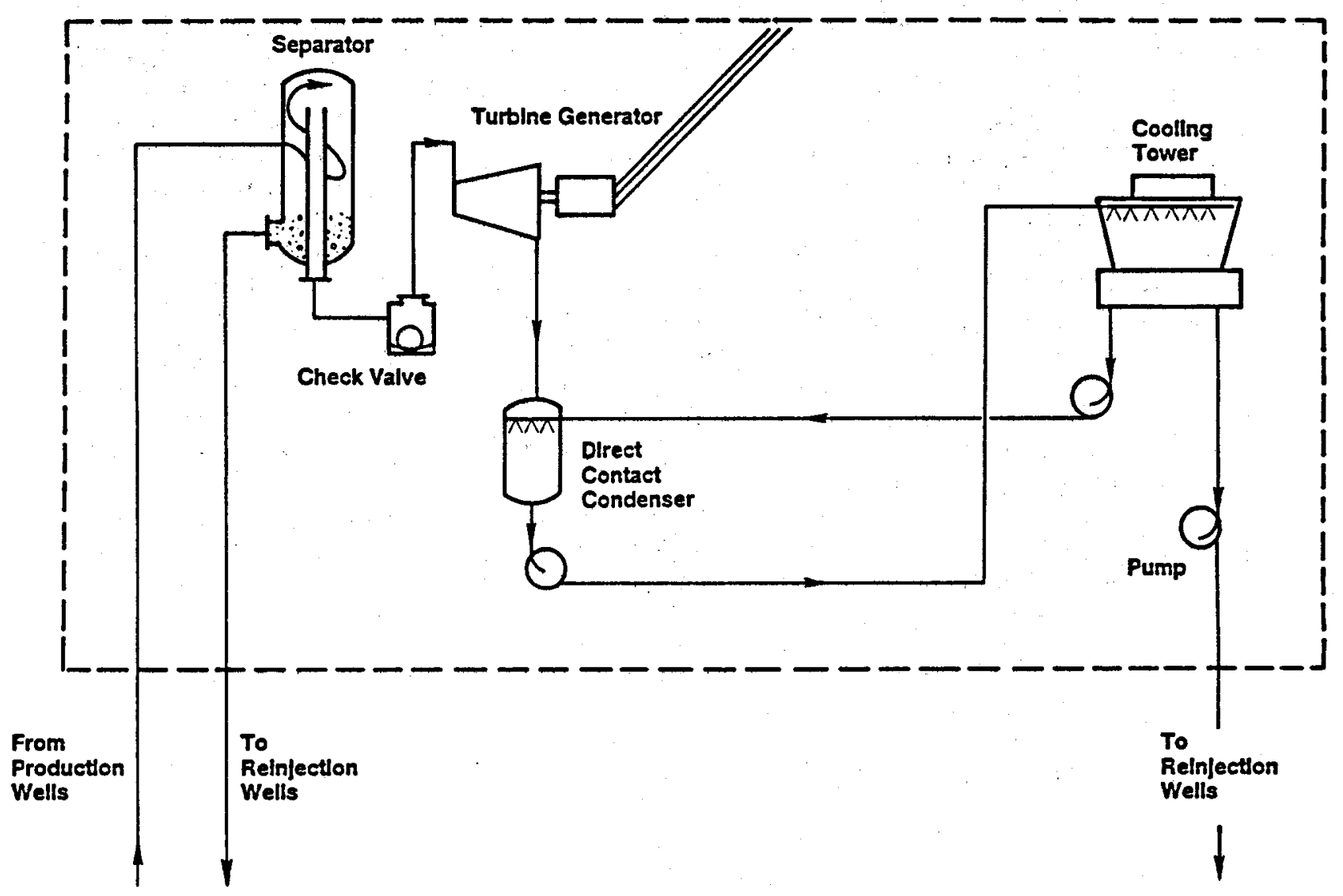

FIGURE C-2 Schematic Diagram of a Single Flash System. 


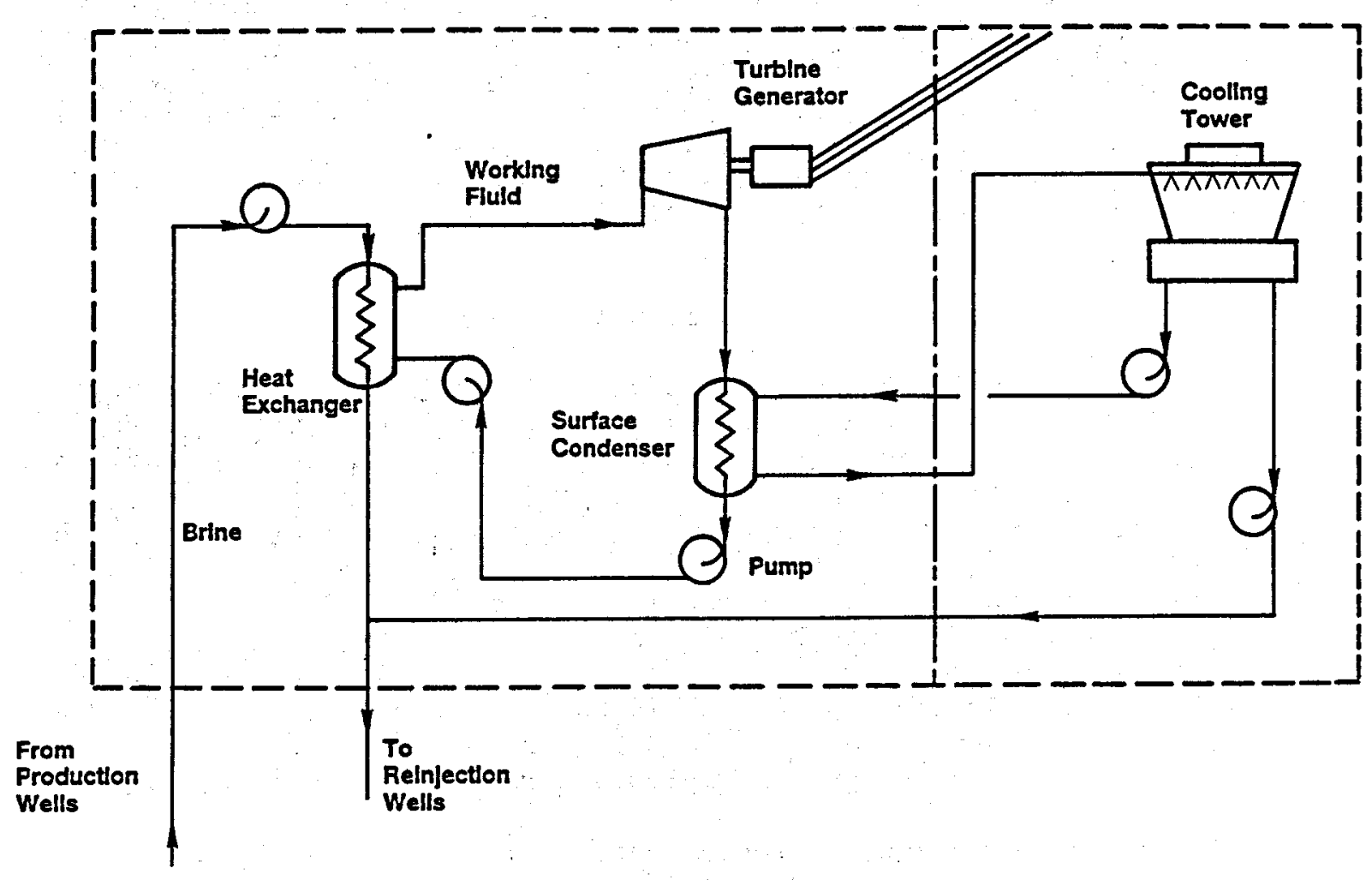

FIGURE C-3 Schematic Dlagram of a Binary Cycle System. SOURCE: Kestin et al. (1980). 
The importance of a commercially viable binary cycle conversion system to the geothermal industry and the nation stems from its broad applicability. Approximately 80 percent of the hydrothermal resources in the United States are moderate-temperature resources that can be developed economically only with this technology. These reservoirs represent 50 percent of the potential electric generation from hydrothermal resources. Fully 40 percent of electric generation from future plants on geopressured reservoirs will probably be produced by binary cycle conversion systems. The balance will be produced by methane engines and pressure reduction systems. Further, all electric generation from hot dry rock reservolrs must be produced by binary cycle conversion systems.

\section{Direct Heat Utilization}

Because of the relatively low temperatures of geothermal flulds (typically $100^{\circ}$ to $300^{\circ} \mathrm{C}$ ), nonelectric direct uses are frequently attractive for geothermal systems. These include industrial process heat applications in which geothermal fluids might be used to generate steam or hot water needed to supply heat to a manufacturing operation. For example, in the paper industry, large quantities of steam are required for pulp digestion and paper drying at temperatures ranging from $150^{\circ}$ to $100^{\circ} \mathrm{C}$. Space heating applications for geothermal heat are widespread, with sultable temperatures of $70^{\circ}$ to $100^{\circ} \mathrm{C}$. Examples in the United States are found at Klamath Falls, Oregon, and Boise, Idaho, and worldwide, in Iceland and the USSR. Even lower geothermal fluid temperatures $\left(<50^{\circ} \mathrm{C}\right)$ can be upgraded by heat pump design. Examples are found:In Auburn, New York, and In France.

One economic advantage to process heat applications is the inherenty large load factors of many industrial processes. Space heating applications are less attractive because of lower load factors. Substantial use of geothermal energy for space heating in the United States will require extensive and costly retrofitting.

Cogeneration is sometimes well-suited to geothermal energy use. It includes electric power combined with process heat systems for large industrial users or the use of geothermal heat for feedwater heating in a fossil-fueled base station power plant.

A substantial fraction of the U.S. annual energy budget of about 80 quads produces heat used at temperatures below $20^{\circ} \mathrm{C}$. Recent estimates indicate that over 25 percent, or about 20 quads per year, could be supplied by geothermal energy. Clearly, the extent to which this contribution occurs will depend in large part on the cost of geothermal heat versus the competition, particularly natural gas and oil. Principal issues affecting direct heat use include the following:

1. Distance between the geothermal resource and end user, which is critical to fluid distribution cost

2. Chemistry of the geothermal fluid, which may lead to corrosion and scaling of heat exchange surfaces

3. Quality of the resource in terms of temperature and depth. 
APPENDIX D

GENERIC DEVELOPMENT NEEDS

UNCERTAINTIES IN LOCATING AND

CHARACTERIZING RESERVOIRS

Characterization of liquid-dominated hydrothermal reservoirs is required to attract financial investment. Current methods of characterization are costly, and better and less costly technologies that embrace geology, geophysics, and geochemistry are needed to locate, delineate, characterlze, and manage hydrothermal reservolrs.

Further technology refinements are required for: locating natural fracture systems and defining other relevant properties of reservoirs, matching the energy conversion process to be used to the reservoir characteristics, and forecasting reserves, including model verification of reservolr capaclty and behavior under production conditions. The use of improved technologies for exploration is especially necessary in the case of "hidden" reservolrs that have no attendant surface manifestations.

\section{HIGH DRILLING COSTS}

High temperatures, hard rocks, and corrosive flulds ralse geothermal drilling costs up to four times those for oll and gas wells at similar depths. These initial costs limit geothermal energy use for electric power generation and for many direct uses.

One of the more costly problems in geothermal drilling involves the loss of drilling fluid into fractured or highly permeable zones, thus interrupting circilation in the drilling fluld system. This interruption can account for up to 30 percent of the well cost. Other problems contributing to costs are maintaining borehole stability during drilling, completion, and production; the high cost of high-temperature drilling flulds; and the less-than-optimal speed and effectiveness of materials and equipment in penetrating hard rock. 


\section{CORROSION PREVENTION AND MATERIALS DURABILITY}

Many geothermal waters leached from reservolr rocks contain dissolved solids and gases that corrode materials. Materials fall relatively quickly unless preventive measures are taken and corrosion-resistant materials are used.

Control of corrosion is better understood today, but much remains to be learned about the complex chemistry of flulds and their behavior under variable operating conditions. Research on corrosion prevention techniques is needed, especlally in the following areas:

- Chemical corrosion inhibitors

- Cathodic and anodic protection

- Chemistry and kinetics

- Sampling and analysis.

Alternative cost-effective materials are needed to limit corrosion, enhance system performance, and reduce maintenance requirements. Research is needed on high-temperature elastomer formulations for dynamic seals and on fabrication and field-testing of elastomer-ilned well casings. High thermal conductivity nonmetalilc composite materials for heat exchanger tubing and metallic cladding for well casings are also needed.

LACK OF EFFICIENT COMPONENTS: DOWNHOLE PUNPS AND INSTRUMENTATION

Downhole pumping is an often useful or necessary adjunct to geothermal power plant development given moderate-temperature resources. It can increase flow, reduce solids precipitation, or maintain the brine in a 1iquid state for binary application. But submersible downhole electric pumps are not sufficiently rellable for economical use.

Historically, the major limitation of this technology has been thermal degradation of the motor and power cable by high temperatures and intrusion of the brine. Recent research and development have resulted in low-horsepower units that can survive and operate for a year in $80^{\circ} \mathrm{C}\left(175^{\circ} \mathrm{F}\right)$ brine, a performance that needs to be improved and extended to larger and hotter systems. One option is development of new metal-sheathed power cable, although efforts to upgrade pumps adapted from oll production may have already reached their limits. A wholly new design and approach may be needed. Deep well operation requires logging, that is, the measuring, recording, and evaluation of downhole conditions, especially in the geothermal environment. 
Considerable work remains to improve or develop high-temperature downhole instrumentation. Specific areas of concern are discussed in Chapter 2 in the section on hydrothermal resources, including fracture detection and mapping devices, electric cables, fluid samplers, and logging tools.

\section{INJECTION TECHNOLOGY FOR ECONOMIC DISPOSAL OF SPENT BRINES}

Successful exploitation of a reservoir requires technology for disposing of large quantities of spent brines. Surface disposal is generally feasible only when the geothermal fluid is sufficlently pure to avoid adverse environmental consequences but it rarely is. This is rare. Otherwise, the fluld must be disposed of by subsurface injection.

If the spent fluid is not injected into the producing reservoir, the system may be depleted, resulting in insufficlent fluid flow for operation or subsidence or both. Though injection recharges the system, short-circulting of the fluid to the production zone before it reaches temperatures suitable for energy conversion must be avoided.

Fluid injection may result in precipitation of scale from the brine, blocking the flow paths and requiring either expensive workover or drilling a new well. Because dissolved solids from a given well vary, effective continuous monitoring instrumentation is needed, as are models to predict the degree of scaling under varlable fluid conditions.

The technologies needed to ensure correct siting of injection wells to delineate flow and heat transfer mechanisms require $R \& D$ to improve geosclence techniques. In addition, further $R \& D$ is needed to improve the appication of tracer methods for predicting and monitoring fluid migration.

\section{CONVERSION TECHNOLOGY}

Recent binary plant experience indicates that pump designers and fabricators have problems predicting the dynamic performance of working fluid pumps. Pumps are now based on suppliers' extensive experience in designing and fabricating water pumps. This experience cannot always be directly applied to pumps intended for service with other flulds. For example, liquid hydrocarbons are much more compressible than water. The lack of applicable pump design tools results in unexpected vibration problems and poor pump rellabllity.

A DOE target is to improve binary cycle efficiency by as much as one third over current advanced cycle technology such as two phase turbine expansion and a combined direct contact heat exchanger and crystallizer. Though direct contact exchangers do not appear to enjoy economic advantages over surface types for some applications, they may be the best hope under conditions of high scaling, an application that would be enhanced with the addition of a crystallizer. For binary technology to be successfully applied at lower temperatures $\left(<150^{\circ} \mathrm{C}\right.$ $\left.\left[302^{\circ} \mathrm{F}\right]\right)$, even more advanced concepts, such as an ammonia cycle, need to be investigated. 
Thus, work is required on the following:

- Improved performance cycles

1. Two-phase expansion

2. Direct contact heat exchanger and crystallizer

- Component improvement

1. Hydrocarbon pump dynamics

2. Brine production pumps

3. Control systems. 


\section{APPENDIX E}

\section{BACRGROUND INFORMATION}

\section{HISTORICAL PERSPECTIVE ON THE GEOTHERMAL PROGRAM}

Following a preliminary assessment of $0 . S$. geothermal resources by the U.S. Geological Survey (USGS) and enactment of the Geothermal steam Act in 1970, a 1971 leg1slative mandate established a geothermal program in the Atomic Energy Commission (AEC). The AEC program emphasized geothermal technology, and attempted to relate to industrial applications. About the same time, the National Science Foundation (NSF) considered geothermal energy in its Research Applied to National Needs project and thereafter became the lead agency for geothermal energy activities. The USGS, AEC, and NSF prepared the first coordinated federal geothermal energy plan in 1973.

In 1974, the Geothermal Energy Research, Development, and Demonstration Act created a national commitment to "dedicate the necessary financial resources and enlist the cooperation of the private and public sectors in developing geothermal resources. . ." The Energy Research and Development Administration (ERDA), created shortly thereafter, was given responsibility for implementing the R\&D program. Implementation subsequently passed to the Department of Energy (DOE) when it was created in 1977.

A formal commercialization program was then infliated to promote early use of hydrothermal resources for both power generation and direct use. The commerclalization program functioned for a time as a separate entity from the technology development division. From 1977 through 1981 , the budget for the commercialization efforts was by far the largest element of the total geothermal energy budget. This budget embraced expenditures for the Baca, New Mexico, and Heber, California, cooperative power plant facilities; a program for direct use, resource assessment efforts by Industry and some states; and studies on leasing, environmental, and other problems. Th1s budget element remalned high through 1983 , reflecting the final federal outlays committed for the Heber plant. In 1981, however, a policy decision was made to rely on the market and on incentives of the National Energy Act of 1978 for geothermal energy commerclalization. Emphasis shifted back to research and technology development (R\&D), where it remains today. The budget history of the geothermal program from fiscal year 1976, when the Department of Energy (DOE) inherited it from ERDA, is shown in Table 2-1. A significant decline from nearly $\$ 158$ million in 1979 to about $\$ 21$ million in fiscal year 1987 occurred. 
PRIVATE AND PUBLIC RESEARCH

AND DEVELOPMENT EFFORTS

U.S. Industry has been conducting geothermal energy R\&D since its early exploration in the 1950s, almost entirely for hydrothermal resources. It also cooperates with DOE, as envisioned by the Geothermal Research, Development, and Demonstration Act, in cosponsoring R\&D projects with the federal government. Other parts of the public sector, e.g., the U.S. Geological Survey (USGS), Bureau of Land Management, Forest Service, and state agencies, also participates in the DOE program.

As indicated above, industry exploration at The Geysers in California and at hot water fields in California and Nevada in the 1950s and 1960s predates the interest in the resource. It was during the 1970 s that the government joined with industry during the 1970 s to bulld a data base on promising hot water reservolrs and confirm the resource potential at selected sites through a government-industry cost-shared program.

Exploration has remained the exclusive purview of industry since then. The DOE contribution here and to related $R \& D$ areas is in continuing research to improve the technology base, enabling industry to develop advanced equipment and techniques for exploration, reservoir characterization, and reservoir engineering and management.

Industry has developed and perfected dry steam technologies used at The Geysers. For example, Industry spent years and considerable funds developing cost-effective hydrogen sulfide abatement technologies. The govermment participated by developing and testing four alternative abatement methods.

R\&D use of liquid-dominated resources for power generation in the Onited States date back to the experiments by San Diego Gas and Electric and Southern California Edison at the Salton Sea in California from 1972 through 1975. These experiments were followed in 1976 by the completion of the DOE Geothermal Loop Experimental Facility in the area, the first cooperative, jointly funded government-industry geothermal demonstration facility. Its purpose was to determine the technical and economic feasibility of generating electricity with highly saline brines. The most significant success of this venture was development of the reactorclarifier brine treatment system, which, with more recent industry modifications, permits the use of these brines in several power plants. today, opening development of a large geothermal resource at that site.

Industry R\&D projects then included small geothermal power plants to demonstrate both the flash steam and binary technologies. Magma Power Company established a 10-MWe binary plant for using the relatively benign but moderate-temperature fluids produced at the East Mesa field in the Imperial Valley of California, Unocal and Southern California Edison were the principal participants in 10-MWe flash plants at the Brawley Reservoir 
in Imperial Valley, where the brine salinity is only slightly less hostile than that at the Salton Sea, and subsequently at the Salton Sea geothermal field itself with salinities of $300,000 \mathrm{ppm}$ ( 30 percent by weight).

Over the years, industry has spent at least $\$ 100$ million to perfect the use of Imperial Valley saline geothermal brines. DOE and industry undertook to demonstrate commercial-scale power plants at Baca, New Mexico (flash), and Heber, California (binary). Production at Baca reservoir could not support the project, and although it was canceled, many valuable lessons were learned for future application. The 45-MWe (net) binary plant at Heber, designed as a demonstration plant to yield data for binary technology in general, is now in operation; it will provide data on the economics and operational viability of large-scale binary technology applicable to a wide range of moderate-temperature, low-salinity reservolrs. The data will also be applicable to small wellhead power plants. DOE has supported research on advanced binary technology, with emphasis on the application of direct contact heat exchangers.

DOE also supported development of technologies for direct use of energy from low-temperature geothermal fluids rather than its conversion to electricity. Under the Project Opportunity Notice Program of the late 1970 s, DOE cost-shared 23 direct use projects with industry, municipalities, and institutions to demonstrate the technical and economic feasibility of a variety of applications. The program produced five successful and currently expanding district heating systems, six institutional space heating projects, a large commercial greenhouse, a 50-acre aquaculture project, and a cascade application combining agriculture and aquaculture.

Geothermal electric power production and most direct use applications require the production and disposal of large quantities of geothermal fluids. DOE R\&D is attempting to ensure the technical efficiency, environmental safety, and cost effectiveness of reinjecting these fluids Into the subsurface.

DOE and industry are conducting R\&D to increase the fundamental knowledge of hydrothermal reservoirs through cost-shared drilling in the Cascades Range of the Pacific Northwest, which is believed to contain a large resource that is difficult to discover because of the effects of high levels of rainfall and snow on shallow subsurface temperature gradients. In addition, drilling for scientific data has been undertaken in the Salton Sea area in California, under the auspices of the Interagency Accord on Continental Scientific Drilling, to investigate a major hydrothermal system at greater depths than has been possible before. DOE, USGS, and NSF are signatory to the accord.

DOE is also conducting long-term R\&D to develop technologies for extracting and utilizing geopressured geothermal brines and the heat of hot dry rock, and to determine the engineering feasibility of extracting energy directly from relatively shallow magma bodies. The fundamental data developed will allow industry to evaluate the commercial potential of these more difficult resources.

Privately funded industry R\&D is highly fragmented due to the dissimilar elements in the industry. Given present energy markets and the limited private funding avallable for energy R\&D, field development 
efforts are limited, to a large extent to site-specific problem solving. Power plant operators, whether utilities or third party, are essentially at the same level of R\&D. A Unocal/Southern California Edison partnership effected the first technology transfer from one plant to another in incorporating many of the technological breakthroughs achleved at the Brawley plant to the Salton Sea plant, permitting more efficient operation at the outset.

The Electric Power Research Institute has an active small geothermal R\&D program. Similarly, the Gas Research Institute has a program on studying methane in geopressured brines. The geothermal R\&D activities by EPRI include analyses of power systems, chemical analyses of the resource, and cooperation in experiments to generate electrical power.

The R\&D conducted by equipment manufacturers and service-oriented companies is as diverse as the nature of the firms themselves, and developments in materials, components, and hardware systems are often supported wholly or in part by DOE. One notable exception is Schlumberger, whose entire company operation is based on its own R\&D in well-logging technology.

The geothermal energy research activities of USGS are closely coordinated with those of DOE. When the USGS program directly supports specific DOE objectives, DOE provides funding to increase the timeliness of needed Information. Most recently USGS is supporting the reservolr technology element of the DOE R\&D program.

USGS, the Bureau of Land Management, and the Forest Service cooperated with DOE in a 1978 study on the effects of various provisions of Department of the Interfor regulations (pursuant to the Geothermal Steam Act) on U.S. geothermal development. Improvements have been made in leasing and environmental study procedures in many areas, although some problems remain, as discussed in Chapter 2.

The State-Coupled Resource Assessment Program undertook to compile reglonal geothermal data on low- to moderate-temperature geothermal systems, to refine exploration target models, and to delineate optimal geothermal environments. Technical assistance to states for reservoir assessment is continuing on a limited and selected scale.

The results of federal, private, and public geothermal R\&D are manifested in 16 operational hot water geoelectric plants, with a total capacity exceeding $215 \mathrm{MWe}$, over $60 \mathrm{MWe}$ under construction in four plants, and more than 20 plants being planned. As of 1982, the hot water "Industry" consisted of $33 \mathrm{MWe}$ in four small demonstration plants. The success of private sector R\&D is impressively represented by The Geysers geothermal complex, the largest in the world. 


\section{APPENDIX F \\ INVENTORY OF GEOTHERMAL POWER PLANTS}

Tables F-1 through F-4 provide an inventory of geothermal power plants in the United States and the world. 
TABLE F-1 Geothermal Power Plants at The Geysers, California

\begin{tabular}{|c|c|c|c|}
\hline 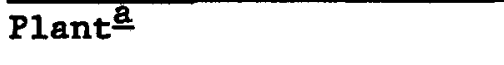 & Year & MWe & Status \\
\hline \multicolumn{4}{|l|}{ PG \& E Geysers } \\
\hline Unit 1 & 1960 & 11 & Operational \\
\hline Unit 2 & 1963 & 13 & Operational \\
\hline Unit 3 & 1967 & 27 & Operational \\
\hline Unit 4 & 1968 & 27 & Operational \\
\hline Unit 5-6 & 1971 & $2 \times 53$ & Operational \\
\hline Unit 7-8 & 1972 & $2 \times 53$ & Operational \\
\hline Unit $9-10$ & 1973 & $2 \times 53$ & Operational \\
\hline Unit 11 & 1975 & 106 & Operational \\
\hline Unit 12 & 1979 & 106 & Operational \\
\hline Unit 13 & 1980 & 133 & Operational \\
\hline Unit 14 & 1980 & 109 & Operational \\
\hline Unit 15 & 1979 & 59 & Operational \\
\hline Unit 16 & 1985 & 113 & Operational \\
\hline Unit 17 & 1982 & 113 & Operational \\
\hline Unit 18 & 1983 & 113 & Operational \\
\hline Unit 19 & n.a. & 55 & Preliminary planning \\
\hline Unit 20 & 1985 & 113 & Operational \\
\hline Unit 21 & 1988 & 140 & Advanced Planning \\
\hline Unit 22 & n.a. & 140 & Preliminary planning \\
\hline Unit 23 & n.a. & 114 & Preliminary planning \\
\hline Unit 24 & n.a. & 114 & Preliminary planning \\
\hline Thermal-4 ("Wild Well") & n.a. & 2 & Preliminary planning \\
\hline NCPA 2 & 1983 & $2 \times 55$ & Operational \\
\hline SMUDGEO NO. 1 & 1983 & 72 & Operational \\
\hline Bottle Rock & 1985 & 55 & Operational \\
\hline OXY 1 & 1984 & 80 & Operational \\
\hline \multicolumn{4}{|l|}{ NCPA 3: } \\
\hline Unit 3 & 1985 & 55 & Operational \\
\hline Unit 4 & 1986 & 55 & Operational \\
\hline Modesto GEO & n.a. & 110 & Preliminary planning \\
\hline South Geysers & -- & 55 & Cancelled \\
\hline SMUDGEO NO. 2 & 1987 & 55 & Preliminary planning \\
\hline CCPA No. 1: & & & \\
\hline Coldwater Creek & 1988 & $2 \times 65$ & Under construction \\
\hline Total & & $\begin{array}{l}1,788 \\
2,648\end{array}$ & $\begin{array}{l}\text { Operational } \\
\text { Operational, under } \\
\text { construction, or } \\
\text { planned }\end{array}$ \\
\hline
\end{tabular}

a All units are of the dry steam type.

SOURCE: DIPIPPO (1986). 
TABLE F-2 Geothermal Power Plants in the Imperial Valley, California

\begin{tabular}{|c|c|c|c|c|}
\hline$\overline{\text { Plant }}$ & Year & Type & MWe & Status \\
\hline East Mesa & & & & \\
\hline $\begin{array}{l}\text { B.C. McCabe No. } 1 \text { (Magma) } \\
\text { East Mesa No. } 2 \text { (GEO }{ }^{-} \text {) } \\
\text { East Mesa No. } 3 \text { (GEO }{ }^{\mathrm{a}} \text { ) } \\
\text { ORMESA I (Ormat) } \\
\text { ORMESA II (Ormat) }\end{array}$ & $\begin{array}{l}1979 \\
1988 \\
1989 \\
1987 \\
1988\end{array}$ & $\begin{array}{l}\text { Binary } \\
\text { 2-flash } \\
2-\text { flash } \\
\text { Binary } \\
\text { Binary }\end{array}$ & $\begin{array}{r}12.5 \\
37.0 \\
37.0 \\
26 \times 0.77 \\
25 \times 0.77\end{array}$ & $\begin{array}{l}\text { Operational } \\
\text { Under construction } \\
\text { Under construction } \\
\text { Operational } \\
\text { Under construction }\end{array}$ \\
\hline
\end{tabular}

Salton Sea

$\begin{array}{lllll}\text { Salton Sea (Unocal/SCE) } & 1982 & \text { 1-flash } & 10.0 & \text { Operational } \\ \text { Salton Sea 3 (Unocal) } & 1988 & 2 \text {-flash } & 47.5 & \text { Under construction } \\ \text { Vulcan I (Magma/BNG) } & 1985 & 2-f l a s h & 39.6 & \text { Operational } \\ \text { Vulcan II (Magma/SCE) } & 1988 & 2-\text { flash } & 39.9 & \text { Under construction } \\ \text { Vulcan III (Magma/SCE) } & 1988 & 2 \text {-flash } & 39.9 & \text { Under construction } \\ \text { Vulcan IV (Magma/SCE) } & 1989 & 2-f l a s h & 39.9 & \text { Under construction }\end{array}$

Heber

$\begin{array}{lrlrl}\text { Binary demonstration plant } 1985 & \text { Binary } & 45.0 & \text { Operational } \\ \text { Flash plant (HGC) } & 1985 & \text { 2-flash } & 47.0 & \text { Operational }\end{array}$

North Brawley

Brawley (Unocal/SCE) 1980 1-flash 10.0 Decommissioned

Total

174.1 Operational

394.7 Operational or under construction

434.6 Operational, under construction, or planned

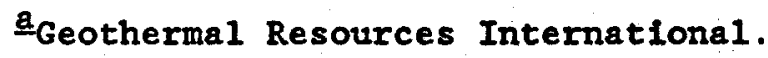

SOURCE: DIPIPPO (1986). 
TABLE F-3 Geothermal Power Plants in the United States (excluding The Geysers and the Imperial Valley)

\begin{tabular}{|c|c|c|c|c|}
\hline State/Plant & Year & Type & MWe & Status \\
\hline \multicolumn{5}{|l|}{ California } \\
\hline \multicolumn{5}{|l|}{ Coso } \\
\hline Unit 1 (Cal. Energy) & 1987 & 1 -flash & 25.0 & Under construction \\
\hline Units $2-3$ & n.a. & 1 -flash & $2 \times 25.0$ & Advanced planning \\
\hline \multicolumn{5}{|l|}{-Mammoth } \\
\hline Mammoth-Pacific & 1984 & BInary & $2 \times 3.5$ & Operational \\
\hline \multicolumn{5}{|l|}{ Chance Ranch } \\
\hline \multirow{3}{*}{$\begin{array}{l}\text { (Wood \& Associates) } \\
\text { Honey Lake }\end{array}$} & 1987 & Binary & $12 \times 0.833$ & Advanced planning \\
\hline & \multirow{2}{*}{\multicolumn{3}{|c|}{ wood-geothermal }} & Under construction \\
\hline & & & & \\
\hline \multicolumn{5}{|l|}{ Wendell Hot Springs } \\
\hline Wineagle Project & 1985 & Binary & $2 \times 0.30$ & Operational \\
\hline \multicolumn{5}{|l|}{ Hawail } \\
\hline Puna No: 1 & 1982 & 1-flash & 3.0 & Operational \\
\hline \multicolumn{5}{|l|}{ Idaho } \\
\hline Raft River & 1982 & Binary & 5.0 & Decommissioned \\
\hline \multicolumn{5}{|l|}{ Nevada } \\
\hline Wabuska Hot Springs & 1984 & Binary & 0.6 & Operational \\
\hline Beowawe & 1985 & 2-flash & 17.0 & Operational \\
\hline \multicolumn{5}{|l|}{ Brady Hot Springs } \\
\hline Phase 1 & 1987 & Binary & 2.8 & Under construction \\
\hline Phase 2 & 1987 & Binary & 5.5 & Under construction \\
\hline Steamboat Springs & 1986 & Binary & $7 \times 0.7 .7$ & Operational \\
\hline Fish Lake & 1986 & Binary & 15.0 & Planned \\
\hline Big Smokey Valley & 1986 & Flash (?) & 10.0 & Planned \\
\hline Desert Peak & 1985 & $\begin{array}{c}\text { Total flow/ } \\
2 \text {-flash }\end{array}$ & 9.0 & Operational \\
\hline Spring Creek & 1987 & $2-f l a s h$ & 20.0 & Planned \\
\hline Dixie Central & 1987 & Flash & 20.0 & Planned \\
\hline \multicolumn{5}{|l|}{ Oregon } \\
\hline \multicolumn{5}{|l|}{ Hammers $1 y$ Canyon } \\
\hline Unit $1-3$ & 1983 & Binary & $3 \times 0.30$ & Operational \\
\hline Unit $4-6$ & 1984 & Binary & $3 \times 0.37$ & Operational \\
\hline \multirow{2}{*}{\multicolumn{5}{|c|}{$\begin{array}{l}\text { Utah } \\
\text { Milford }\end{array}$}} \\
\hline & & & & \\
\hline Blundell Unit 1 & 1984 & 1 -flash & 20.0 & Operational \\
\hline Wellhead No. 1 & n.a. & Total flow & 14.5 & Advanced planning \\
\hline \multicolumn{5}{|l|}{ Cove Fort-Sulphurdale } \\
\hline Phase 1 & 1985 & Binary & $4 \times 0.675$ & Operational \\
\hline Phase 2 & 1986 & Binary & $2 \times 1.0$ & Advanced planning \\
\hline Phase 2 & n.a. & Dry steam & 2.3 & Advanced planning \\
\hline Total & & & 67.31 & Operational $\underline{a}$ \\
\hline & & & 120.61 & Operational or \\
\hline & & & 264.40 & $\begin{array}{l}\text { under constructior } \\
\text { Operational, under } \\
\text { construction, or }\end{array}$ \\
\hline
\end{tabular}


$85 / 86$

TABLE F-4 Geothermal Power Plants on Line Worldwide as of 1986.

\begin{tabular}{|c|c|c|c|c|c|c|c|c|c|c|}
\hline \multirow[b]{3}{*}{ Country } & \multicolumn{8}{|c|}{ Type of Power Plant } & & \\
\hline & \multicolumn{2}{|c|}{ Dry Steam } & \multicolumn{2}{|c|}{ 1-Flash } & \multicolumn{2}{|c|}{ 2-Flash } & \multicolumn{2}{|c|}{ Binary } & \multicolumn{2}{|c|}{ Totals } \\
\hline & NPU旦 & MWe & NPU & MWe & NPU & MW & NPD & MWe & NPU & MWe \\
\hline United States & 26 & 1788 & 3 & 33 & 4 & 109.5 & 24 & 75.81 & 57 & 2006.31 \\
\hline PhIIIppines & 0 & 0 & 23 & 894 & 0 & 0 & 0 & 0 & 23 & 894.0 \\
\hline Mexico & 2 & 10 & 7 & 165 & 5 & 470.0 & 0 & 0 & 14 & 645.0 \\
\hline Italy & 41 & 499.7 & 1 & 4.5 & 0 & 0 & 0 & 0 & 42 & 504.2 \\
\hline Japan & 1 & 22 & 6 & 88.1 & 2 & 105 & 0 & 0 & 9 & 215.1 \\
\hline New Zealand & 0 & 0 & 1 & 10 & 9 & 157.2 & 0 & 0 & 10 & 167.2 \\
\hline E1 Salvador & 0 & 0 & 2 & 60 & 1 & 35 & 0 & 0 & 3 & 95.0 \\
\hline Renya & 0 & 0 & 3 & 45 & 0 & 0 & 0 & 0 & 3 & 45.0 \\
\hline Iceland & 0 & 0 & 4 & 11 & 1 & 28 & 0 & 0 & 5 & 39.0 \\
\hline Nicaragua & 0 & 0 & 1 & 35 & 0 & 0 & 0 & 0 & 1 & 35.0 \\
\hline Indones Ia & 2 & 30.25 & 1 & 2 & 0 & 0 & 0 & 0 & 3 & 32.25 \\
\hline Turkey & 0 & 0 & 1 & 20.6 & 0 & 0 & 0 & 0 & 1 & 20.6 \\
\hline China & 0 & 0 & 6 & 4.866 & 3 & 9 & 6 & 0.7 & 15 & 14.586 \\
\hline Soviet Union & 0 & 0 & 1 & 11 & 0 & 0 & 0 & 0 & 1 & 11.0 \\
\hline France & & & & & & & & & & \\
\hline (Guadeloupe) & 0 & 0 & 1 & 0 & 1 & 4.2 & 0 & 0 & 1 & 4.2 \\
\hline Portugal & & & & & & & & & & \\
\hline (Azores) & 0 & 0 & 0 & 3 & 0 & 0 & 0 & 0 & 1 & 3.0 \\
\hline Greece & 0 & 0 & 1 & 2 & 0 & 0 & 0 & 0 & 1 & 2.0 \\
\hline Total & 72 & 2349.95 & 62 & 1389.086 & 26 & 917.9 & 30 & 76.51 & 190 & 4733.446 \\
\hline
\end{tabular}

$\underline{a}_{\text {Number }}$ of power units.

SOURCE: DIPIPPO (1986). 



\section{APPENDIX G \\ RENEWABLE ENERGY PROGRAM REVIEW}

OCTOBER 15-16, 1986

TUESDAY, OCTOBER 14, 1986

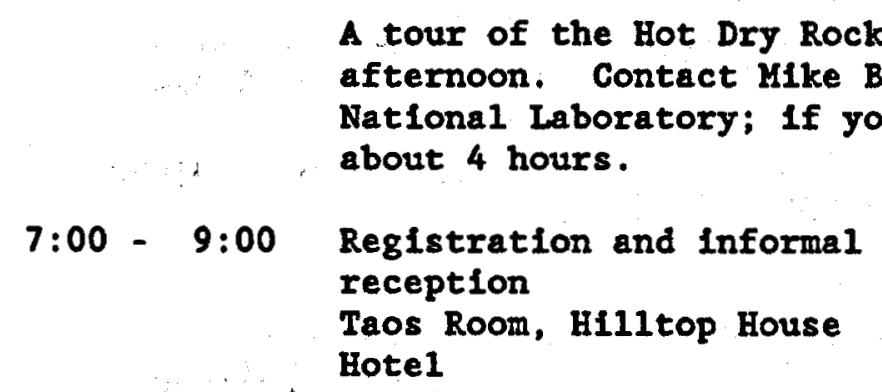

WEDNESDAY, OCTOBER 15, 1986
7:30 - 7:45 Meeting participants meet at Hilltop House and are escorted by bus to TA-53, Bullding 1
$7: 45$ - 8:15 Registration
$8: 15-8: 20$ Welcome
$8: 20$ - $8: 40$ Opening Remarks

Michael E. Berger Phyllis J. Martell

Phyl11s J. Martell

Director S.S. Hecker

Assistant Secretary

Donna Fitzpatrick/

Dr. Thomas O'Hare/

Dr. Robert San Martin

$$
\begin{aligned}
& \text { 8:40 - 8:45 Heeting Format Explanation } \\
& 8: 45 \text { - 9:15 Blofuels Overview } \\
& 9: 15-9: 45 \text { Geothermal Overview } \\
& 9: 45 \text { - } 9: 55 \quad \text { Break } \\
& \text { 9:55 - 11:30 Blofuels and Municipal Waste } \\
& \text { Program }
\end{aligned}
$$

$11: 30-11: 40 \quad$ Break

11:40-1:15 Geothermal Technology Program

Technical Host: Michael E. Berger

\author{
Donald Walter \\ John Kock
}


1:15 - 1:45 Travel to Otowi Bullding and Study Center

$1: 45$

$1: 45-6: 00$

Working lunch

(by invitation only)

Group Discussion Sessions
(Includes Working Lunch)

Biofuels: Growth Technologies, Sideroom A, Otowi Building

Blofuels: Conversion

Technologies, Sideroom B, otowi Bullding

Geothermal: Hydrothermal

Resources, Sideroom C,

Otow1 Bullding

Geothermal: Advanced Resources, Study Center, Room 222

6:00-6:15 Break and walk to University House

6:15 - 7:15 Reception (by invitation only)

$7: 15$ - 7:30 Walk to Otowi Building, Main Dining Room

$7: 30-8: 30$ Dinner (by invitation only)

8:30 - 8:45 Meeting participants returned to Hilltop House

THURSDAY, OCTOBER 16, 1986

8:15 - 8:30 Keeting participants meet at Hilltop House and are escorted to Otowi Building and Study Center
Phyllis J. Martell

Phyllis J. Martell

Wayne H. Smith,

Panel Chairman

To be determined

Carel Otte,

Panel Chalrman

Samue1 Fleming, Panel Chairman

Phyllis J. Martell

Phyllis J. Martell

Phyl11s J. Martell

Phyl11s J. Marte11 


\begin{tabular}{|c|c|c|c|}
\hline $8: 30$ & $-12: 00$ & $\begin{array}{l}\text { Discussion Session (continued) } \\
\text { Prepare findings and chairpersons' } \\
\text { summaries }\end{array}$ & \\
\hline & & $\begin{array}{l}\text { Blofuels: Growth Technologies, } \\
\text { siderroom A, Otowi Building }\end{array}$ & $\begin{array}{l}\text { Wayne H. Smith, } \\
\text { Panel Chairman }\end{array}$ \\
\hline & & Study Center, Room 222 & $\begin{array}{l}\text { Samuel Fleming, } \\
\text { Panel Chalrman }\end{array}$ \\
\hline $12: 00$ & $-12: 05$ & $\begin{array}{l}\text { Walk to Otowi Bullding, Main } \\
\text { Dining Room }\end{array}$ & Phyllis J. Martell \\
\hline $12: 05$ & $-12: 45$ & Lunch, Main Dining Room & \\
\hline $12: 45$ & $-1: 00$ & $\begin{array}{l}\text { Travel to TA-53, Building } 1 \text {, } \\
\text { Auditorium }\end{array}$ & Phyilis J. Martell \\
\hline $1: 00$ & $-3: 00$ & $\begin{array}{l}\text { Presentations by Discussion } \\
\text { Group Chairpersons ( } 30 \\
\text { minutes each) }\end{array}$ & $\begin{array}{l}\text { Wayne H. Smith, } \\
\text { To be Determined, } \\
\text { Carel Otte, and } \\
\text { Samuel Fleming }\end{array}$ \\
\hline $3: 00$ & $-\quad 3: 45$ & $\begin{array}{l}\text { Adjourn and return to } \\
\text { Hilltop House }\end{array}$ & Phyllis J. Marte11 \\
\hline $3: 15$ & $-\quad 4: 15$ & DOE Executive Staff Review & A11 DOE Personnel \\
\hline $4: 15$ & $-4: 30$ & $\begin{array}{l}\text { DOE personnel return to } \\
\text { Hilltop House }\end{array}$ & Phyllis J. Martell \\
\hline
\end{tabular}

OCTOBER 17

A tour of the Hot Dry Rock Project will be held this morning. Contact Mike Berger at (505) 667-3973, Los Alamos National Laboratory, if you want to take the tour. It will take about 4 hours. 
GEOTHERMAL BRIEFING OUTLINE

October 15,1986

Los Alamos National Laboratory

$$
\text { 9:15- 9:45 Introduction and overview }
$$

HYDROTHERMAL RESOURCES PROGRAM

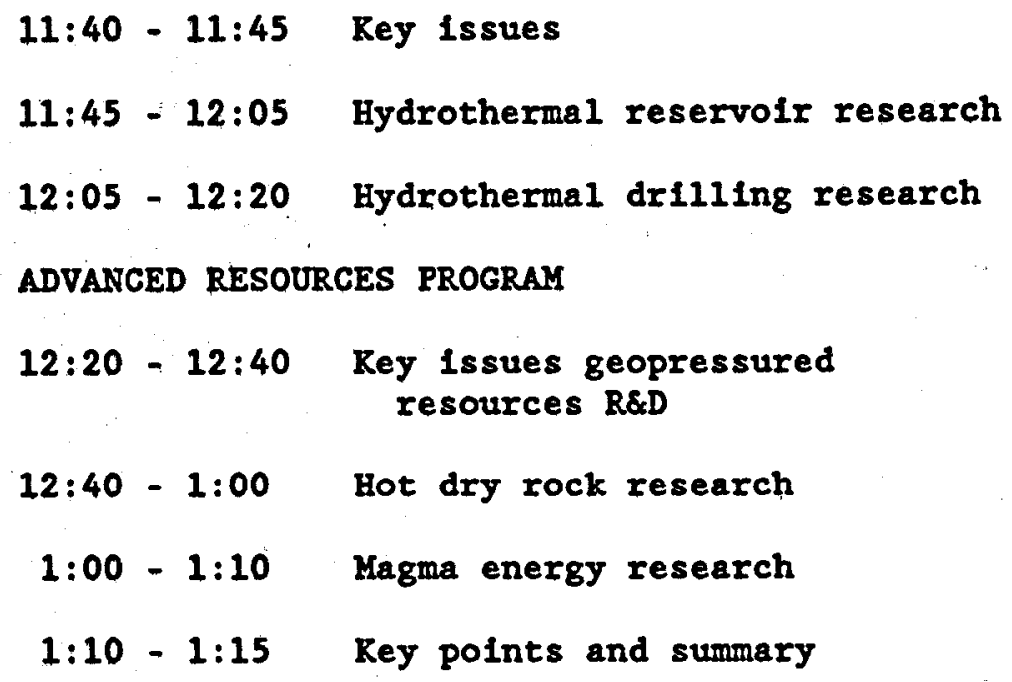

John Mock, DOE

John Mock, DOE

Clay Nichols, IDO

Dick Traeger, Sandia

James Bresee, DOE

John Whetten, IANL

Dick Traeger, Sandia

John Kock, DOE 
$91 / 92$

BIOFUELS AND MUNICIPAL WASTE

BRIEFING OUTLINE

October 15, 1986

Los Alamos National Laboratory

8:45 - 9:15 Introduction and overview Donald Walter, DOE

GROWTH TECHNOLOGIES

$\begin{array}{rll}9: 55-10: 25 & \text { Terrestrial } & \text { Robert Van Hook, ORNL } \\ 10: 25-10: 35 & \text { Aquatics } & \text { Stanley Bull, SERI }\end{array}$

CONVERSION TECHNOLOGIES

Blochemical Conversion

$10: 35-10: 55$ Iiquid fuels

Stanley Bull, SERI

10:55 - 11:05 Gaseous fuels

Stanley Bull, SERI

Thermochemical Conversion
11:05 - 11:10 Municipal waste
Stanley Bull, SERI
11:10 - 11:25 B1ofuels
Gary Schiefelbein, PNL
$11: 25-11: 30$ Key 1ssues and summary
Donald Walter, DOE 


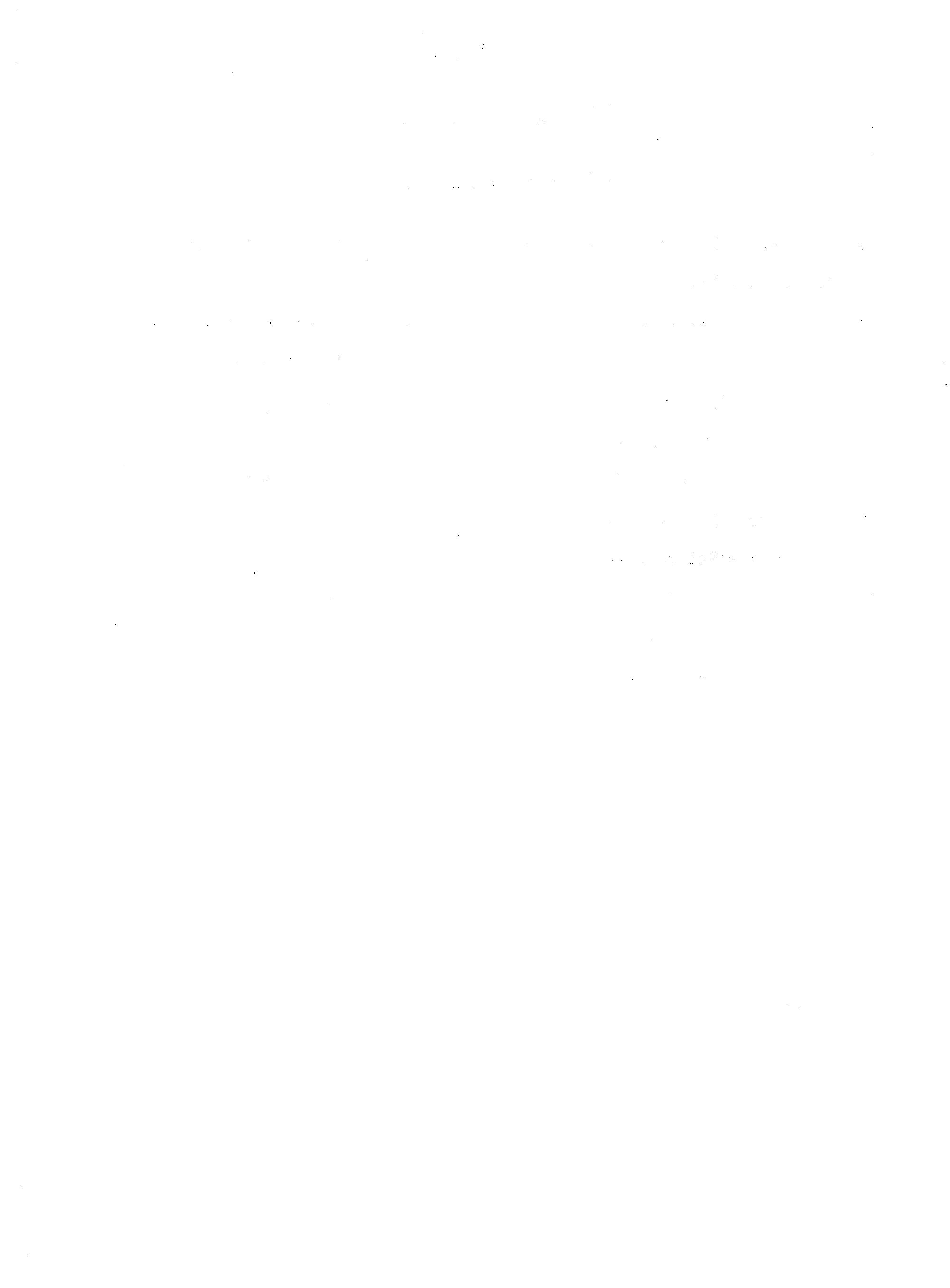




\section{APPENDIX H}

\section{UNIT CONVERSION TABLE}

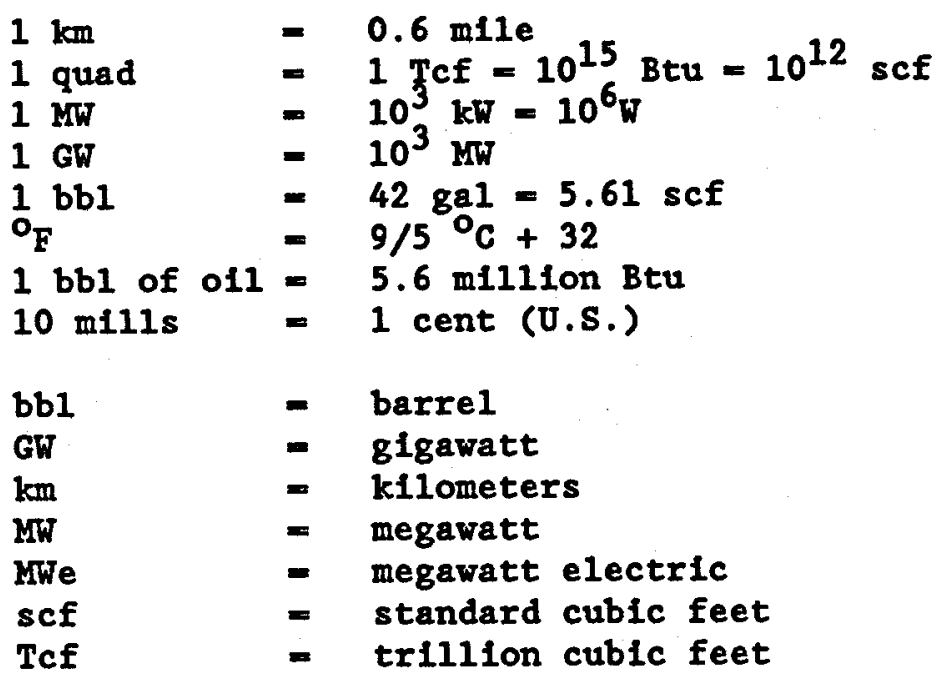





\section{REFERENCES}

Armstead, H. C. H., and J. W. Tester. 1987. Heat Mining.

London: E. F. Spon, 460 Pp.

Batchelor, A. S. 1984. Hot dry rock geothermal exploitation in the United Kingdom. Modern Geology 9:1-41.

California Energy Commission. 1985. Relative Cost of Electricity Production. (July). Sacramento, California.

Carson, C. C., and J. Haraden. 1985. The economics of magma power generation. Geothermal Resources Counc1l Transaction 9:171-175.

Colp, J. L. . 1982. Final Report--Magma Energy Research Project, Sandia Report SAND82-2377, Sandia National Laboratorles, Albuquerque, New Mexico $87185,36 \mathrm{pp}$.

Dash, Z. V., et al. 1983. Hot dry rock geothermal reservoir testing 1978-1980. J. of Volcanology and Geothermal Research 15:59-99.

DIPIppo, R. 1986. Geothermal power plants, worldwide status, 1986. Geothermal Resources Council Bulletin 11:9-18 (December). Davis, California.

DOE (U.S. Department of Energy). 1986. U.S. Geothermal Energy Program, Five-Year Research Program 1986-1990 (draft). Washington, D.C.

DOE (U.S. Department of Energy). 1987. Energy Security. A Report to the President of the United States (March). Washington, D.C.

Dunn, J. C., A. Ortega, C. E. Hickox, T. Y. Chu, R. P. Wempole, and R. F. Boehm. 1987. Magma Energy Extraction, in Twelfth Workshop on Geothermal Reservoir Engineering, Stanford University, Stanford, California 94305, preprint, 8 pp.

Gray, E. E., and R. T. Lorand. 1986. Overview of R\&D Cooperative Concepts for Solar Buildings. Report prepared for Solar Energy Research Institute, August 26.

Hardee, H. C., J. C. Dunn, R. G. Hills, and R. W. Ward. 1981. Probing the melt zone of Kilauea Iki Lava Lake, Kilauea Volcano, Hawa11, Geophy. Res. Lett. $8: 1,211-1,214$.

Hirsch, R. L. 1987. Impending United States energy crisis. Science $235: 1,467-1,473$.

Hot Dry Rock Assessment Pane1 (HDRAP). 1977. Hot Dry Rock Geothermal Energy--Status of Exploration and Assessment, Report 1, June 1977, Energy Research and Development Administration, ERDA-77-74; Washington, D.C. 
Kestin, J., R. DiPippo, H. E. Khalifa, and D.J. Ryley (editors). 1980. Sourcebook for the Production of Electricity from Geothermal Energy. U.S. Government Printing Office. Washington, D.C.

Kron, A., and G. Heiken. 1980. Geothermal gradient map of the coterminous U.S., Los Alamos Laboratory, Los Alamos, New Mexico. (LA-8476-MAP).

Muffler, L. J. P., ed. 1979. Assessment of Geothermal Resources of the United States--1978, O.S. Geological Survey Circular 790. Reston, Virginia.

National Research Council. 1986a. New Alliances and Partnerships in American Science and Engineering. Proceedings of a conference held December 5, 1985, Government-University-Industry Research Roundtable. National. Academy Press. Washington, D.C.

National Research Council. 1986b. The New Engineering Research Centers: Purposes, Goals, and Expectations. Proceedings of a symposium held April 29-30, 1985, Commission on Engineering and Technical Systems, National Research Council. National Academy Press. Washington, D.C.

North American Electric Rellability Council. Equipment Avallability Reports. Issued annually. Princeton, New Jersey.

Peters, L.S. and H. Fusfeld. 1986. Research and Development Iimited Partnerships and Their Significance for Innovation. Center for Science and Technology Policy. Rennselaer Polytechnic Institute (Apri1).

Reed, M.J. 1983. Assessment of Low Temperature Geothermal Resources of the United States. U.S. Geological Survey Circular 892. Reston, virginia.

Rowley, J. C. 1982. Worldwide Geothermal Resources, Chapter 2 in Handbook of Geothermal Energy, G. V. Chilingar et al. eds. Gulf Publishing, Houston, Texas.

Shock, R. A. W. 1986. An Economic Assessment of Hot Dry Rocks as an Energy Source for the U.R. Energy Technology Support Unit (ETSU), Report R34, AERE. Herwe11, U.R.

Smith, H. C., R. L. Aamodt, R. M. Potter, and D. W. Brown. 1975. Man-made geothermal reservoirs, Proceedings of the 2nd un Symposium on Geothermal Energy, San Francisco, California, pp. 181-1,787.

Smith, R. L., and H. R. Shaw. 1979. Igneous-Related Geothermal Systems. In Assessment of Geothermal Resources of the United States--1978. U.S. Geological Survey Circular 790, pp. 12-17. Reston, Virginia.

USGS (U.S. Geological Survey). 1979. Assessment of Geothermal Resources of the United States--1978. Circular 790. Reston, Virginia. 
Whetten, J., et al. 1986. The U.S. Hot Dry Rock Project, Los Alamos National Laboratory Report LA-UR 86-1109. Presented at EEC/U.S. Workshop on Geothermal Hot Dry Rock, Brussels, Belgium, May 28-30, 1986.

White, D. F., and D. L. Williams. 1975. Assessment of Geothermal Resources of the United States--1975. U.S. Geological Survey Circular 726. Reston, Virginia. 